\title{
Functional choline phosphate lipids for enhanced drug delivery in cancer therapy
}

Wenliang Wang ${ }^{*, \star}$, Sangni Jiang ${ }^{\dagger, \S}$, Shengran $\mathrm{Li}^{\dagger}, \S$, XinXin Yan ${ }^{\dagger, \S}$, Sanrong $\mathrm{Liu}^{*}, \overline{,}$, Xiaobo Mao ${ }^{*,+}$, Xifei $\mathrm{Yu}^{*}, \dagger, \&$

$\dagger$ Laboratory of Polymer Composites Engineering, Changchun Institute of Applied Chemistry, Chinese Academy of Sciences, Changchun, Jilin 130022, P.R. China.

¥ Institute for Cell Engineering, Johns Hopkins University School of Medicine, Baltimore, MD 21205, USA

$\S$ University of Science and Technology of China, Hefei, Anhui 230026 China 


\section{Contents}

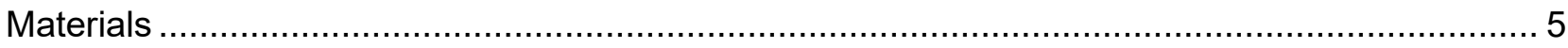

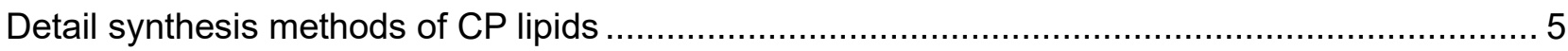

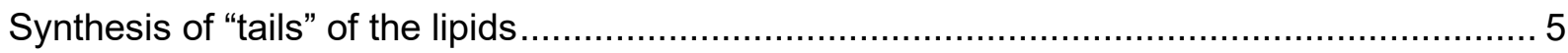

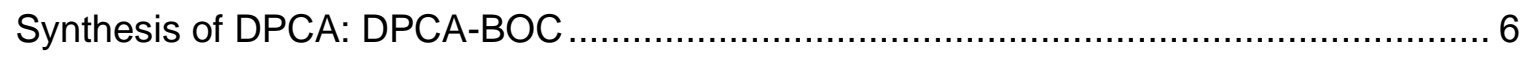

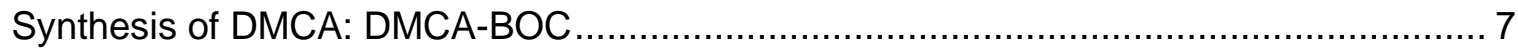

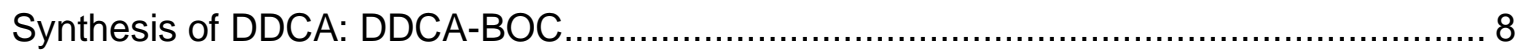

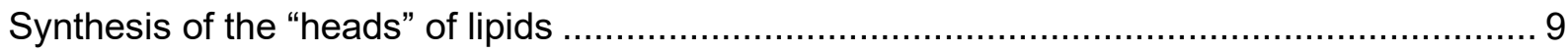

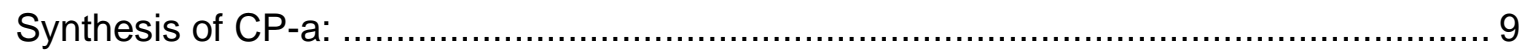

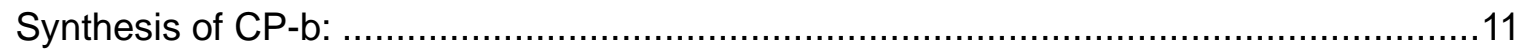

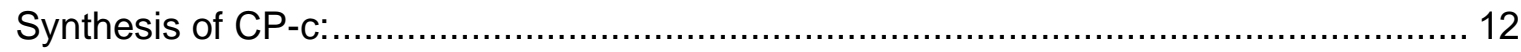

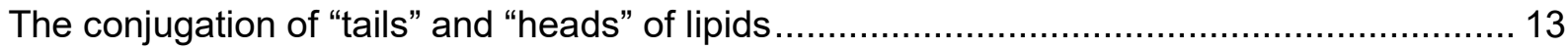

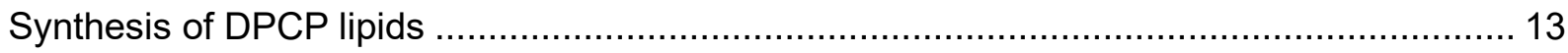

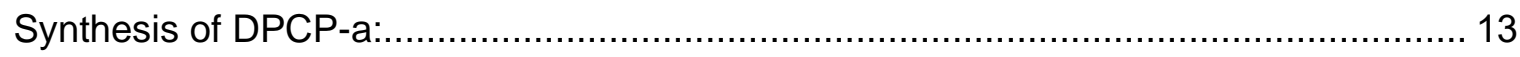

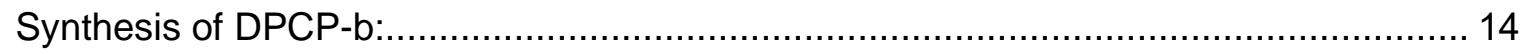

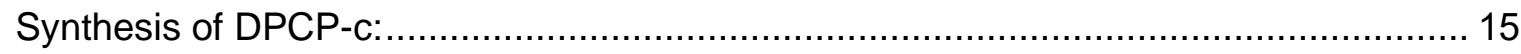

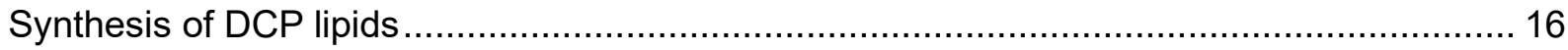

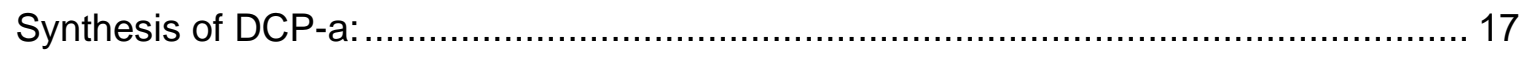

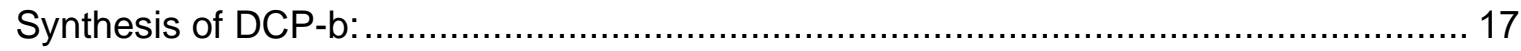

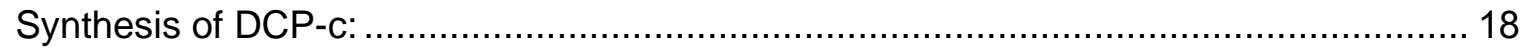


Synthesis of DDCP lipids

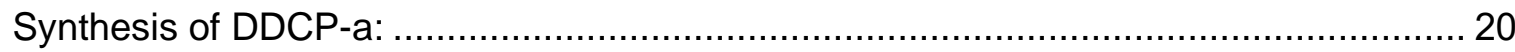

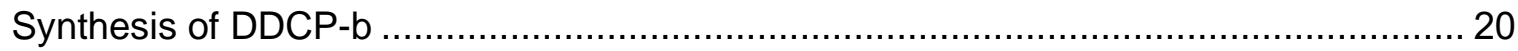

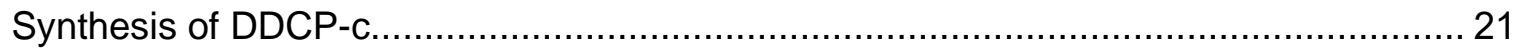

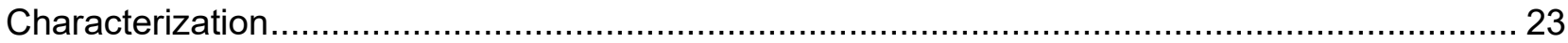

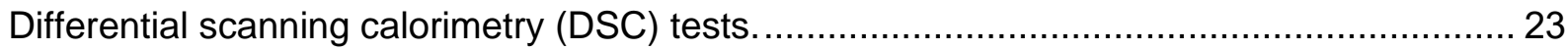

Preparation of the choline phosphate liposomes and determination of DLE and DLC......... 24

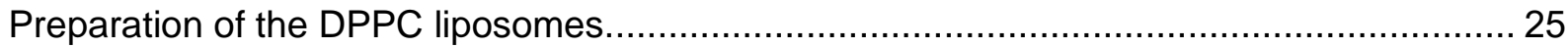

Dependence of zeta potential and size of liposomes on variation in $\mathrm{pH}$............................ 26

Dependence of zeta potential and size of liposomes on variation in $\mathrm{NaCl}$ concentrations .... 26

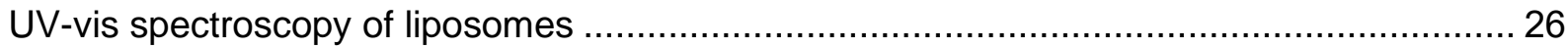



In vivo biocompatibility assessment via blood biochemistry and hematology of mice .......... 27

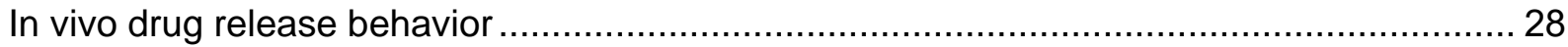

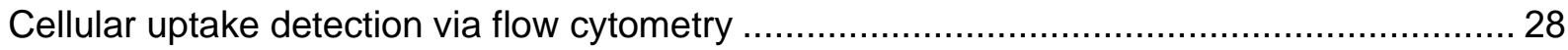

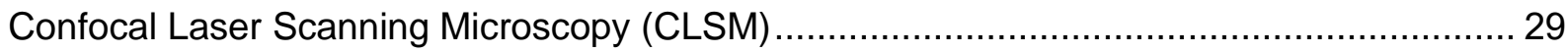



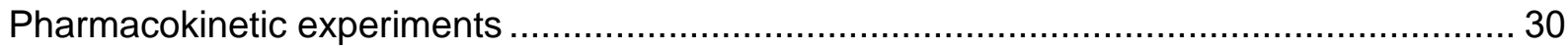

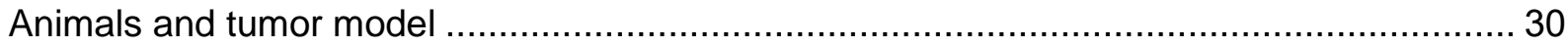

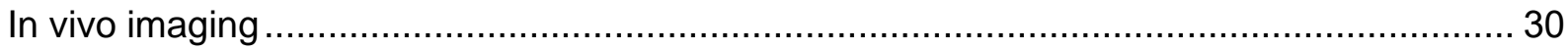

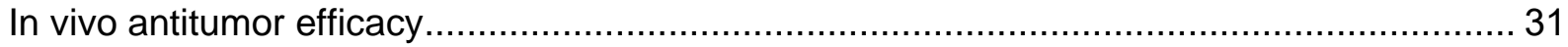




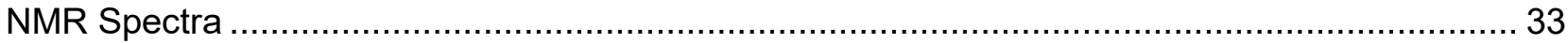

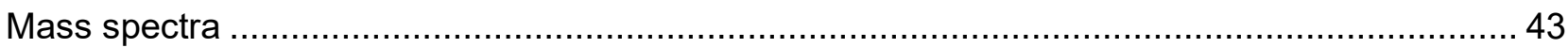

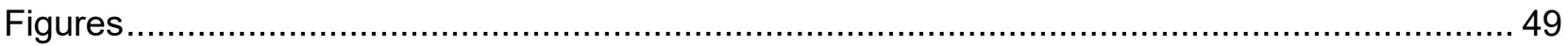

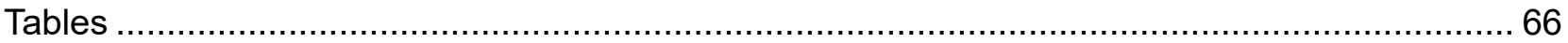

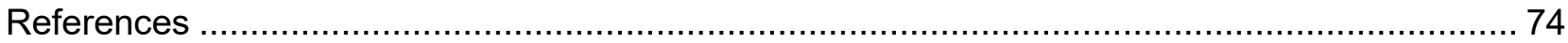




\section{Materials}

Palmitic acid (PA), myristic acid (MA), dodecanoic acid (DA), 3-diisopropylcarbodiimide (DIC), dimethylaminopyridine (DMAP), trifluoroacetic acid (TFA), 2-chloro-2-oxo-1,3,2dioxaphospholane, 2-(dimethylamino)ethyl methacrylate, butylated hydroxytoluene (BHT) were purchased from Aladdin. Folate-PEG-azide (molecular weight: 1000) was purchase from Ponsure Bio, Inc. (China, shanghai). Butyl alcohol, 3-buten-1-ol, 3-butyn-1-ol were purchased from TCl Tert-Butyl N-(2,3-dihydroxypropyl) carbamate was purchased from Energy Chemical. Dichloromethane, acetonitrile was dried over $\mathrm{CaH}_{2}$ for $48 \mathrm{~h}$ and distilled under vacuum before use.

\section{Detail synthesis methods of CP lipids}

\section{Synthesis of "tails" of the lipids}

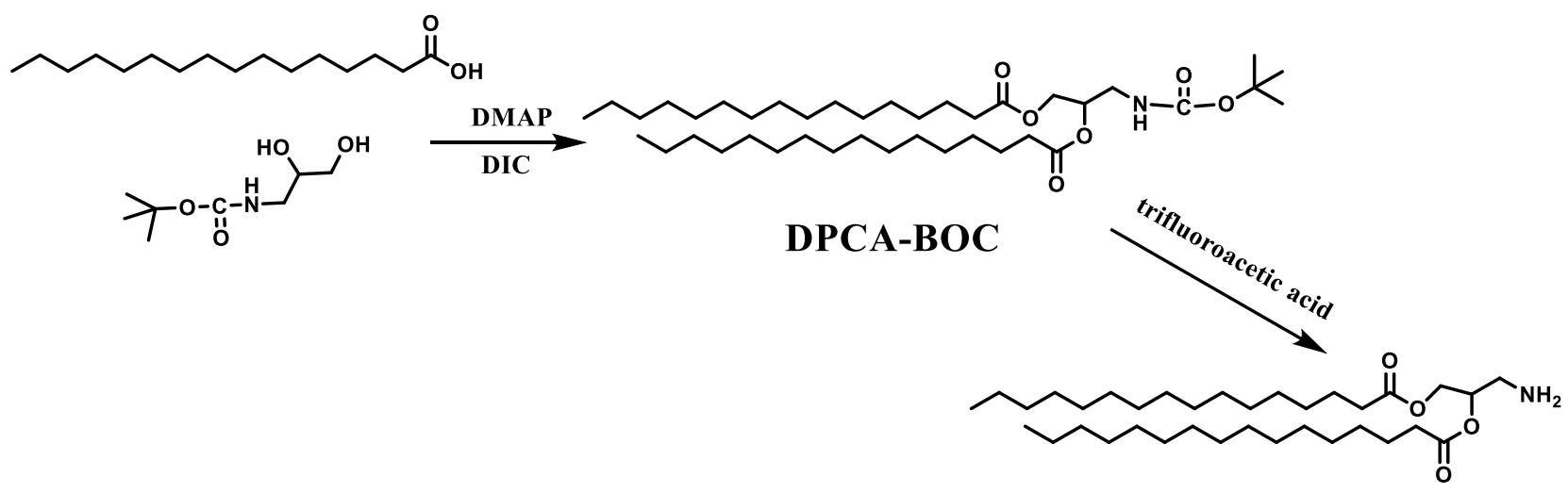

DPCA

Scheme 1: The detail of synthesis of DPCA. 
Synthesis of DPCA: DPCA-BOC was synthesized at first. Palmitic acid $(2.3 \mathrm{mmol}, 0.60 \mathrm{~g})$, tert-Butyl N-(2,3-dihydroxypropyl) carbamate $(1.0 \mathrm{mmol}, 0.19 \mathrm{~g})$, DMAP $(0.2 \mathrm{mmol}, 25 \mathrm{mg})$ and DIC (2.3 mmol, $0.29 \mathrm{~g})$ were dissolved in dichloromethane $\left(20 \mathrm{~mL}\right.$, dried via $\mathrm{CaH}_{2}$ before use). After stirred at room temperature for $24 \mathrm{~h}$, the solution was filtered to remove the precipitate, and the filtrate was dried by rotary evaporation. Finally, the residue was purified by silica column chromatography with a mixture of petroleum ether/ethyl acetate $(3 / 1, v / v)$. The product was obtained via removing the solution with yield $93.5 \% .{ }^{1} \mathrm{H}$ NMR (500MHz, $\left.\mathrm{CDCl}_{3}\right): \delta(\mathrm{ppm}) 5.09$ (m, -OCH( $\left.\left.\mathrm{CH}_{2} \mathrm{O}-\right) \mathrm{CH}_{2} \mathrm{~N}-\right)$, 4.73 (s, -NH-BOC), 4.26, 4.16 $\left(\mathrm{m}, \quad-\mathrm{OOCH} \mathrm{H}_{2} \mathrm{CH}-\right), \quad 3.35$ (m, $\left.-\mathrm{NH}-\mathrm{CH}_{2}-\mathrm{CH}-\right), \quad 2.31\left(\mathrm{~m},-\mathrm{CH}_{2} \mathrm{CH}_{2} \mathrm{COO}-\right), \quad 1.62(\mathrm{~m}, \quad-$ $\left.\mathrm{CH}_{2} \mathrm{CH}_{2} \mathrm{COO}-\right), 1.44\left(\mathrm{~s}, \mathrm{CH}_{3}, \mathrm{BOC}\right), 1.25\left(\mathrm{~m}, \mathrm{CH}_{3} \mathrm{CH}_{2}-\right), 0.88\left(\mathrm{~m}, \mathrm{CH}_{3} \mathrm{CH}_{2-}\right)$.
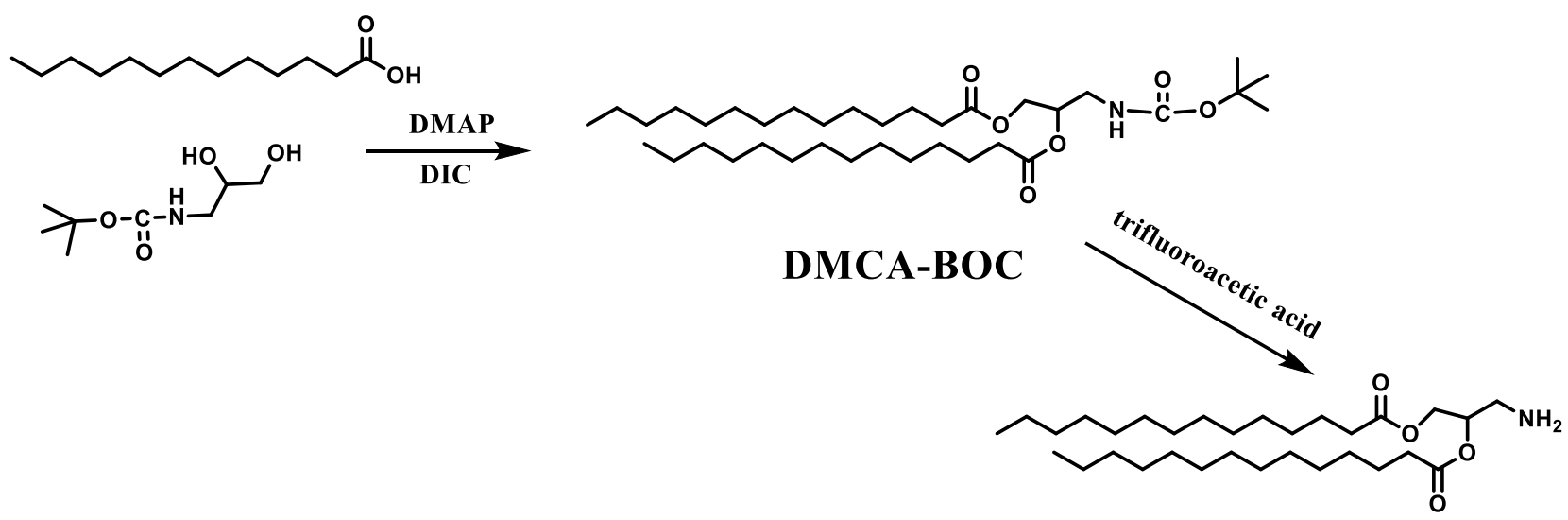

DMCA

\section{Scheme 2: The detail of synthesis of DMCA.}

Secondly, DPCA-BOC (1.20g) was dissolved in dichloromethane $\left(20 \mathrm{~mL}\right.$, dried via $\mathrm{CaH}_{2}$ before use), and then the TFA ( $5 \mathrm{~mL}$ ) was added. After stirred at room temperature for $4 \mathrm{~h}$, 
the solution was dried by rotary evaporation. Finally, the residue was washed three times via diethyl ether. The product DPCA was obtained via removing the solution with yield 97.6\%. ${ }^{1} \mathrm{H}$ NMR (500MHz, d $\mathrm{d}_{6}$-DMSO): $\delta(\mathrm{ppm}) 7.95\left(-\mathrm{NH}_{2}\right), 5.17\left(\mathrm{~m},-\mathrm{OC} \boldsymbol{H}\left(\mathrm{CH}_{2} \mathrm{O}-\right) \mathrm{CH}_{2} \mathrm{~N}-\right)$, 4.31, 4.04 (m, - $\left.-\mathrm{OOCH}_{2} \mathrm{CH}-\right), 3.14,3.01$ (m, $\left.\mathrm{NH}_{2}-\mathrm{CH}_{2}-\mathrm{CH}-\right), 2.27\left(\mathrm{~m},-\mathrm{CH}_{2} \mathrm{CH}_{2} \mathrm{COO}-\right)$, 1.23(m, $\left.\mathrm{CH}_{3} \mathrm{CH}_{2}\right), 0.85\left(\mathrm{~m}, \mathrm{CH}_{3} \mathrm{CH}_{2}-\right)$. HR-ESI-mass spectrum calculated for $\mathrm{C} 35 \mathrm{H} 69 \mathrm{NO} 4$ 567.94, found $568.53(\mathrm{M}+\mathrm{H}), 590.51(\mathrm{M}+\mathrm{Na})$.

Synthesis of DMCA: DMCA-BOC was synthesized at first. Myristic acid (2.3 mmol, $0.53 \mathrm{~g})$, tert-Butyl $\mathrm{N}$-(2,3-dihydroxypropyl) carbamate $(1.0 \mathrm{mmol}, 0.19 \mathrm{~g})$, DMAP $(0.2 \mathrm{mmol}, 25 \mathrm{mg})$ and DIC (2.3 mmol, $0.29 \mathrm{~g})$ were dissolved in dichloromethane $(20 \mathrm{~mL})$. After stirred at room temperature for $24 \mathrm{~h}$, the solution was filtered to remove the precipitate, and the filtrate was dried by rotary evaporation. Finally, the residue was purified by silica column chromatography with a mixture of petroleum ether/ethyl acetate $(4 / 1, \mathrm{v} / \mathrm{v})$. The product was obtained via removing the solution with yield $98.6 \% .{ }^{1} \mathrm{H} \mathrm{NMR}\left(500 \mathrm{MHz}, \mathrm{CDCl}_{3}\right): \delta(\mathrm{ppm})$ 5.09 (m, - $\left.\mathrm{OCH}\left(\mathrm{CH}_{2} \mathrm{O}-\right) \mathrm{CH}_{2} \mathrm{~N}-\right), 4.75$ (s, -NH-BOC), 4.25, 4.15 (m, -OOCH $\left.\mathrm{NH}-\mathrm{CH}_{2}-\mathrm{CH}-\right), 2.32\left(\mathrm{~m},-\mathrm{CH}_{2} \mathrm{CH}_{2} \mathrm{COO}-\right), 1.62\left(\mathrm{~m},-\mathrm{CH}_{2} \mathrm{CH}_{2} \mathrm{COO}-\right), 1.43\left(\mathrm{~s}, \mathrm{CH}_{3}, \mathrm{BOC}\right)$, $1.26\left(\mathrm{~m}, \mathrm{CH}_{3} \mathrm{CH}_{2-}\right), 0.88\left(\mathrm{~m}, \mathrm{CH}_{3} \mathrm{CH}_{2}-\right)$.

Then, DMCA-BOC (1.20g) was dissolved in dichloromethane $\left(20 \mathrm{~mL}\right.$, dried via $\mathrm{CaH}_{2}$ before use), and then the TFA ( $5 \mathrm{~mL}$ ) was added. After stirred at room temperature for $4 \mathrm{~h}$, the solution was dried by rotary evaporation. Finally, the residue was washed three times via diethyl ether. The product DMCA was obtained via removing the solution with yield 
97.9\%. ${ }^{1} \mathrm{H}$ NMR (500MHz, d6-DMSO): $\delta(p p m) 7.94\left(-\mathrm{NH}_{2}\right), 5.17\left(\mathrm{~m},-\mathrm{OC} \boldsymbol{H}\left(\mathrm{CH}_{2} \mathrm{O}-\right) \mathrm{CH}_{2} \mathrm{~N}-\right)$, 4.33, 4.03 (m, - $\left.-\mathrm{OOCH}_{2} \mathrm{CH}-\right), 3.13,3.01$ (m, $\left.\mathrm{NH}_{2}-\mathrm{CH}_{2}-\mathrm{CH}-\right), 2.26\left(\mathrm{~m},-\mathrm{CH}_{2} \mathrm{CH}_{2} \mathrm{COO}-\right)$, 1.23(m, $\left.\mathrm{CH}_{3} \mathrm{CH}_{2-}\right), 0.85\left(\mathrm{~m}, \mathrm{CH}_{3} \mathrm{CH}_{2}-\right)$. ESI-mass spectrum calculated for $\mathrm{C} 31 \mathrm{H} 61 \mathrm{NO} 4$ 511.8 , found $512.8(\mathrm{M}+\mathrm{H})$.

Synthesis of DDCA: DDCA-BOC was synthesized at first. Dodecanoic acid $(2.3 \mathrm{mmol}, 0.46$ g), tert-Butyl $N$-(2,3-dihydroxypropyl) carbamate $(1.0 \mathrm{mmol}, 0.19 \mathrm{~g})$, DMAP $(0.2 \mathrm{mmol}, 25$ $\mathrm{mg})$ and DIC (2.3 mmol, $0.29 \mathrm{~g})$ were dissolved in dichloromethane $(20 \mathrm{~mL})$. After stirred at room temperature for $24 \mathrm{~h}$, the solution was filtered to remove the precipitate, and the filtrate was dried by rotary evaporation. Finally, the residue was purified by silica column chromatography with a mixture of petroleum ether/ethyl acetate $(5 / 1, \mathrm{v} / \mathrm{v})$. The product was obtained via removing the solution with yield $94.2 \% .{ }^{1} \mathrm{H} \mathrm{NMR}\left(500 \mathrm{MHz}, \mathrm{CDCl}_{3}\right): \delta(\mathrm{ppm})$ $5.11\left(\mathrm{~m},-\mathrm{OC} \boldsymbol{H}\left(\mathrm{CH}_{2} \mathrm{O}-\right) \mathrm{CH}_{2} \mathrm{~N}-\right), 4.73(\mathrm{~s},-\mathrm{NH}-\mathrm{BOC}), 4.27,4.16\left(\mathrm{~m},-\mathrm{OOCH} \mathrm{H}_{2} \mathrm{CH}-\right), 3.36(\mathrm{~m},-$ $\left.\mathrm{NH}-\mathrm{CH}_{2}-\mathrm{CH}-\right), 2.31\left(\mathrm{~m},-\mathrm{CH}_{2} \mathrm{CH}_{2} \mathrm{COO}-\right), 1.63\left(\mathrm{~m},-\mathrm{CH}_{2} \mathrm{CH}_{2} \mathrm{COO}-\right), 1.44\left(\mathrm{~s}, \mathrm{CH}_{3}, \mathrm{BOC}\right)$, $1.25\left(\mathrm{~m}, \mathrm{CH}_{3} \mathrm{CH}_{2^{-}}\right), 0.86\left(\mathrm{~m}, \mathrm{CH}_{3} \mathrm{CH}_{2}\right)$.

Then, DDCA-BOC (1.20g) was dissolved in dichloromethane $\left(20 \mathrm{~mL}\right.$, dried via $\mathrm{CaH}_{2}$ before use), and then the TFA ( $5 \mathrm{~mL}$ ) was added. After stirred at room temperature for $4 \mathrm{~h}$, the solution was dried by rotary evaporation. Finally, the residue was washed three times via diethyl ether. The product DDCA was obtained via removing the solution with yield 95.5\%. ${ }^{1} \mathrm{H}$ NMR (500MHz, $\left.\mathrm{d}_{6}-\mathrm{DMSO}\right): \delta(\mathrm{ppm}) 7.96\left(-\mathrm{NH}_{2}\right), 5.16\left(\mathrm{~m},-\mathrm{OCH}\left(\mathrm{CH}_{2} \mathrm{O}-\right) \mathrm{CH}_{2} \mathrm{~N}-\right)$, 4.32, 4.05 (m, - $\left.\mathrm{OOCH} \mathrm{H}_{2} \mathrm{CH}-\right), 3.14,3.02\left(\mathrm{~m}, \mathrm{NH}_{2}-\mathrm{CH}_{2}-\mathrm{CH}-\right)$, 2.25(m, $\left.-\mathrm{CH}_{2} \mathrm{CH}_{2} \mathrm{COO}-\right)$, 
1.22( $\left.\mathrm{m}, \mathrm{CH}_{3} \mathrm{CH}_{2}-\right), 0.87\left(\mathrm{~m}, \mathrm{CH}_{3} \mathrm{CH}_{2}-\right)$. ESI-mass spectrum calculated for $\mathrm{C} 27 \mathrm{H} 53 \mathrm{NO} 4$ 455.7, found $456.7(\mathrm{M}+\mathrm{H}), 478.4(\mathrm{M}+\mathrm{Na})$.
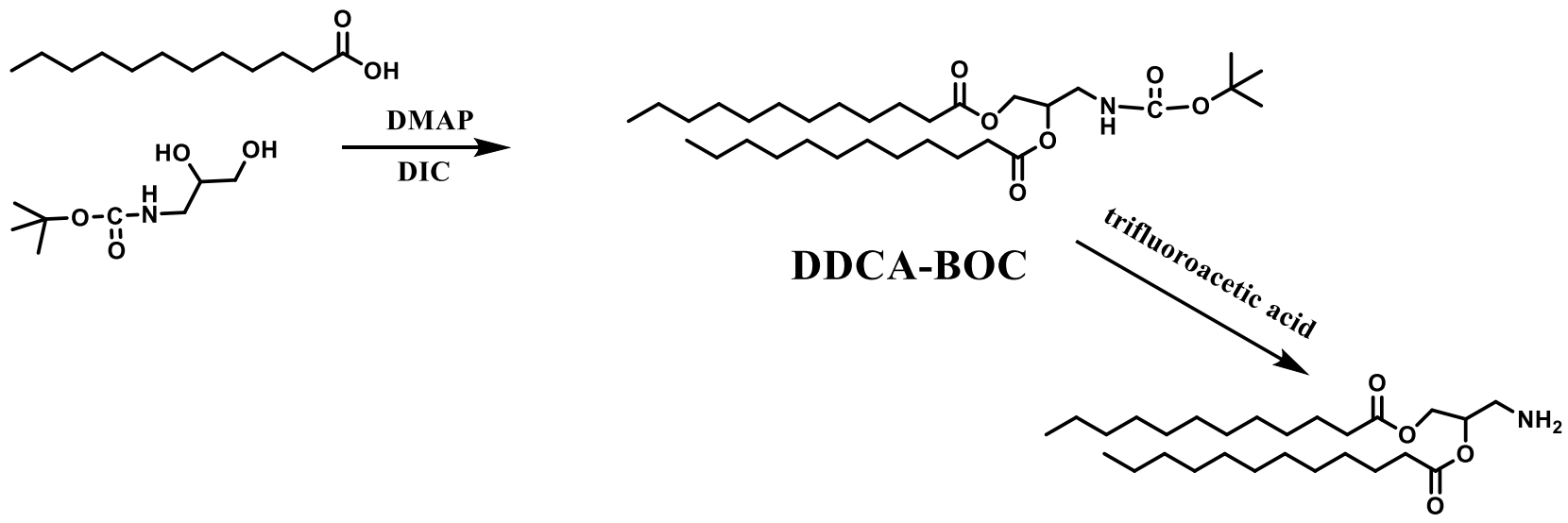

DDCA

Scheme 3: The detail of synthesis of DDCA.

Synthesis of the "heads" of lipids

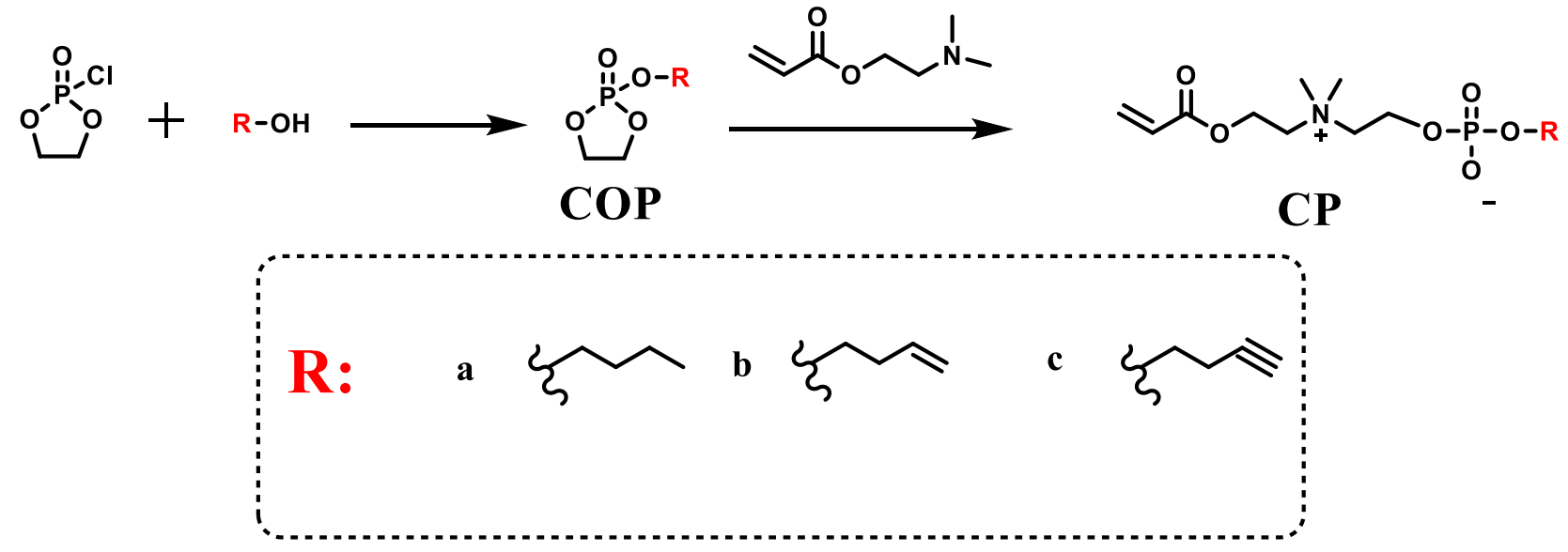

Scheme 4: The detail of synthesis of "head" of lipid a remix of CP.

Synthesis of CP-a: CP was synthesized based on our previous method, and made some improvement. In brief, the COP-a was synthesized at first. All glassware was flam dried 
and protected by argon before using. Butyl alcohol $(0.1 \mathrm{~mol}, 7.41 \mathrm{~g})$ prepared via distilling $\mathrm{CaH}_{2}$ mixed solution, 2-chloro-2-oxo-1,3,2-dioxaphospholane $(0.1 \mathrm{~mol}, 14.21 \mathrm{~g})$, and THF (150 mL, dried via $\mathrm{Na}$ and distilled freshly before using) were added to $250 \mathrm{~mL}$ Schlenk flask under the argon protection. The solution was stirred and cooled to $-78^{\circ} \mathrm{C}$. Then, the triethylamine $\left(0.11 \mathrm{~mol}, 11.11 \mathrm{~g}\right.$, dried via $\mathrm{CaH}_{2}$ and distilled freshly before using) was added dropwise about $2 \mathrm{~h}$, and the solution was reacted at room temperature for another $4 \mathrm{~h}$. After that, the solution was cooled to $-40^{\circ} \mathrm{C}$ to filter off the white precipitate, the filtrate was directly distilled at Schlenk flask, where the whole process was conducted under argon atmosphere. Finally, the obtained liquid was purified via vacuum distillation, and the COPa was collected with yield 76.4\%. ${ }^{1} \mathrm{H} \mathrm{NMR}\left(500 \mathrm{MHz}, \mathrm{CDCl}_{3}\right)$ : 4.44-4.35 (m, $\left.-\mathrm{OCH}_{2} \mathrm{CH}_{2} \mathrm{O}-\right)$, $4.15\left(\mathrm{~m},-\mathrm{OCH}_{2} \mathrm{CH}_{2} \mathrm{CH}_{2} \mathrm{CH}_{3}\right), 1.67\left(\mathrm{~m},-\mathrm{OCH}_{2} \mathrm{CH}_{2} \mathrm{CH}_{2} \mathrm{CH}_{3}\right), 1.41$ (m, $\left.-\mathrm{OCH}_{2} \mathrm{CH}_{2} \mathrm{CH}_{2} \mathrm{CH}_{3}\right)$, $0.93\left(\mathrm{t},-\mathrm{OCH}_{2} \mathrm{CH}_{2} \mathrm{CH}_{2} \mathrm{CH}_{3}\right) ;{ }^{31} \mathrm{P} \mathrm{NMR}\left(500 \mathrm{MHz}, \mathrm{CDCl}_{3}\right)$ : $\delta(\mathrm{ppm}) 17.60$ (s).

Secondly, the CP-a was synthesized via ring-opening reaction. All glassware was flam dried and protected by argon before using. Briefly, COP-a $(0.03 \mathrm{~mol}, 5.41 \mathrm{~g})$, 2(dimethylamino) ethyl acrylate, and BHT (100 mg) were added to $50 \mathrm{~mL}$ acetonitrile (dried via $\mathrm{Na}$ and distilled freshly before using). The reaction was conducted at $70{ }^{\circ} \mathrm{C}$ for $56 \mathrm{~h}$, and then the solution was precipitated three times via THF, after removed the THF, the CPa was obtained with yield $89.7 \% .{ }^{1} \mathrm{H}$ NMR $\left(500 \mathrm{MHz}, \mathrm{D}_{2} \mathrm{O}\right.$ ): 6.43 and 6.21 (d and $\mathrm{m}$, $\left.\mathrm{OCCH}=\mathrm{CH}_{2}\right), 6.03\left(\mathrm{~d},-\mathrm{OCCH}=\mathrm{CH}_{2}\right), 4.64$ (t, $\left.-\mathrm{CH}_{2} \mathrm{O}-\mathrm{CO}-\right), 4.29\left(\mathrm{t},-\mathrm{CH}_{2} \mathrm{OP}\right), 3.86(\mathrm{~m},-$ $\left.\mathrm{CH}_{2} \mathrm{~N}\left(\mathrm{CH}_{3}\right)_{2}-\mathrm{CH}_{2-}\right), 3.74\left(\mathrm{~d}, \mathrm{P}-\mathrm{OCH}_{2}-\mathrm{CH}_{2}-\right), 3.25\left(\mathrm{~s},-\mathrm{N}-\left(\mathrm{CH}_{3}\right)_{2}\right), 1.58\left(\mathrm{~m}, \mathrm{P}-\mathrm{OCH}_{2}-\mathrm{CH}_{2}-\right.$ 
$\left.\mathrm{CH}_{2}-\mathrm{CH}_{3}\right), \quad 1.35\left(\mathrm{~m}, \mathrm{P}-\mathrm{OCH}_{2}-\mathrm{CH}_{2}-\mathrm{CH}_{2}-\mathrm{CH}_{3}\right), \quad 0.88\left(\mathrm{~m}, \mathrm{P}-\mathrm{OCH}_{2}-\mathrm{CH}_{2}-\mathrm{CH}_{2}-\mathrm{CH}_{3}\right) ;{ }^{31} \mathrm{P} \quad \mathrm{NMR}$ (500MHz, $\left.\mathrm{D}_{2} \mathrm{O}\right): \delta(\mathrm{ppm}) 0.06(\mathrm{~s})$.

Synthesis of CP-b: In brief, the COP-b was synthesized at first. All glassware was flam dried and protected by argon before using. 3-Buten-1-ol $(0.1 \mathrm{~mol}, 7.21 \mathrm{~g})$ prepared via distilling $\mathrm{CaH}_{2}$ mixed solution, 2-chloro-2-oxo-1,3,2-dioxaphospholane $(0.1 \mathrm{~mol}, 14.21 \mathrm{~g})$, and THF(150 mL, dried via Na and distilled freshly before using) were added to $250 \mathrm{~mL}$ Schlenk flask under the argon protection. The solution was stirred and cooled to $-78^{\circ} \mathrm{C}$. Then, the triethylamine $\left(0.11 \mathrm{~mol}, 11.11 \mathrm{~g}\right.$, dried via $\mathrm{CaH}_{2}$ and distilled freshly before using) was added dropwise about $2 \mathrm{~h}$, and the solution was reacted at room temperature for another $4 \mathrm{~h}$. After that, the solution was cooled to $-40^{\circ} \mathrm{C}$ to filter off the white precipitate, the filtrate was directly distilled at Schlenk flask, where the whole process was conducted under argon atmosphere. Finally, the obtained liquid was purified via vacuum distillation, and the COPb was collected with yield $79.8 \% .{ }^{1} \mathrm{H}$ NMR $\left(500 \mathrm{MHz}, \mathrm{CDCl}_{3}\right): 5.79\left(\mathrm{~m},-\mathrm{OCH}_{2}-\mathrm{CH}_{2}{ }^{-}\right.$ $\left.\mathrm{CH}=\mathrm{CH}_{2}\right), 5.17\left(\mathrm{~m},-\mathrm{OCH}_{2}-\mathrm{CH}_{2}-\mathrm{CH}=\mathrm{CH}_{2}\right), 4.45-4.37\left(\mathrm{~m},-\mathrm{OCH}_{2} \mathrm{CH}_{2} \mathrm{O}-\right), 4.18(\mathrm{~m},-$ $\left.\mathrm{OCH}_{2} \mathrm{CH}_{2} \mathrm{CH}=\mathrm{CH}_{2}\right), 2.45\left(\mathrm{~m},-\mathrm{OCH}_{2} \mathrm{CH}_{2} \mathrm{CH}=\mathrm{CH}_{2}\right),{ }^{31} \mathrm{P} \mathrm{NMR}\left(500 \mathrm{MHz}, \mathrm{CDCl}_{3}\right): \delta(\mathrm{ppm})$ $17.52(\mathrm{~s})$.

Secondly, the CP-b was synthesized via ring-opening reaction. All glassware was flam dried and protected by argon before using. Briefly, COP-b $(0.03 \mathrm{~mol}, 5.34 \mathrm{~g})$, 2(dimethylamino)ethyl acrylate, and BHT (100 mg) were added to $50 \mathrm{~mL}$ acetonitrile (dried via $\mathrm{Na}$ and distilled freshly before using). The reaction was conducted at $70{ }^{\circ} \mathrm{C}$ for $56 \mathrm{~h}$, 
and then the solution was precipitated three times via THF, after removed the THF, the CPb was obtained with yield $89.7 \% .{ }^{1} \mathrm{H}$ NMR $\left(500 \mathrm{MHz}, \mathrm{D}_{2} \mathrm{O}\right.$ ): 6.43 and 6.21 (d and $\mathrm{m}$, $\left.\mathrm{OCCH}=\mathrm{CH}_{2}\right), 6.01\left(\mathrm{~d},-\mathrm{OCC} \boldsymbol{H}=\mathrm{CH}_{2}\right), 5.83\left(\mathrm{~m}, \mathrm{P}-\mathrm{OCH}_{2}-\mathrm{CH}_{2}-\mathrm{CH}=\mathrm{CH}_{2}\right), 5.18\left(\mathrm{~m}, \mathrm{P}-\mathrm{OCH}_{2}-\right.$ $\left.\mathrm{CH}_{2}-\mathrm{CH}=\mathrm{CH}_{2}\right), 4.64$ (t, $\left.-\mathrm{CH}_{2} \mathrm{O}-\mathrm{CO}-\right), 4.29$ (t, - $\left.\mathrm{CH}_{2} \mathrm{OP}\right)$, 3.93-3.86 (m, $\left.-\mathrm{CH}_{2} \mathrm{~N}\left(\mathrm{CH}_{3}\right)_{2}-\mathrm{CH}_{2}-\right)$, $3.75\left(\mathrm{~d}, \mathrm{P}-\mathrm{OCH} \mathrm{H}_{2}-\mathrm{CH}_{2}-\right), 3.25\left(\mathrm{~s},-\mathrm{N}-\left(\mathrm{CH}_{3}\right)_{2}\right), 2.37\left(\mathrm{~m}, \mathrm{P}-\mathrm{OCH}_{2}-\mathrm{CH}_{2}-\mathrm{CH}=\mathrm{CH}_{2}\right) ;{ }^{11} \mathrm{P}$ NMR $\left(500 \mathrm{MHz}, \mathrm{D}_{2} \mathrm{O}\right): \delta(\mathrm{ppm})-0.24(\mathrm{~s})$.

Synthesis of CP-c: In brief, the COP-c was synthesized at first. All glassware was flam dried and protected by argon before using. 3-Butyn-1-ol $(0.1 \mathrm{~mol}, 7.00 \mathrm{~g})$ prepared via distilling $\mathrm{CaH}_{2}$ mixed solution, 2-chloro-2-oxo-1,3,2-dioxaphospholane $(0.1 \mathrm{~mol}, 14.21 \mathrm{~g})$, and THF (150 mL, dried via Na and distilled freshly before using) were added to $250 \mathrm{~mL}$ Schlenk flask under the argon protection. The solution was stirred and cooled to $-78^{\circ} \mathrm{C}$. Then, the triethylamine $\left(0.11 \mathrm{~mol}, 11.11 \mathrm{~g}\right.$, dried via $\mathrm{CaH}_{2}$ and distilled freshly before using) was added dropwise about $2 \mathrm{~h}$, and the solution was reacted at room temperature for another $4 \mathrm{~h}$. After that, the solution was cooled to $-40^{\circ} \mathrm{C}$ to filter off the white precipitate, the filtrate was directly distilled at Schlenk flask, where the whole process was conducted under argon atmosphere. Finally, the obtained liquid was purified via vacuum distillation, and the COPc was collected with yield $84.9 \% .{ }^{1} \mathrm{H}$ NMR $\left(500 \mathrm{MHz}, \mathrm{CDCl}_{3}\right): 4.47\left(\mathrm{~m},-\mathrm{OCH}_{2} \mathrm{CH}_{2} \mathrm{O}-\right), 4.26$ (m, $\left.-\mathrm{OCH}_{2} \mathrm{CH}_{2} \mathrm{C} \equiv \mathrm{CH}\right), 2.45\left(\mathrm{~m},-\mathrm{OCH}_{2} \mathrm{CH}_{2} \mathrm{C} \equiv \mathrm{CH}\right),{ }^{31} \mathrm{P} \mathrm{NMR}\left(500 \mathrm{MHz}, \mathrm{CDCl}_{3}\right): \delta(\mathrm{ppm})$ $17.35(\mathrm{~s})$. 
Secondly, the CP-c was synthesized via ring-opening reaction. All glassware was flam dried and protected by argon before using. Briefly, COP-c $(0.03 \mathrm{~mol}, 5.34 \mathrm{~g})$, 2(dimethylamino)ethyl acrylate, and $\mathrm{BHT}(100 \mathrm{mg}$ ) were added to $50 \mathrm{~mL}$ acetonitrile (dried via $\mathrm{Na}$ and distilled freshly before using). The reaction was conducted at $70{ }^{\circ} \mathrm{C}$ for $56 \mathrm{~h}$, and then the solution was precipitated three times via THF, after removed the THF, the CPc was obtained with yield $86.3 \% .{ }^{1} \mathrm{H}$ NMR $\left(500 \mathrm{MHz}, \mathrm{D}_{2} \mathrm{O}\right): 6.43$ and 6.24 (d and $\mathrm{m}$, $\left.\mathrm{OCCH}=\mathrm{CH}_{2}\right), 6.03\left(\mathrm{~d},-\mathrm{OCCH}=\mathrm{CH}_{2}\right), 4.65\left(\mathrm{t},-\mathrm{CH}_{2} \mathrm{O}-\mathrm{CO}-\right), 4.34\left(\mathrm{t},-\mathrm{CH}_{2} \mathrm{OP}\right), 3.95-3.86(\mathrm{~m}$, $\left.-\mathrm{CH}_{2} \mathrm{~N}\left(\mathrm{CH}_{3}\right)_{2}-\mathrm{CH}_{2-}\right), 3.77\left(\mathrm{~d}, \mathrm{P}-\mathrm{OCH}_{2}-\mathrm{CH}_{2}-\right), 3.26\left(\mathrm{~s},-\mathrm{N}-\left(\mathrm{CH}_{3}\right)_{2}\right), 2.65$ (s, P-OCH${ }_{2}-\mathrm{CH}_{2-}$ $\mathrm{C} \equiv \mathrm{CH}), 2.55\left(\mathrm{~m}, \mathrm{P}-\mathrm{OCH}_{2}-\mathrm{CH}_{2}-\mathrm{C} \equiv \mathrm{CH}\right) ;{ }^{31} \mathrm{P} \mathrm{NMR}\left(500 \mathrm{MHz}, \mathrm{D}_{2} \mathrm{O}\right): \delta$ (ppm) -0.65 (s).

\section{The conjugation of "tails" and "heads" of lipids}

\section{Synthesis of DPCP lipids}

Synthesis of DPCP-a: The "tail" and "head" of. Lipids were conjugated via Michael addition reaction. Briefly, DPCA (1 mmol, 0.57g), CP-a (3mmol, 0.97g) were added into $20 \mathrm{~mL}$ mixed solution (DMSO : acetonitrile : dichloromethane) and stirred. Then the catalyst of triethylamine was added, the reaction was conducted at $65^{\circ} \mathrm{C}$ for $48 \mathrm{~h}$. Finally, the solution was added into $100 \mathrm{~mL}$ water containing $5.0 \mathrm{wt} \% \mathrm{Na}_{2} \mathrm{CO}_{3}$. The precipitation was filtered off, and the filtrate was directly dialyzed against UP water for $48 \mathrm{~h}$ with MWCO 3500 membrane to remove $\mathrm{Na}_{2} \mathrm{CO}_{3}$, the dialysis water was replaced of the fresh every $8 \mathrm{~h}$. After freezedrying, the solid was dissolved in cold PBS ( $\mathrm{pH} 9.0)$, and store in $4{ }^{\circ} \mathrm{C}$ overnight. After that, 
the precipitation was filtered off, and the filtrate was dialyzed against UP water for $48 \mathrm{~h}$ with MWCO 3500 membrane to remove salt again. After freeze-drying, the DPCP-a was collected with yield 10.8\%. ${ }^{1} \mathrm{H}$ NMR $\left(500 \mathrm{MHz}, \mathrm{CDCl}_{3}\right): 4.68\left(\mathrm{t},-\mathrm{COOCH}_{2} \mathrm{CH}_{2}-\mathrm{N}^{+}\right), 4.56(\mathrm{~m}$, $\left.-\mathrm{COOCH}_{2} \mathrm{CH}(\mathrm{OOC}-) \mathrm{CH}_{2}-\mathrm{NH}-\right), 4.27$ (m, - $\left.\mathrm{COOCH}_{2} \mathrm{CH}(\mathrm{OOC}-) \mathrm{CH}_{2}-\mathrm{NH}-\right)$, 3.83-4.09 (m, -

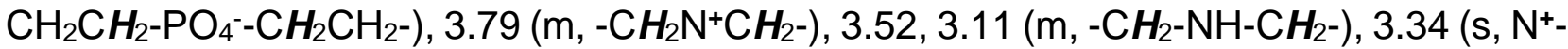
$\left.\left(\mathrm{CH}_{3}\right)_{2}\right)$, 2.38 (m, - $\mathrm{NHCH}_{2} \mathrm{CH}_{2} \mathrm{COO}-,-\mathrm{PO}-\mathrm{CH}_{2} \mathrm{CH}_{2} \mathrm{CH}_{2} \mathrm{CH}_{3}$ ), 2.26 (t, - $\left.\mathrm{CH}_{2} \mathrm{CH}_{2} \mathrm{COO}-\right)$, 1.581.69 (m, - $\left.\mathrm{CH}_{2} \mathrm{CH}_{2} \mathrm{COO}\right)$, 1.27 (m, $\left.\mathrm{CH}_{3}\left(\mathrm{CH}_{2}\right)_{12} \mathrm{CH}_{2}-,-\mathrm{PO}-\mathrm{CH}_{2} \mathrm{CH}_{2} \mathrm{CH}_{2} \mathrm{CH}_{3}\right), 0.91$ (t, $\left.\mathrm{CH}_{3}\left(\mathrm{CH}_{2}\right){ }_{12} \mathrm{CH}_{2-},-\mathrm{PO}-\mathrm{CH}_{2} \mathrm{CH}_{2} \mathrm{CH}_{2} \mathrm{CH}_{3}\right) ;{ }^{31} \mathrm{P} \mathrm{NMR}\left(500 \mathrm{MHz}, \mathrm{CDCl}_{3}\right): \delta$ (ppm) 0.46 (s).. HRESI-mass spectrum calculated for C48H95N2O10P 891.27, found $891.67(\mathrm{M}+\mathrm{H}), 913.66$ $(\mathrm{M}+\mathrm{Na})$.

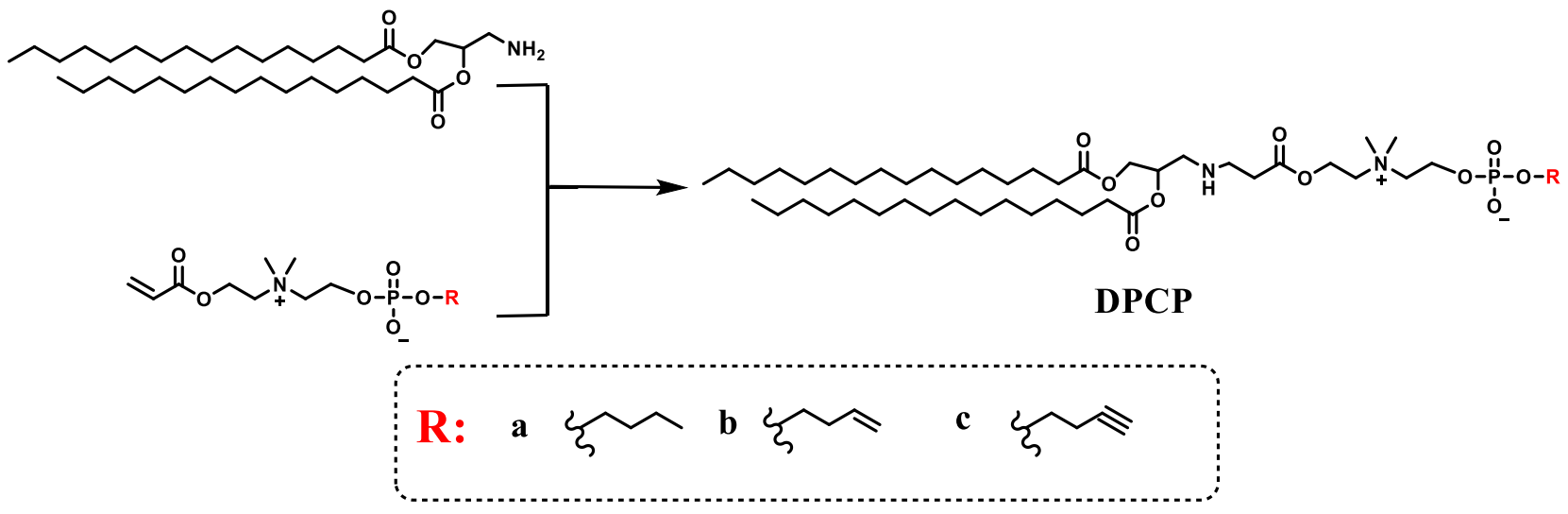

\section{Scheme 5: Synthesis of DPCP lipids}

Synthesis of DPCP-b: The above-mentioned method was used. Briefly, DPCA $(1 \mathrm{mmol}$, 0.57g), CP-b (3mmol, 0.96g) were added into $20 \mathrm{~mL}$ mixed solution (DMSO : acetonitrile : dichloromethane) and stirred. Then the catalyst of triethylamine was added, the reaction 
was conducted at $65{ }^{\circ} \mathrm{C}$ for $48 \mathrm{~h}$. Finally, the solution was added into $100 \mathrm{~mL}$ water containing 5.0 wt $\% \mathrm{Na}_{2} \mathrm{CO}_{3}$. The precipitation was filtered off, and the filtrate was directly dialyzed against UP water for $48 \mathrm{~h}$ with MWCO 3500 membrane to remove $\mathrm{Na}_{2} \mathrm{CO}_{3}$, the dialysis water was replaced of the fresh every $8 \mathrm{~h}$. After freeze-drying, the solid was dissolved in cold PBS ( $\mathrm{pH}$ 9.0), and store in $4{ }^{\circ} \mathrm{C}$ overnight. After that, the precipitation was filtered off, and the filtrate was dialyzed against UP water for $48 \mathrm{~h}$ with MWCO 3500 membrane to remove salt again. After freeze-drying, the DPCP-b was collected with yield 11.6\%. ${ }^{1} \mathrm{H}$ NMR $\left(500 \mathrm{MHz}, \mathrm{CDCl}_{3}\right): 5.79\left(\mathrm{~m},-\mathrm{POCH}_{2} \mathrm{CH}_{2} \mathrm{CH}=\mathrm{CH}_{2}\right), 5.03-5.17(\mathrm{~m},-$ $\left.\mathrm{POCH}_{2} \mathrm{CH}_{2} \mathrm{CH}=\mathrm{CH}_{2}\right)$, m 4.68 (t, $\left.-\mathrm{COOCH}_{2} \mathrm{CH}_{2}-\mathrm{N}^{+}\right), 4.59$ (m, $-\mathrm{COOCH}_{2} \mathrm{CH}(\mathrm{OOC}-) \mathrm{CH}_{2}{ }^{-}$ $\mathrm{NH}-), 4.29\left(\mathrm{~m},-\mathrm{COOCH}_{2} \mathrm{CH}(\mathrm{OOC}-) \mathrm{CH}_{2}-\mathrm{NH}-\right), 4.03-4.17\left(\mathrm{~m},-\mathrm{CH}_{2} \mathrm{CH}_{2}-\mathrm{PO}_{4}^{-}-\mathrm{CH}_{2} \mathrm{CH}_{2}-\right)$, 3.76-3.91 (m, $\left.-\mathrm{CH}_{2} \mathrm{~N}^{+} \mathrm{CH}_{2-}\right), 3.53,3.09\left(\mathrm{~m},-\mathrm{CH}_{2}-\mathrm{NH}_{-} \mathrm{CH}_{2-}\right), 3.34\left(\mathrm{~s}, \mathrm{~N}^{+}-\left(\mathrm{CH}_{3}\right)_{2}\right), 2.42(\mathrm{~m},-$ $\left.\mathrm{NHCH}_{2} \mathrm{CH}_{2} \mathrm{COO}-, \quad-\mathrm{PO}-\mathrm{CH}_{2} \mathrm{CH}_{2} \mathrm{CH}=\mathrm{CH}_{2}\right), \quad 2.26 \quad\left(\mathrm{t}, \quad-\mathrm{CH}_{2} \mathrm{CH}_{2} \mathrm{COO}-\right), \quad 1.64 \quad(\mathrm{~m}, \quad-$ $\left.\mathrm{CH}_{2} \mathrm{CH}_{2} \mathrm{COO}-\right), 1.26\left(\mathrm{~m}, \mathrm{CH}_{3}\left(\mathrm{CH}_{2}\right){ }_{12} \mathrm{CH}_{2}-\right), 0.89$ (t, $\left.\mathrm{CH}_{3}\left(\mathrm{CH}_{2}\right){ }_{10} \mathrm{CH}_{2^{-}}\right) ;{ }^{31} \mathrm{P} \mathrm{NMR}(500 \mathrm{MHz}$, $\left.\mathrm{CDCl}_{3}\right): \delta(\mathrm{ppm})-1.22(\mathrm{~s})$. HR-ESI-mass spectrum calculated for C48H93N2O10P 889.25, found $889.66(\mathrm{M}+\mathrm{H}), 911.50(\mathrm{M}+\mathrm{Na})$.

Synthesis of DPCP-c: The above-mentioned method was used. Briefly, DPCA (1 $\mathrm{mmol}$, $0.57 \mathrm{~g})$, CP-c (3mmol, 0.95g) were added into $20 \mathrm{~mL}$ mixed solution (DMSO : acetonitrile : dichloromethane) and stirred. Then the catalyst of triethylamine was added, the reaction was conducted at $65{ }^{\circ} \mathrm{C}$ for $48 \mathrm{~h}$. Finally, the solution was added into $100 \mathrm{~mL}$ water containing $5.0 \mathrm{wt} \% \mathrm{Na}_{2} \mathrm{CO}_{3}$. The precipitation was filtered off, and the filtrate was directly 
dialyzed against UP water for $48 \mathrm{~h}$ with MWCO 3500 membrane to remove $\mathrm{Na}_{2} \mathrm{CO}_{3}$, the dialysis water was replaced of the fresh every $8 \mathrm{~h}$. After freeze-drying, the solid was dissolved in cold PBS ( $\mathrm{pH}$ 9.0), and store in $4{ }^{\circ} \mathrm{C}$ overnight. After that, the precipitation was filtered off, and the filtrate was dialyzed against UP water for $48 \mathrm{~h}$ with MWCO 3500 membrane to remove salt again. After freeze-drying, the DPCP-c was collected with yield 9.9\%. ${ }^{1} \mathrm{H} \quad \mathrm{NMR} \quad\left(500 \mathrm{MHz}, \quad \mathrm{CDCl}_{3}\right): 4.65 \quad\left(\mathrm{t}, \quad-\mathrm{COOCH}_{2} \mathrm{CH}_{2}-\mathrm{N}^{+}\right), \quad 4.38 \quad(\mathrm{~m}, \quad-$ $\left.\mathrm{COOCH}_{2} \mathrm{CH}(\mathrm{OOC}-) \mathrm{CH}_{2}-\mathrm{NH}-\right), 4.21$ (m, - $\left.\mathrm{COOCH}_{2} \mathrm{CH}(\mathrm{OOC}-) \mathrm{CH}_{2}-\mathrm{NH}-\right)$, 3.866-4.13 (m, $\left.\mathrm{CH}_{2} \mathrm{CH}_{2}-\mathrm{PO}_{4}^{-}-\mathrm{CH}_{2} \mathrm{CH}_{2}-\right), 3.74\left(\mathrm{~m},-\mathrm{CH}_{2} \mathrm{~N}^{+} \mathrm{CH}_{2}{ }^{-}\right), 3.52,3.11\left(\mathrm{~m},-\mathrm{CH}_{2}-\mathrm{NH}^{-} \mathrm{CH}_{2}^{-}\right), 3.35\left(\mathrm{~s}, \mathrm{~N}^{+}-\right.$ $\left.\left(\mathrm{CH}_{3}\right)_{2}\right), 2.54$ (m, - $\left.\mathrm{NHCH}_{2} \mathrm{CH}_{2} \mathrm{COO}-,-\mathrm{PO}-\mathrm{CH}_{2} \mathrm{CH}_{2} \mathrm{C} \equiv \mathrm{CH}\right), 2.32$ (t, $\left.-\mathrm{CH}_{2} \mathrm{CH}_{2} \mathrm{COO}-\right)$, 2.07 (s, $\left.-\mathrm{PO}-\mathrm{CH}_{2} \mathrm{CH}_{2} \mathrm{C} \equiv \mathrm{CH}\right), \quad 1.64\left(\mathrm{~m},-\mathrm{CH}_{2} \mathrm{CH}_{2} \mathrm{COO}-\right), 1.31\left(\mathrm{~m}, \mathrm{CH}_{3}\left(\mathrm{CH}_{2}\right){ }_{12} \mathrm{CH}_{2}-\right), 0.88$ (t, $\mathrm{CH}_{3}\left(\mathrm{CH}_{2}\right){ }_{10} \mathrm{CH}_{2}$ ); ${ }^{31} \mathrm{P} \mathrm{NMR}\left(500 \mathrm{MHz}, \mathrm{CDCl}_{3}\right): \delta(\mathrm{ppm}) 0.54$ (s). HR-ESI-mass spectrum calculated for C48H93N2O10P 889.25, found 887.64 $(\mathrm{M}+\mathrm{H}), 909.62(\mathrm{M}+\mathrm{Na})$.

\section{Synthesis of DMCP lipids}

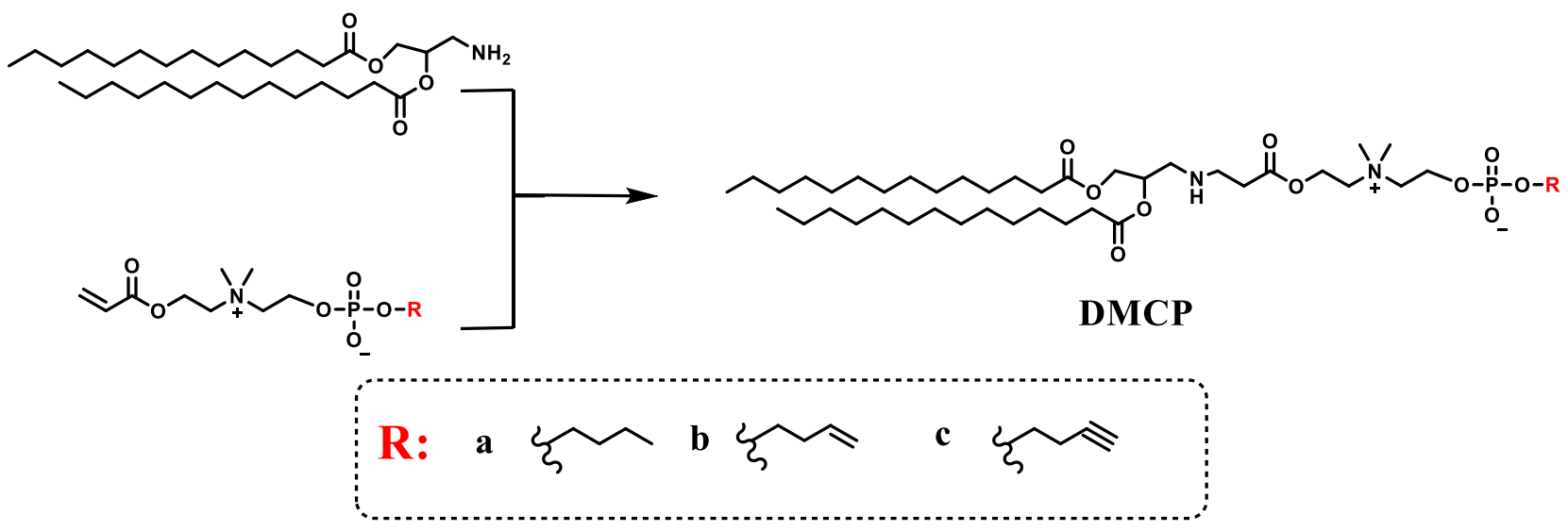


Synthesis of DMCP-a: Briefly, DMCA (1mmol, 0.51g), CP-a (3mmol, 0.97g) were added into $20 \mathrm{~mL}$ mixed solution (DMSO : acetonitrile : dichloromethane) and stirred. Then the catalyst of triethylamine was added, the reaction was conducted at $65^{\circ} \mathrm{C}$ for $48 \mathrm{~h}$. Finally, the solution was added into $100 \mathrm{~mL}$ water containing $5.0 \mathrm{wt} \% \mathrm{Na}_{2} \mathrm{CO}_{3}$. The precipitation was filtered off, and the filtrate was directly dialyzed against UP water for $48 \mathrm{~h}$ with MWCO 3500 membrane to remove $\mathrm{Na}_{2} \mathrm{CO}_{3}$, the dialysis water was replaced of the fresh every $8 \mathrm{~h}$. After freeze-drying, the solid was dissolved in cold PBS ( $\mathrm{pH} 9.0$ ), and store in $4{ }^{\circ} \mathrm{C}$ overnight. After that, the precipitation was filtered off, and the filtrate was dialyzed against UP water for $48 \mathrm{~h}$ with MWCO 3500 membrane to remove salt again. After freeze-drying, the DMCPa was collected with yield $21.4 \% .{ }^{1} \mathrm{H}$ NMR $\left(500 \mathrm{MHz}, \mathrm{CDCl}_{3}\right): 4.87\left(\mathrm{t},-\mathrm{COOCH}_{2} \mathrm{CH}_{2}-\mathrm{N}^{+}\right)$, $4.70\left(\mathrm{~m},-\mathrm{COOCH}_{2} \mathrm{CH}(\mathrm{OOC}-) \mathrm{CH}_{2}-\mathrm{NH}-\right)$, 4.29 (m, $\left.-\mathrm{COOCH}_{2} \mathrm{CH}(\mathrm{OOC}-) \mathrm{CH}_{2}-\mathrm{NH}-\right)$, 4.04-4.19 (m, $\left.-\mathrm{CH}_{2} \mathrm{CH}_{2}-\mathrm{PO}_{4}{ }^{-}-\mathrm{CH}_{2} \mathrm{CH}_{2}-\right)$, 3.64-3.78 (m, $-\mathrm{CH}_{2} \mathrm{~N}^{+} \mathrm{CH}_{2-}$ ), 3.51 (m, $-\mathrm{CH}_{2}-\mathrm{NH}-\mathrm{CH}_{2-}$ ), 3.30 (s, $\left.\mathrm{N}^{+}-\left(\mathrm{CH}_{3}\right)_{2}\right), 2.34$ (m, - $\mathrm{NHCH}_{2} \mathrm{CH}_{2} \mathrm{COO}-,-\mathrm{PO}-\mathrm{CH}_{2} \mathrm{CH}_{2} \mathrm{CH}_{2} \mathrm{CH}_{3}$ ), 2.21 (t, - $\left.\mathrm{CH}_{2} \mathrm{CH}_{2} \mathrm{COO}-\right)$, 1.61 (m, - $\left.\mathrm{CH}_{2} \mathrm{CH}_{2} \mathrm{COO}-\right), 1.26\left(\mathrm{~m}, \mathrm{CH}_{3}\left(\mathrm{CH}_{2}\right){ }_{10} \mathrm{CH}_{2^{-}},-\mathrm{PO}-\mathrm{CH}_{2} \mathrm{CH}_{2} \mathrm{CH}_{2} \mathrm{CH}_{3}\right), 0.88$ (t, $\left.\mathrm{CH}_{3}\left(\mathrm{CH}_{2}\right){ }_{10} \mathrm{CH}_{2}-,-\mathrm{PO}-\mathrm{CH}_{2} \mathrm{CH}_{2} \mathrm{CH}_{2} \mathrm{CH}_{3}\right) ;{ }^{31} \mathrm{P} \mathrm{NMR}\left(500 \mathrm{MHz}, \mathrm{CDCl}_{3}\right): \delta(\mathrm{ppm})-0.17$ (s). HRESI-mass spectrum calculated for C44H87N2O10P 835.16, found 835.61 $(\mathrm{M}+\mathrm{H}), 857.59$ $(\mathrm{M}+\mathrm{Na})$.

Synthesis of DMCP-b: Briefly, DMCA (1mmol, 0.51g), CP-b (3mmol, 0.96g) were added into $20 \mathrm{~mL}$ mixed solution (DMSO : acetonitrile : dichloromethane) and stirred. Then the catalyst of triethylamine was added, the reaction was conducted at $65^{\circ} \mathrm{C}$ for $48 \mathrm{~h}$. Finally, the 
solution was added into $100 \mathrm{~mL}$ water containing $5.0 \mathrm{wt} \% \mathrm{Na}_{2} \mathrm{CO}_{3}$. The precipitation was filtered off, and the filtrate was directly dialyzed against UP water for $48 \mathrm{~h}$ with MWCO 3500 membrane to remove $\mathrm{Na}_{2} \mathrm{CO}_{3}$, the dialysis water was replaced of the fresh every $8 \mathrm{~h}$. After freeze-drying, the solid was dissolved in cold PBS ( $\mathrm{pH} 9.0)$, and store in $4{ }^{\circ} \mathrm{C}$ overnight. After that, the precipitation was filtered off, and the filtrate was dialyzed against UP water for $48 \mathrm{~h}$ with MWCO 3500 membrane to remove salt again. After freeze-drying, the DMCPb was collected with yield 20.3\%. ${ }^{1} \mathrm{H}$ NMR $\left(500 \mathrm{MHz}, \mathrm{CDCl}_{3}\right): 5.77\left(\mathrm{~m},-\mathrm{POCH}_{2} \mathrm{CH}_{2} \mathrm{CH}=\mathrm{CH}_{2}\right)$, 5.01-5.07 (m, $\left.\quad-\mathrm{POCH}_{2} \mathrm{CH}_{2} \mathrm{CH}=\mathrm{CH}_{2}\right), \quad m \quad 4.64 \quad\left(\mathrm{t}, \quad-\mathrm{COOCH}_{2} \mathrm{CH}_{2}-\mathrm{N}^{+}\right), 4.55 \quad(\mathrm{~m}, \quad-$ $\left.\mathrm{COOCH}_{2} \mathrm{CH}(\mathrm{OOC}-) \mathrm{CH}_{2}-\mathrm{NH}-\right), 4.27$ (m, $\left.-\mathrm{COOCH}_{2} \mathrm{CH}(\mathrm{OOC}-) \mathrm{CH}_{2}-\mathrm{NH}-\right), 4.08-4.14$ (m, $\left.\mathrm{CH}_{2} \mathrm{CH}_{2}-\mathrm{PO}_{4}^{-}-\mathrm{CH}_{2} \mathrm{CH}_{2}-\right)$, 3.86-3.93 (m, $\left.-\mathrm{CH}_{2} \mathrm{~N}^{+} \mathrm{CH}_{2}-\right)$, 3.49, 3.23 (m, - $\left.\mathrm{CH}_{2}-\mathrm{NH}-\mathrm{CH}_{2-}\right)$, 3.36 (s, $\left.\mathrm{N}^{+}-\left(\mathrm{CH}_{3}\right)_{2}\right), 2.35\left(\mathrm{~m},-\mathrm{NHCH}_{2} \mathrm{CH}_{2} \mathrm{COO}-,-\mathrm{PO}-\mathrm{CH}_{2} \mathrm{CH}_{2} \mathrm{CH}=\mathrm{CH}_{2}\right), 2.21$ (t, $\left.-\mathrm{CH}_{2} \mathrm{CH}_{2} \mathrm{COO}-\right)$, 1.62 (m, $\left.-\mathrm{CH}_{2} \mathrm{CH}_{2} \mathrm{COO}-\right), 1.25$ (m, $\left.\mathrm{CH}_{3}\left(\mathrm{CH}_{2}\right){ }_{10} \mathrm{CH}_{2}-\right), 0.88$ (t, $\left.\mathrm{CH}_{3}\left(\mathrm{CH}_{2}\right){ }_{10} \mathrm{CH}_{2}-\right) ;{ }^{31} \mathrm{P} \mathrm{NMR}$ $\left(500 \mathrm{MHz}, \quad \mathrm{CDCl}_{3}\right): \quad \delta \quad(\mathrm{ppm}) \quad-0.93 \quad$ (s). HR-ESI-mass spectrum calculated for C44H85N2O10P 832.59, found 835.71 $(\mathrm{M}+\mathrm{H}), 853.56(\mathrm{M}+\mathrm{Na})$.

Synthesis of DMCP-c: Briefly, DMCA (1mmol, 0.51g), CP-c (3mmol, 0.95g) were added into $20 \mathrm{~mL}$ mixed solution (DMSO : acetonitrile : dichloromethane) and stirred. Then the catalyst of triethylamine was added, the reaction was conducted at $65^{\circ} \mathrm{C}$ for $48 \mathrm{~h}$. Finally, the solution was added into $100 \mathrm{~mL}$ water containing $5.0 \mathrm{wt} \% \mathrm{Na}_{2} \mathrm{CO}_{3}$. The precipitation was filtered off, and the filtrate was directly dialyzed against UP water for $48 \mathrm{~h}$ with MWCO 3500 membrane to remove $\mathrm{Na}_{2} \mathrm{CO}_{3}$, the dialysis water was replaced of the fresh every $8 \mathrm{~h}$. After 
freeze-drying, the solid was dissolved in cold PBS (pH 9.0), and store in $4{ }^{\circ} \mathrm{C}$ overnight. After that, the precipitation was filtered off, and the filtrate was dialyzed against UP water for $48 \mathrm{~h}$ with MWCO 3500 membrane to remove salt again. After freeze-drying, the DMCPc was collected with yield $23.6 \% .{ }^{1} \mathrm{H}$ NMR $\left(500 \mathrm{MHz}, \mathrm{CDCl}_{3}\right): 4.70\left(\mathrm{t},-\mathrm{COOCH}_{2} \mathrm{CH}_{2}-\mathrm{N}^{+}\right)$, 4.68 (m, - $\left.\mathrm{COOCH}_{2} \mathrm{CH}(\mathrm{OOC}-) \mathrm{CH}_{2}-\mathrm{NH}-\right)$, 4.35 (m, - $\left.\mathrm{COOCH}_{2} \mathrm{CH}(\mathrm{OOC}-) \mathrm{CH}_{2}-\mathrm{NH}-\right)$, 4.06-4.17 (m, $\left.-\mathrm{CH}_{2} \mathrm{CH}_{2}-\mathrm{PO}_{4}{ }^{-}-\mathrm{CH}_{2} \mathrm{CH}_{2}-\right), 3.94\left(\mathrm{~m},-\mathrm{CH}_{2} \mathrm{~N}^{+} \mathrm{CH}_{2}{ }^{-}\right), 3.52,3.23\left(\mathrm{~m},-\mathrm{CH}_{2}-\mathrm{NH}^{-} \mathrm{CH}_{2}{ }^{-}\right), 3.33$ (s, $\left.\mathrm{N}^{+}-\left(\mathrm{CH}_{3}\right)_{2}\right), 2.52\left(\mathrm{~m},-\mathrm{NHCH}_{2} \mathrm{CH}_{2} \mathrm{COO}-,-\mathrm{PO}-\mathrm{CH}_{2} \mathrm{CH}_{2} \mathrm{C} \equiv \mathrm{CH}\right), 2.23$ (t, - $\left.\mathrm{CH}_{2} \mathrm{CH}_{2} \mathrm{COO}-\right)$, 2.20 (s, - $\left.\mathrm{PO}-\mathrm{CH}_{2} \mathrm{CH}_{2} \mathrm{C} \equiv \mathrm{CH}\right), 1.62\left(\mathrm{~m},-\mathrm{CH}_{2} \mathrm{CH}_{2} \mathrm{COO}-\right), 1.23\left(\mathrm{~m}, \mathrm{CH}_{3}\left(\mathrm{CH}_{2}\right){ }_{10} \mathrm{CH}_{2}-\right), 0.87$ (t, $\left.\mathrm{CH}_{3}\left(\mathrm{CH}_{2}\right){ }_{10} \mathrm{CH}_{2}-\right) ;{ }^{31} \mathrm{P} \mathrm{NMR}\left(500 \mathrm{MHz}, \mathrm{CDCl}_{3}\right): \delta$ (ppm) -1.04 (s). HR-ESI-mass spectrum calculated for C44H83N2O10P, 831.13, found $831.58(\mathrm{M}+\mathrm{H}), 853.57(\mathrm{M}+\mathrm{Na})$.

\section{Synthesis of DDCP lipids}

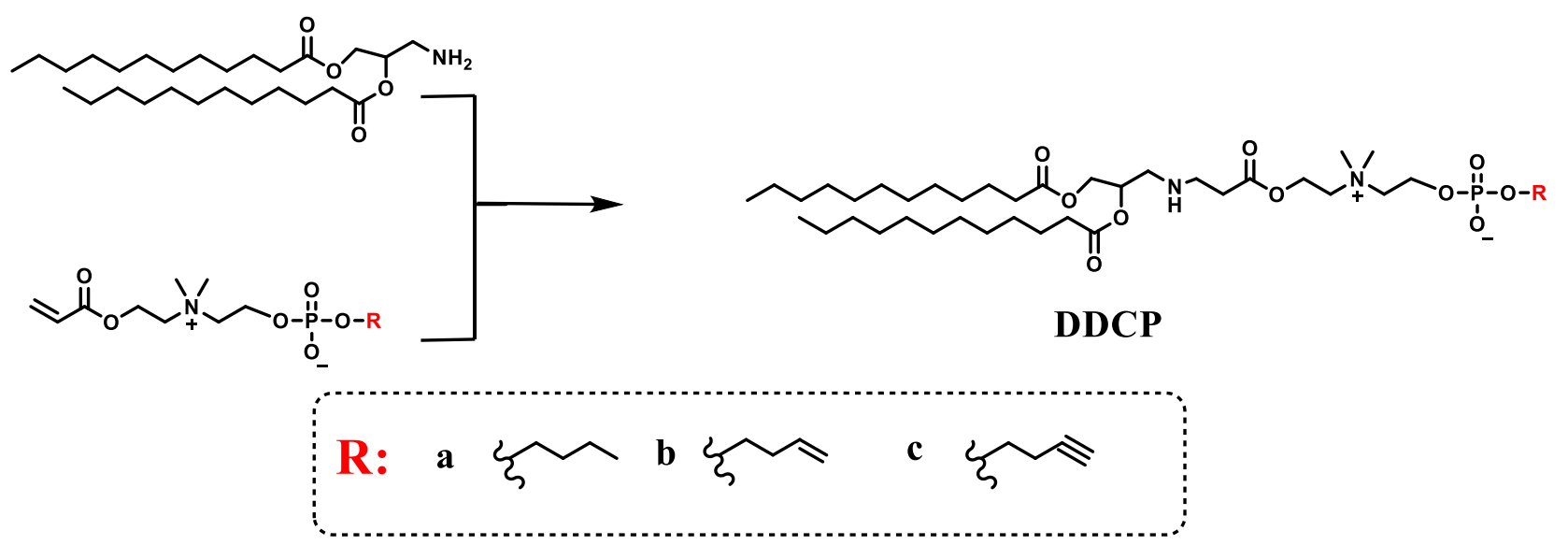


Synthesis of DDCP-a: Briefly, DDCA (1 $\mathrm{mmol}, 0.45 \mathrm{~g})$, CP-a $(3 \mathrm{mmol}, 0.97 \mathrm{~g})$ were added into $20 \mathrm{~mL}$ mixed solution (DMSO : acetonitrile : dichloromethane) and stirred. Then the catalyst of triethylamine was added, the reaction was conducted at $65^{\circ} \mathrm{C}$ for $48 \mathrm{~h}$. Finally, the solution was added into $100 \mathrm{~mL}$ water containing $5.0 \mathrm{wt} \% \mathrm{Na}_{2} \mathrm{CO}_{3}$. The precipitation was filtered off, and the filtrate was directly dialyzed against UP water for $48 \mathrm{~h}$ with MWCO 3500 membrane to remove $\mathrm{Na}_{2} \mathrm{CO}_{3}$, the dialysis water was replaced of the fresh every $8 \mathrm{~h}$. After freeze-drying, the solid was dissolved in cold PBS ( $\mathrm{pH} 9.0$ ), and store in $4{ }^{\circ} \mathrm{C}$ overnight. After that, the precipitation was filtered off, and the filtrate was dialyzed against UP water for $48 \mathrm{~h}$ with MWCO 3500 membrane to remove salt again. After freeze-drying, the DDCPa was collected with yield $31.4 \% .{ }^{1} \mathrm{H} \mathrm{NMR}\left(500 \mathrm{MHz}, \mathrm{CDCl}_{3}\right): 4.66\left(\mathrm{t},-\mathrm{COOCH}_{2} \mathrm{CH}_{2}-\mathrm{N}^{+}\right)$, $4.55\left(\mathrm{~m},-\mathrm{COOCH}_{2} \mathrm{CH}(\mathrm{OOC}-) \mathrm{CH}_{2}-\mathrm{NH}-\right), 4.28\left(\mathrm{~m},-\mathrm{COOCH}_{2} \mathrm{CH}(\mathrm{OOC}-) \mathrm{CH}_{2}-\mathrm{NH}-\right)$, 3.87-3.98 (m, $-\mathrm{CH}_{2} \mathrm{CH}_{2}-\mathrm{PO}_{4}{ }^{-}-\mathrm{CH}_{2} \mathrm{CH}_{2-}$ ), $3.80\left(\mathrm{~m},-\mathrm{CH}_{2} \mathrm{~N}^{+} \mathrm{CH}_{2}{ }^{-}\right)$, 3.52, 3.10 (m, - $\mathrm{CH}_{2}-\mathrm{NH}-\mathrm{CH}_{2-}$ ), 3.35 (s, $\left.\mathrm{N}^{+}-\left(\mathrm{CH}_{3}\right)_{2}\right), 2.30$ (m, - $\mathrm{NHCH}_{2} \mathrm{CH}_{2} \mathrm{COO}-,-\mathrm{PO}-\mathrm{CH}_{2} \mathrm{CH}_{2} \mathrm{CH}_{2} \mathrm{CH}_{3}$ ), 2.26 (t, - $\mathrm{CH}_{2} \mathrm{CH}_{2} \mathrm{COO}$-), 1.66 (m, - $\left.-\mathrm{CH}_{2} \mathrm{CH}_{2} \mathrm{COO}\right), 1.25$ (m, $\left.\mathrm{CH}_{3}\left(\mathrm{CH}_{2}\right)_{8} \mathrm{CH}_{2^{-}},-\mathrm{PO}^{-} \mathrm{CH}_{2} \mathrm{CH}_{2} \mathrm{CH}_{2} \mathrm{CH}_{3}\right), 0.88$ (t, $\left.\mathrm{CH}_{3}\left(\mathrm{CH}_{2}\right)_{8} \mathrm{CH}_{2-},-\mathrm{PO}-\mathrm{CH}_{2} \mathrm{CH}_{2} \mathrm{CH}_{2} \mathrm{CH}_{3}\right) ;{ }^{31} \mathrm{P} \mathrm{NMR}\left(500 \mathrm{MHz}, \mathrm{CDCl}_{3}\right): \delta$ (ppm) -0.64 (s). HRESI-mass spectrum calculated for $\mathrm{C} 40 \mathrm{H} 79 \mathrm{~N} 2 \mathrm{O} 10 \mathrm{P}$ 779.05, found $779.4(\mathrm{M}+\mathrm{H}), 801.7$ $(\mathrm{M}+\mathrm{Na})$.

Synthesis of DDCP-b: Briefly, DDCA (1 mmol, 0.45g), CP-b (3mmol, 0.96g) were added into $20 \mathrm{~mL}$ mixed solution (DMSO : acetonitrile : dichloromethane) and stirred. Then the catalyst of triethylamine was added, the reaction was conducted at $65^{\circ} \mathrm{C}$ for $48 \mathrm{~h}$. Finally, the 
solution was added into $100 \mathrm{~mL}$ water containing $5.0 \mathrm{wt} \% \mathrm{Na}_{2} \mathrm{CO}_{3}$. The precipitation was filtered off, and the filtrate was directly dialyzed against UP water for $48 \mathrm{~h}$ with MWCO 3500 membrane to remove $\mathrm{Na}_{2} \mathrm{CO}_{3}$, the dialysis water was replaced of the fresh every $8 \mathrm{~h}$. After freeze-drying, the solid was dissolved in cold PBS ( $\mathrm{pH} 9.0)$, and store in $4{ }^{\circ} \mathrm{C}$ overnight. After that, the precipitation was filtered off, and the filtrate was dialyzed against UP water for $48 \mathrm{~h}$ with MWCO 3500 membrane to remove salt again. After freeze-drying, the DDCPb was collected with yield 32.7\%. ${ }^{1} \mathrm{H}$ NMR $\left(500 \mathrm{MHz}, \mathrm{CDCl}_{3}\right): 5.80\left(\mathrm{~m},-\mathrm{POCH}_{2} \mathrm{CH}_{2} \mathrm{CH}=\mathrm{CH}_{2}\right)$, 5.01-5.11 (m, $\left.\quad-\mathrm{POCH}_{2} \mathrm{CH}_{2} \mathrm{CH}=\mathrm{CH}_{2}\right), \quad m \quad 4.66 \quad\left(\mathrm{t}, \quad-\mathrm{COOCH}_{2} \mathrm{CH}_{2}-\mathrm{N}^{+}\right), 4.55 \quad(\mathrm{~m}, \quad-$ $\left.\mathrm{COOCH}_{2} \mathrm{CH}(\mathrm{OOC}-) \mathrm{CH}_{2}-\mathrm{NH}-\right), 4.30$ (m, $\left.-\mathrm{COOCH}_{2} \mathrm{CH}(\mathrm{OOC}-) \mathrm{CH}_{2}-\mathrm{NH}-\right)$, 3.93-4.07 (m, $\left.\mathrm{CH}_{2} \mathrm{CH}_{2}-\mathrm{PO}_{4}^{-}{ }^{-} \mathrm{CH}_{2} \mathrm{CH}_{2}-\right)$, $3.85\left(\mathrm{~m},-\mathrm{CH}_{2} \mathrm{~N}^{+} \mathrm{CH}_{2^{-}}\right)$, 3.52, 3.09 (m, $\left.-\mathrm{CH}_{2}-\mathrm{NH}-\mathrm{CH}_{2^{-}}\right), 3.34$ (s, $\left.\mathrm{N}^{+}-\left(\mathrm{CH}_{3}\right)_{2}\right), 2.35$ (m, - $\left.\mathrm{NHCH}_{2} \mathrm{CH}_{2} \mathrm{COO}-,-\mathrm{PO}_{-} \mathrm{CH}_{2} \mathrm{CH}_{2} \mathrm{CH}=\mathrm{CH}_{2}\right), 2.26$ (t, $\left.-\mathrm{CH}_{2} \mathrm{CH}_{2} \mathrm{COO}-\right)$, $1.59\left(\mathrm{~m},-\mathrm{CH}_{2} \mathrm{CH}_{2} \mathrm{COO}-\right), 1.25\left(\mathrm{~m}, \mathrm{CH}_{3}\left(\mathrm{CH}_{2}\right)_{8} \mathrm{CH}_{2}-\right), 0.88\left(\mathrm{t}, \mathrm{CH}_{3}\left(\mathrm{CH}_{2}\right){ }_{10} \mathrm{CH}_{2-}\right) ;{ }^{31} \mathrm{P} \mathrm{NMR}$ $\left(500 \mathrm{MHz}, \quad \mathrm{CDCl}_{3}\right): \quad \delta \quad(\mathrm{ppm}) \quad-0.76 \quad$ (s). HR-ESI-mass spectrum calculated for C40H77N2O10P 777.03, found 777.53(M+H), $799.52(\mathrm{M}+\mathrm{Na})$.

Synthesis of DDCP-c: Briefly, DDCA (1mmol, 0.45g), CP-c (3mmol, 0.95g) were added into $20 \mathrm{~mL}$ mixed solution (DMSO : acetonitrile : dichloromethane) and stirred. Then the catalyst of triethylamine was added, the reaction was conducted at $65^{\circ} \mathrm{C}$ for $48 \mathrm{~h}$. Finally, the solution was added into $100 \mathrm{~mL}$ water containing $5.0 \mathrm{wt} \% \mathrm{Na}_{2} \mathrm{CO}_{3}$. The precipitation was filtered off, and the filtrate was directly dialyzed against UP water for $48 \mathrm{~h}$ with MWCO 3500 membrane to remove $\mathrm{Na}_{2} \mathrm{CO}_{3}$, the dialysis water was replaced of the fresh every $8 \mathrm{~h}$. After 
freeze-drying, the solid was dissolved in cold PBS (pH 9.0), and store in $4{ }^{\circ} \mathrm{C}$ overnight. After that, the precipitation was filtered off, and the filtrate was dialyzed against UP water for $48 \mathrm{~h}$ with MWCO 3500 membrane to remove salt again. After freeze-drying, the DDCPc was collected with yield $26.7 \% .{ }^{1} \mathrm{H} \mathrm{NMR}\left(500 \mathrm{MHz}, \mathrm{CDCl}_{3}\right): 4.66\left(\mathrm{t},-\mathrm{COOCH}_{2} \mathrm{CH}_{2}-\mathrm{N}^{+}\right)$, $4.58\left(\mathrm{~m},-\mathrm{COOCH}_{2} \mathrm{CH}(\mathrm{OOC}-) \mathrm{CH}_{2}-\mathrm{NH}-\right), 4.20\left(\mathrm{~m},-\mathrm{COOCH}_{2} \mathrm{CH}(\mathrm{OOC}-) \mathrm{CH}_{2}-\mathrm{NH}-\right), 4.03-4.13$ (m, $\left.-\mathrm{CH}_{2} \mathrm{CH}_{2}-\mathrm{PO}_{4}{ }^{-}-\mathrm{CH}_{2} \mathrm{CH}_{2}-\right), 3.74\left(\mathrm{~m},-\mathrm{CH}_{2} \mathrm{~N}^{+} \mathrm{CH}_{2}-\right)$, $3.39\left(\mathrm{~s}, \mathrm{~N}^{+}-\left(\mathrm{CH}_{3}\right)_{2}\right), 3.08\left(\mathrm{~m},-\mathrm{CH}_{2}-\right.$ $\mathrm{NH}-\mathrm{CH}_{2-}$ ), 2.55 (m, - $\mathrm{NHCH}_{2} \mathrm{CH}_{2} \mathrm{COO}-,-\mathrm{PO}-\mathrm{CH}_{2} \mathrm{CH}_{2} \mathrm{C} \equiv \mathrm{CH}$ ), 2.31 (t, - $\left.\mathrm{CH}_{2} \mathrm{CH}_{2} \mathrm{COO}-\right)$, 2.13 (s, - $\left.\mathrm{PO}-\mathrm{CH}_{2} \mathrm{CH}_{2} \mathrm{C} \equiv \mathrm{CH}\right), 1.59$ (m, - $\left.\mathrm{CH}_{2} \mathrm{CH}_{2} \mathrm{COO}-\right), 1.25\left(\mathrm{~m}, \mathrm{CH}_{3}\left(\mathrm{CH}_{2}\right)_{8} \mathrm{CH}_{2}-\right), 0.87$ (t, $\left.\mathrm{CH}_{3}\left(\mathrm{CH}_{2}\right){ }_{10} \mathrm{CH}_{2}-\right) ;{ }^{31} \mathrm{P} \mathrm{NMR}\left(500 \mathrm{MHz}, \mathrm{CDCl}_{3}\right): \delta(\mathrm{ppm}) 0.68$ (s). HR-ESI-mass spectrum calculated for $\mathrm{C} 40 \mathrm{H} 75 \mathrm{~N} 2 \mathrm{O} 10 \mathrm{P} 775.02$, found $775.52(\mathrm{M}+\mathrm{H}), 797.50(\mathrm{M}+\mathrm{Na})$.

Synthesis of Folate-CP. To determine the excellent bioorthogonality of CP lipids, folate has been chosen as a model and conjugated to CP lipids in situ using a 'click' reaction. Briefly, folate-PEG-azide $(0.02 \mathrm{mmol})$, bpy $(0.02 \mathrm{mmol})$ and DMCP-c $(0.02 \mathrm{mmol})$ were dissolved into $5 \mathrm{~mL}$ solution (chloroform : methanol, $\mathrm{v} / \mathrm{v}, 4: 1$ ) with stirring. The mixture was degassed by three exhausting/refilling dry nitrogen cycles, and then the $\mathrm{CuBr}(0.1 \mathrm{mmol})$ was added under the nitrogen. After reaction for $36 \mathrm{~h}$, the solution was diluted with water and dialyzed against water with $24 \mathrm{~h}$ to remove the excessive catalyst and unreacted materials. After lyophilized, the final product folate-CP was obtained with yield $46.7 \%$. 


\section{Characterization}

NMR spectra were obtained Via Unity-500 NMR spectrometer. The size distribution of these liposomes in aqueous medium was tested by dynamic light scattering (DLS) (Zetasizer Nano-ZS, Malvern Instruments). The morphology of these liposomes was recorded via transmission electron microscopy (TEM) (JEOL JEM-1011 electron microscope). The phase transition temperature $\left(T_{m}\right)$ was determined via differential scanning calorimetry (DSC) (MC-DSC4100, Calorimetry Sciences Corp.). The Dox content loaded in theliposomes was determined by UV-vis spectroscopy (NanoDrop 2000c, Thermo Scientific). The fluorescence images were recorded via confocal laser scanning microscopy (CLSM) (LSM 700 Carl Zeiss Microscopy). The internalization efficiency was obtained via flow cytometry (FACS) (Guava easyCyte 6-2L, Milipore), the excitation and emission were $480 \mathrm{~nm}$ and $560 \mathrm{~nm}$, respectively. In addition, the cell viability was tested via synergy microplate reader (Synergy H1 Microplate Reader, BioTek).

Differential scanning calorimetry (DSC) tests. The process of thin film was hydrated to liposomes was conducted around the phase transition temperature $\left(T_{m}\right)$, thus $T_{m}$ is key parameter for preparation of liposomes. Here, the $T_{m}$ for DPPC, DPCA, DMCA, DDCA, DPCP, DCP, and DDCP was determined via DSC (MC-DSC4100, Calorimetry Sciences Corp.). Data were obtained over a range of $10-110^{\circ} \mathrm{C}$ at $5^{\circ} \mathrm{C} / \mathrm{min}$ with a heat-cool-heat cycle, and last heat cycle data was recorded. 


\section{Preparation of the choline phosphate liposomes and determination of DLE and DLC.}

Liposomes were prepared via the thin film hydration. ${ }^{1}$ Briefly, the DPCP, DMCP and DDCP lipids (40 mg, respectively) were dissolved in $5 \mathrm{~mL}$ mixed solution (chloroform: methanol, $4: 1, \mathrm{v} / \mathrm{v})$, then cholesterol $(20 \mathrm{mg})$ was added. After completely dissolved, the solution was dried via vacuum distillation using rotary evaporator at $50^{\circ} \mathrm{C}$ for $4 \mathrm{~h}$ to make thin film in $100 \mathrm{~mL}$ flask. Then, $5 \mathrm{~mL}$ UP water or PBS was added. The solution was sonicated at $60{ }^{\circ} \mathrm{C}$ for 15 minutes, and filtered five times through polycarbonate membrane (pore size: $200 \mathrm{~nm}$ ) to prepare blank liposomes. Then, the liposomes solution was dialyzed against PBS for $24 \mathrm{~h}$ to obtain final liposomes. The liposomes solution was determined via DLS and TEM. In brief, the TEM images of DPPC, DDCP-c, DMCP-c and DPCP-c liposomes were collected at first. The diameter of liposomes about 300 each group was measured in TEM images via Size Analysis Software, and then was analyzed via Origin Software to obtain the size distribution graphs.

Doxorubicin(Dox)-loaded choline phosphate liposomes was prepared via $\left(\mathrm{NH}_{4}\right)_{2} \mathrm{SO}_{4}$ concentration method. ${ }^{2}$ Briefly, the choline phosphate thin film was prepared according to above-mentioned method. Then, $5 \mathrm{~mL}\left(\mathrm{NH}_{4}\right)_{2} \mathrm{SO}_{4}$ solution $(300 \mathrm{mM})$ was added, and sonicated at $60^{\circ} \mathrm{C}$ for 15 minutes. The liposomes containing solution was filtered five times through polycarbonate membrane (pore size: $200 \mathrm{~nm}$ ). After that, the solution was dialyzed (MCW: 3500) against $200 \mathrm{~mL}$ PBS for $4 \mathrm{~h}$. Subsequently, these liposomes were incubation with Dox at $60{ }^{\circ} \mathrm{C}$ for 15 min. Finally, the unloaded Dox was removed via dialyzed (MCW: 
3500) against $200 \mathrm{~mL}$ PBS for $6 \mathrm{~h}$, the dialysate was replaced every $3 \mathrm{~h}$. Amount of solution was taken out lyophilizing to detect the drug loading content (DLC) and drug loading efficiency (DLE). In brief, after lyophilization, $1 \mathrm{mg}$ powder was dissolved in $1 \mathrm{~mL}$ water, and then, the concentration of Dox was measured via UV-vis spectra according the Dox calibration curve.

Preparation of the DPPC liposomes. DPPC Liposomes were prepared according to above-mentioned method, and made some changes. Briefly, the DPPC, (40 mg, respectively) was dissolved in $5 \mathrm{~mL}$ mixed solution (chloroform: methanol, 4:1, v/v), then cholesterol (20 mg) was added, and the solution was dried via vacuum distillation using rotary evaporator at $40^{\circ} \mathrm{C}$ for $3 \mathrm{~h}$ to make thin film in $100 \mathrm{~mL}$ flask. Then, $5 \mathrm{~mL}$ UP water or PBS was added. The solution was sonicated at $50^{\circ} \mathrm{C}$ for 15 minutes, and filtered five times through polycarbonate membrane (pore size: $200 \mathrm{~nm}$ ) to prepare blank liposomes. The liposomes solution was detected via DLS and TEM.

Doxorubicin (Dox)-loaded choline phosphate liposomes was prepared via the same method. Briefly, the DPPC thin film was prepared at first. Then, $5 \mathrm{~mL}\left(\mathrm{NH}_{4}\right)_{2} \mathrm{SO}_{4}$ solution (300 mM) was added, and sonicated at $60{ }^{\circ} \mathrm{C}$ for 15 minutes. The liposomes containing solution was filtered five times through polycarbonate membrane (pore size: $200 \mathrm{~nm}$ ). After that, the solution was dialyzed (MCW: 3500) against $200 \mathrm{~mL}$ PBS for $4 \mathrm{~h}$. Subsequently, these liposomes were incubation with Dox at $60^{\circ} \mathrm{C}$ for $15 \mathrm{~min}$. Finally, the unloaded Dox 
was removed via dialyzed (MCW: 3500) against $200 \mathrm{~mL}$ PBS for $6 \mathrm{~h}$, the dialysate was replaced every $3 \mathrm{~h}$.

Dependence of zeta potential and size of liposomes on variation in pH. DPPC, DPCP, DMCP and DDCP liposomes were prepared with concentration of $8 \mathrm{mg} / \mathrm{mL}$ lipids in UP water. Then, the liposomes were diluted to various $\mathrm{pH}$ solution $(\mathrm{pH} 1.0,2.0,5.0,7.4,9.0$, $11.0,13.0)$ (concentration of $1 \mathrm{mg} / \mathrm{mL}$ lipids). The zeta potential and size of these liposomes in various $\mathrm{pH}$ were determined via DLS.

\section{Dependence of zeta potential and size of liposomes on variation in $\mathrm{NaCl}$} concentrations. Similarly, DPPC, DPCP, DMCP and DDCP liposomes were prepared with concentration of $8 \mathrm{mg} / \mathrm{mL}$ lipids in UP water. Then, the liposomes were added to various $\mathrm{NaCl}$ concentrations solution $(0 \mathrm{M}, 0.0375 \mathrm{M}, 0.075 \mathrm{M}, 0.15 \mathrm{M}, 0.30 \mathrm{M}, 0.60 \mathrm{M})$ (concentration of $1 \mathrm{mg} / \mathrm{mL}$ lipids). The zeta potential and size of these liposomes in various $\mathrm{NaCl}$ concentrations solution were determined via DLS.

UV-vis spectroscopy of liposomes. DPPC, DPCP, DMCP and DDCP liposomes and Dox-loaded liposomes were prepared via similar method. Then, the liposomes were diluted to suitable concentration using UP water, and determined via UV-vis spectroscopy (NanoDrop 2000c, Thermo Scientific).

Hemolysis assay. The assay was conducted according to previous method. ${ }^{3}$ In brief, fresh mouse blood was collected from heart, and the red blood cells (RBCs) were washed 
three times with PBS. After that, the RBCs were diluted and suspended with $10 \mathrm{~mL}$ PBS.

First, $0.3 \mathrm{~mL}$ RBCs suspension was mixed with $1.2 \mathrm{~mL}$ PBS as negative control group, and with $1.2 \mathrm{~mL}$ water as positive control group. Various lipids dissolved in $1.2 \mathrm{~mL}$ PBS with different concentrations were added to the RBCs suspension $(0.3 \mathrm{~mL})$, and then incubated for $2 \mathrm{~h}$ at $37^{\circ} \mathrm{C}$. Finally, the samples were centrifuged with $12000 \mathrm{r} / \mathrm{min}$ for $10 \mathrm{~min}$, the supernatant was collected and measured the absorbance intensity at $541 \mathrm{~nm}$ with microplate spectrophotometer. The percent hemolysis was calculated according to the following equation.

$$
\text { Percent hemolysis }(\%)=\frac{\text { absorbance intensity of samples }}{\text { absorbance intensity of positive control }} \times 100 \%
$$

\section{In vivo biocompatibility assessment via blood biochemistry and hematology of mice.}

The biocompatibility of choline phosphate lipids in vivo was evaluated via female KM mice (purchased from Center for Experimental Animals, Jilin University, 18-24 g, 4-6 weeks old), according to previous methods. ${ }^{2-3}$ The mice were injected with PBS, DPCP, DMCP, DDCP and DPPC liposomes with concentration of $7 \mathrm{mg} / \mathrm{mL}(0.2 \mathrm{~mL}$ liposomes solution for each mouse) via tail vein. After injected for 10 days, fresh heart blood samples (0.5-1.0 mL each mouse) were obtained from each mouse. The blood samples $(0.2 \mathrm{~mL})$ were centrifuged at 4, $000 \mathrm{rpm}$ for $10 \mathrm{~min}$, and supernatant was collected for serum biochemistry study. The residual of whole blood was reserved in potassium EDTA collection tube for hematology analysis. The serum biochemistry analysis evaluation including alanine aminotransferase 
(ALT), Creatinine (Cre), alkaline phosphatase (ALP), aspartate aminotransferase (AST), blood urea nitrogen (BUN) albumin (ALB), and Total Protein (TP). In addition, the hematology analysis parameters including white blood cells count (WBC), red blood cells count (RBC), hemoglobin (HGB), \% of lymphocyte (Lym\%), \% of neutrophils (Neu\%), \% of monocyte (Mon\%), \% basophil (Bas\%) and \% eosinophil (Eos\%). All animal studies were performed in Center for Experimental Animals, Jilin University, and the procedures involving experimental animals were in accordance with protocols approved by the Committee for Animal Research of Jilin University, China.

In vivo drug release behavior. The Dox release behaviors from liposomes were conducted via dialysis method. In brief, $1 \mathrm{~mL}$ Dox-loading liposomes (DPPC, DDCP-c, DMCP-c, DPCP-c and Folate-DCP drug loading liposomes, respectively) was transferred into dialysis bag (MCW:3500), and immersed in $9 \mathrm{~mL}$ PBS with continuous stirring at 37 ${ }^{\circ} \mathrm{C}$. At fixed time intervals, $1 \mathrm{~mL}$ dialysis solution outside the bag was collected to determine the Dox concentration via UV-Vis spectra, and $1 \mathrm{~mL}$ fresh PBS was added after determination.

Cellular uptake detection via flow cytometry. The cellular uptake of different kind of Dox-loading liposomes was determined via flow cytometry. Mouse fibroblast cell line (NIH 3T3) and mouse mammary carcinoma cell line (4T1) were incubated in high glucose Dulbecco's modified Eagle's medium (DMEM) with 10\% fetal bovine serum (FBS), streptomycin $(100 \mu \mathrm{g} / \mathrm{mL})$ and 100 units $/ \mathrm{mL}$ of penicillin at cell incubator, respectively. Then, 
the cells were seeded in 12 well plates with the density of $2 \times 10^{5}$ cells per well. After incubation for 1 day, the medium was replaced of fresh medium containing different kinds of Dox-loading liposomes (the Dox concentration was $10 \mu \mathrm{g} / \mathrm{mL}$ ), respectively. Incubation for another $1 \mathrm{~h}$, discarded the medium, and washed the cells three times with PBS. Then, digested and collected the cells for flow cytometry tests.

Confocal Laser Scanning Microscopy (CLSM): NIH 3T3 and 4T1 cells were incubated in confocal dishes with the density of $1 \times 10^{5}$ cells. After incubation for 1 day, removed the medium and added fresh medium with different kinds of Dox-loading liposomes (the Dox concentration was $10 \mu \mathrm{g} / \mathrm{mL}$ ), respectively. Incubated another $1 \mathrm{~h}$, the medium was removed, and washed the cells with PBS three times. Then, $4 \%$ formaldehyde was added to fix cells at room temperature for $30 \mathrm{~min}$. After that, removed the medium, and added 4',6-diamidino-2-phenylindole (DAPI, $10 \mu \mathrm{g} / \mathrm{mL}$ ) to stain cell nuclei for $10 \mathrm{~min}$ at room temperature. Finally, the cells were washed three times with PBS and observed.

Cell viability assay: NIH $3 \mathrm{~T} 3$ and $4 \mathrm{~T} 1$ cells were incubated in 96 well plates with the density of $1 \times 10^{4}$ cells. After incubation for $24 \mathrm{~h}$, the medium was replaced of the fresh containing different kinds of Dox-loading liposomes with different Dox concentrations and blank liposomes, respectively. Then, the cells were incubated for $48 \mathrm{~h}, 10 \mu \mathrm{L}$ Celltiter-Blue reagent was added to each well. After incubated for another $4 \mathrm{~h}$, the cell viability was detected via microplate reader $\left(\lambda_{\mathrm{ex}}=560 \mathrm{~nm}, \lambda_{\mathrm{em}}=590 \mathrm{~nm}\right)$. The cell viability was calculated via following equation: 


$$
\text { cell viability }(\%)=\frac{\text { Fluorescent intensity }(\text { sample })}{\text { Fluorescent intensity }(\text { control })} \times 100 \%
$$

Pharmacokinetic experiments: 6-week-old SD mice were obtained to detect the pharmacokinetic of different kinds of CP liposomes and PC liposomes. Dox-loading liposomes in PBS were injected intravenously into mice tail vein with the Dox concentration of $5 \mathrm{mg} / \mathrm{kg}$ of mouse body weight ( $\mathrm{n}=4$ per group). At fixed time $(0,1,2,4,6,8,10,24$, 48h), the blood samples (100 $\mu \mathrm{L})$ were collected from retro-orbital plexus of eye, and heparin was added to prevent clotting. Then, the plasma was extracted with methanol (150 $\mu \mathrm{L}$ ) on the vortex mixer of $10 \mathrm{~min}$. After centrifuging for $5 \mathrm{~min}$ at $150000 \mathrm{~g}$, the supernatant $(100 \mu \mathrm{L})$ was collected. The concentration of Dox was analyzed via HPLC.

Animals and tumor model. Balb/c female mice (18-21 g, 4-6 weeks, purchased from Center for Experimental Animals, Jilin University), naked Balb/c female mice (18-21 g, 4-6 weeks, purchased from Vital River Company, Beijing, China) were used. All animal procedures were in accordance with the Animal Care and Use Committee of Northeast Normal University. 4T1 tumor was established via subcutaneous injection of $4 \mathrm{~T} 1$ cells. The tumor volume was calculated via the following equation: Volume $=0.5 \times a \times b^{2}$, where $a$ and $b$ were represented for length and width, respectively. The length and width of tumor were measured via Vernier caliper.

In vivo imaging. The accumulation of Dox at tumor and main organs was real-time determined via vivo imaging method in Maestro In Vivo Imaging System (Cambridge 
Research \& Instrumentation, Inc., USA). Different kind of Dox-loading liposomes were injected into $4 \mathrm{~T} 1$ tumor bearing nude mice via tail vein at the Dox dose of $5 \mathrm{mg} / \mathrm{kg}$ body weight. The NIR fluorescence images was obtained at 3, 6, 12, 24, 36, $48 \mathrm{~h}$ post-injection. Meanwhile, at the time points of $24,36,48 \mathrm{~h}$, parts of mice were sacrificed, and the tumor and main organs (heart, liver, spleen, lung, kidney) were excised for NIR fluorescence imaging.

In addition, we also determined the Dox accumulation via confocal laser scanning microscopy. Different kind of Dox-loading liposomes were injected into 4T1 tumor bearing nude mice via tail vein at the Dox dose of $5 \mathrm{mg} / \mathrm{kg}$ body weight. After injected for $6 \mathrm{~h}$, the mice were sacrificed. Then, the tumor was excised and sliced to observe via confocal laser scanning microscopy.

In vivo antitumor efficacy. The $4 \mathrm{~T} 1$ tumor-bearing mice were randomly divided into six groups and treated with different Dox-loading liposome formulations respective: 1 . saline; 2. Dox-loading DPPC liposomes; 3. Dox-loading DDCP liposomes; 4. Dox-loading DMCP liposomes; 5. Dox-loading DPCP liposomes; 6. Dox-loading Folate CP liposomes (Doxequivalent dose of $3 \mathrm{mg} / \mathrm{kg}$ body weight). These mice were treated at $1^{\text {st }}, 3^{\text {nd }}, 5^{\text {th }}$ day. The mice body weight and tumor volume were measured every other day. The treatment efficacy could be monitored via determine the relative changes of body weight and tumor volume. After 17 days, all mice were sacrificed, and the tumor and main organs (heart, liver, 
spleen, lung, kidney) were excised and fixed in 10\% neutral buffered formalin. Then stained via hematoxylin-eosin (H\&E) and TUNEL for pathological analysis. 


\section{NMR Spectra}

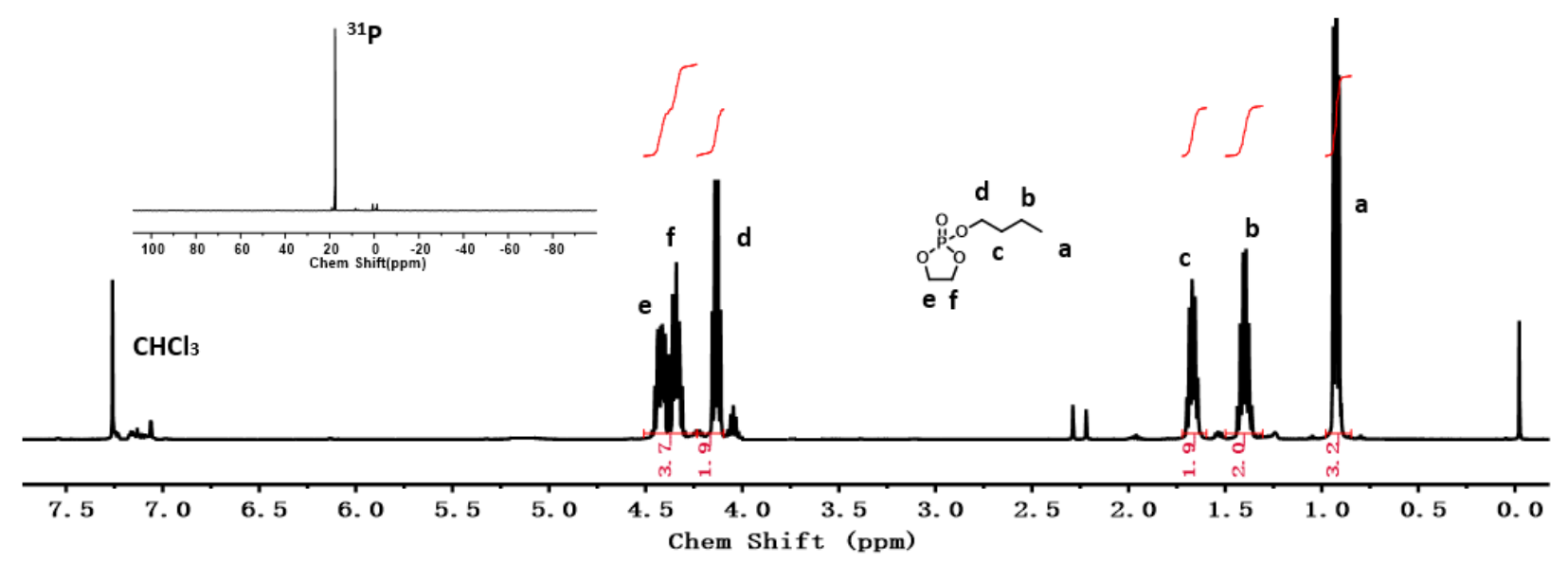

NMR Spectra 1

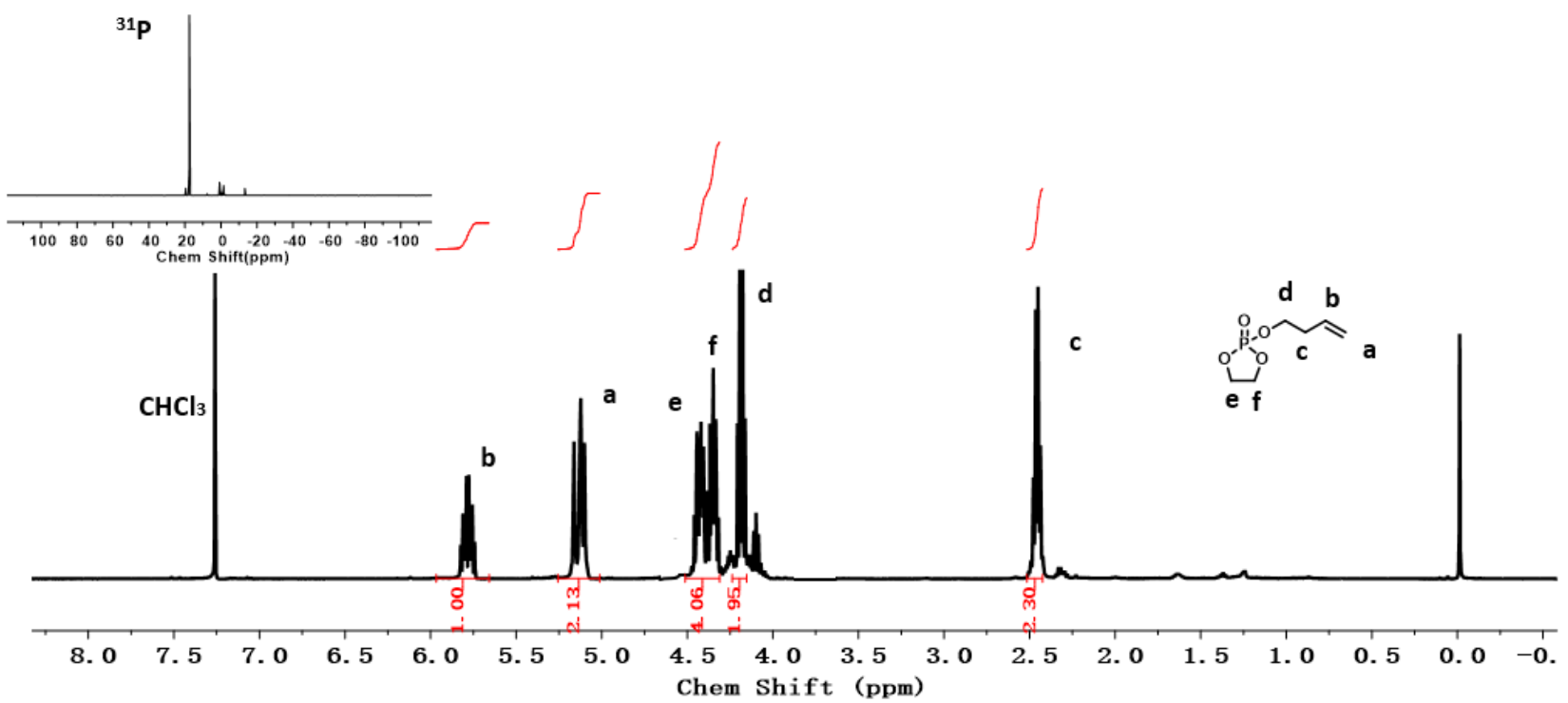

NMR Spectra 2 


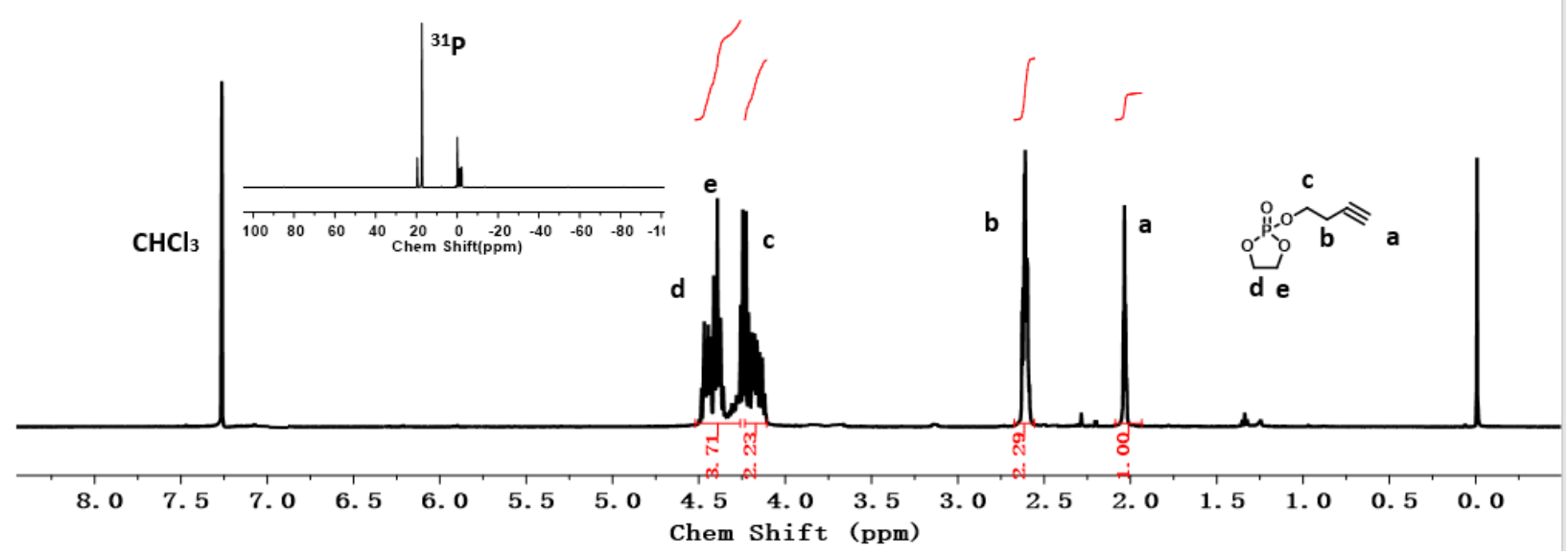

NMR Spectra 3

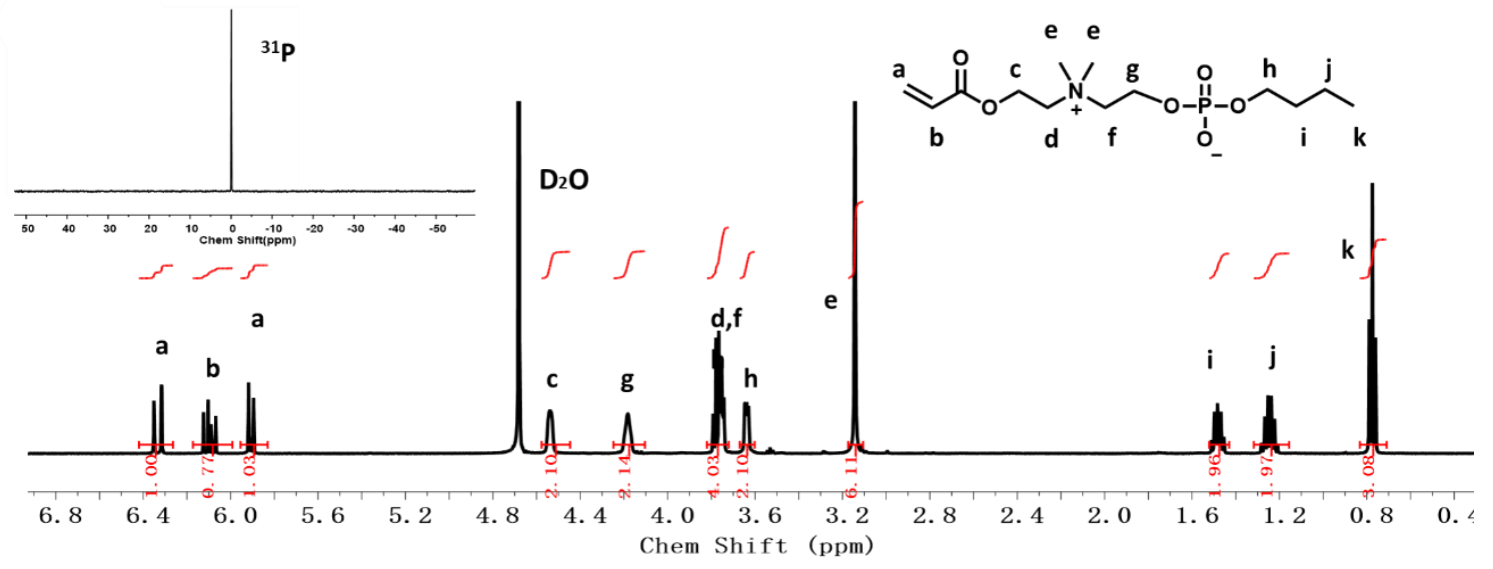

NMR Spectra 4

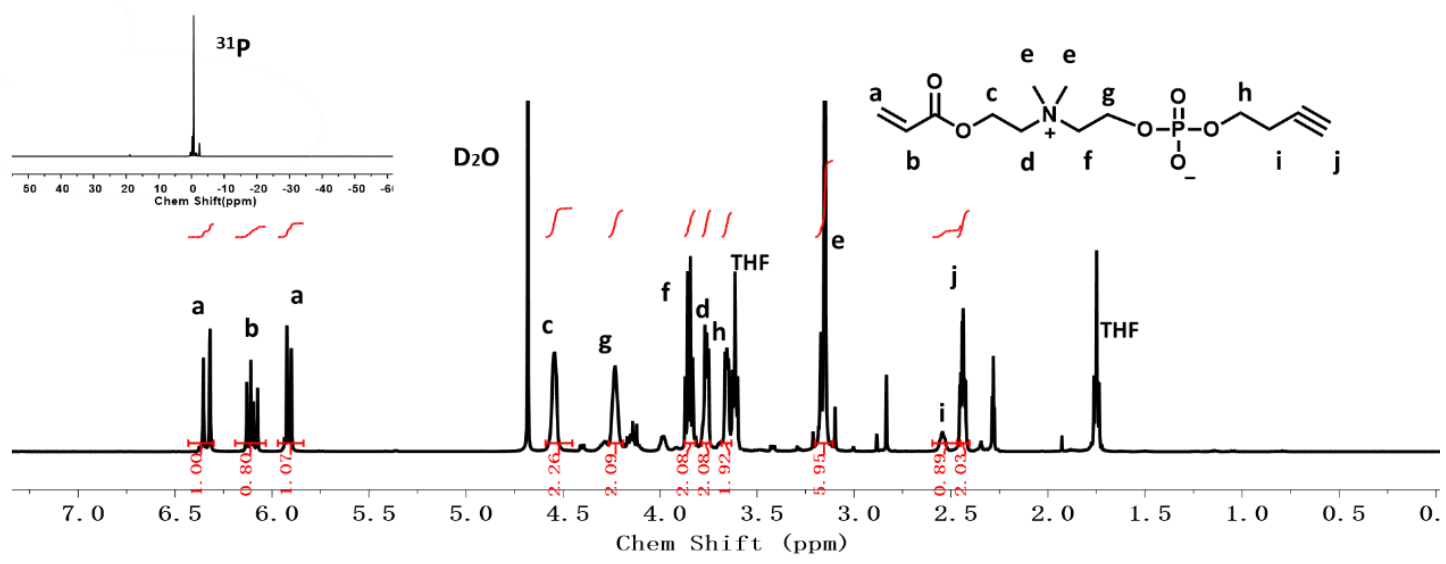

NMR Spectra 5

34 / 74 


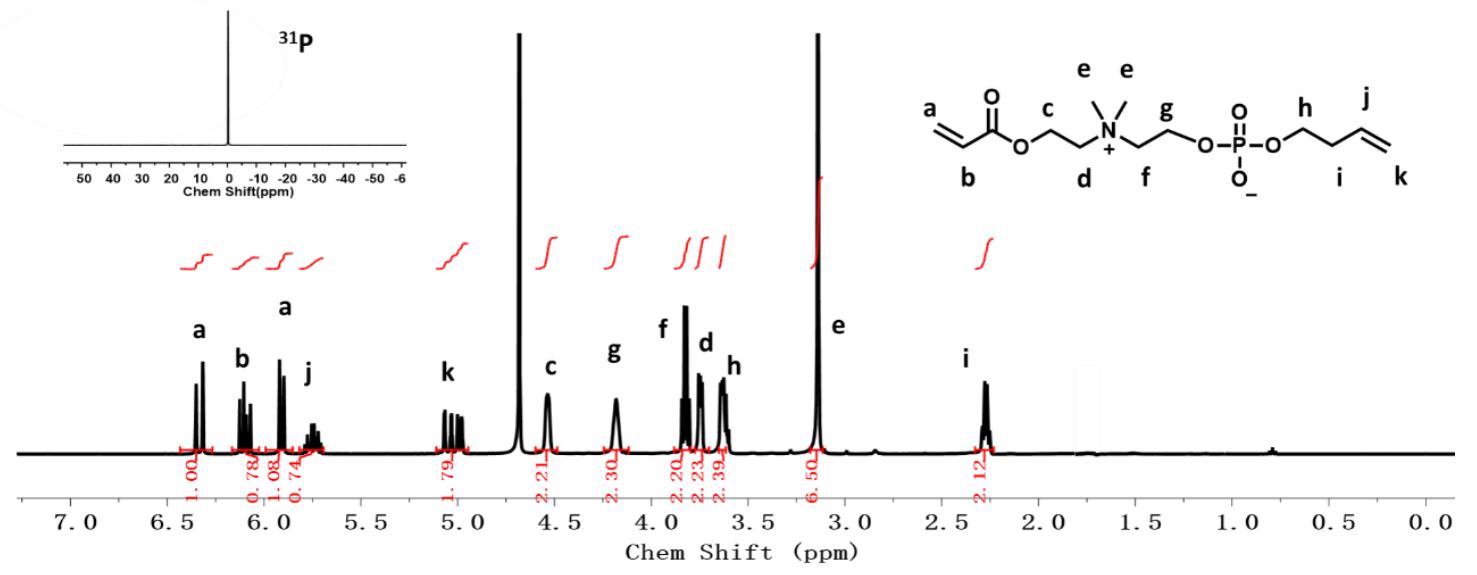

NMR Spectra 6

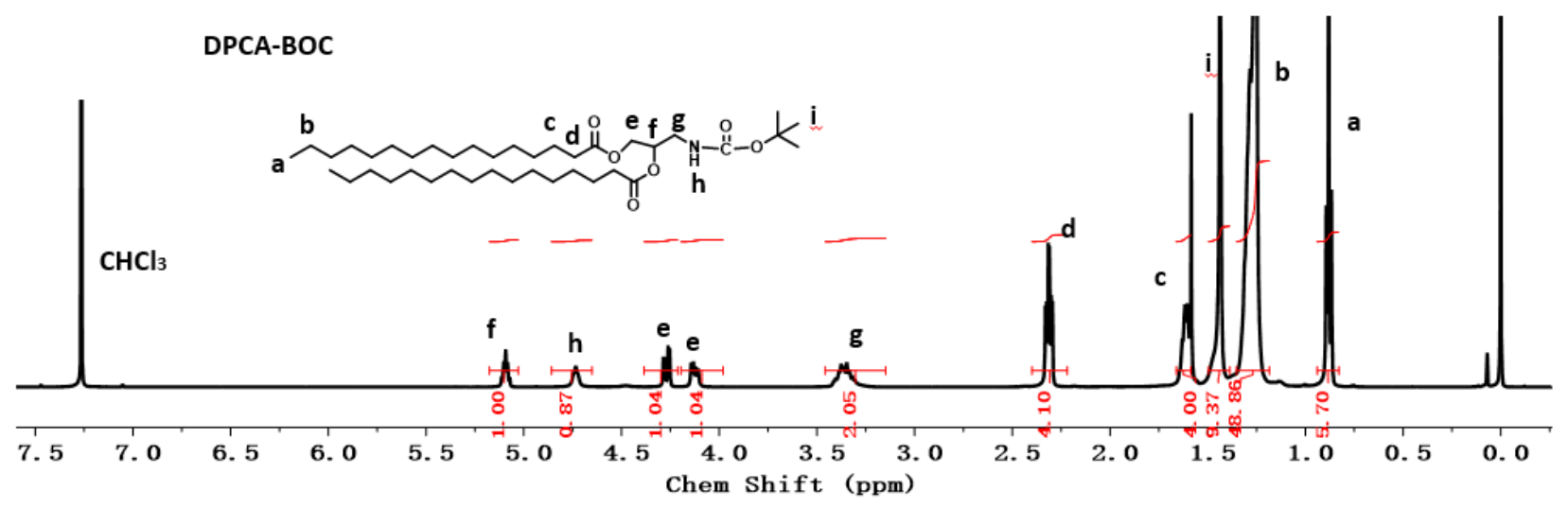

NMR Spectra 7 


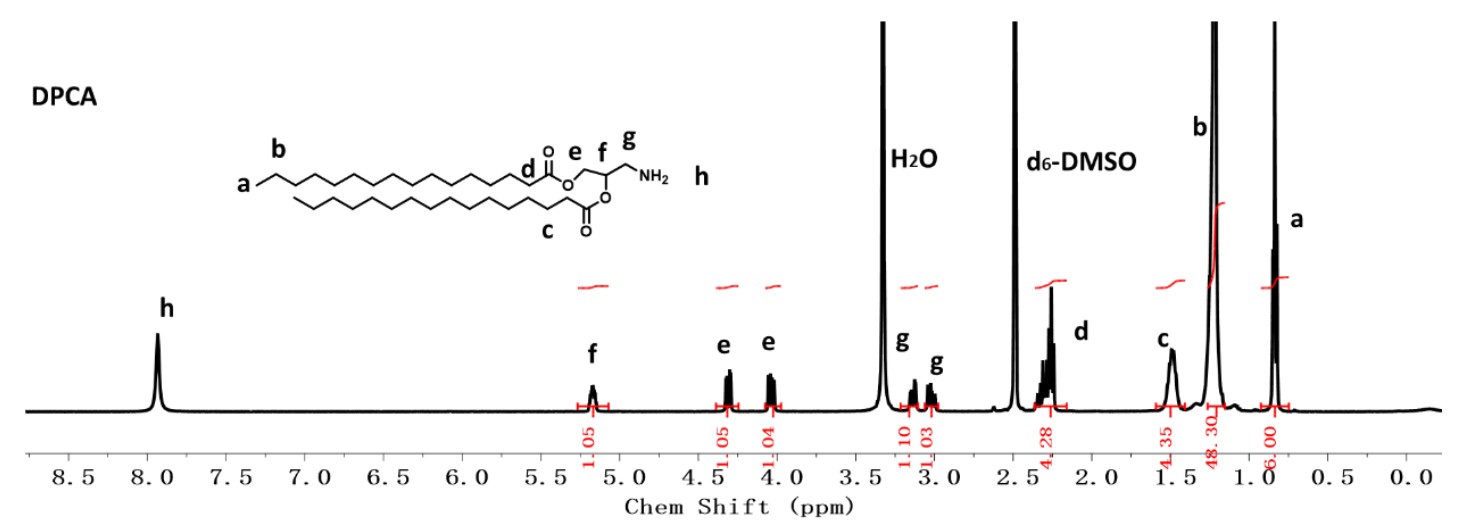

NMR Spectra 8

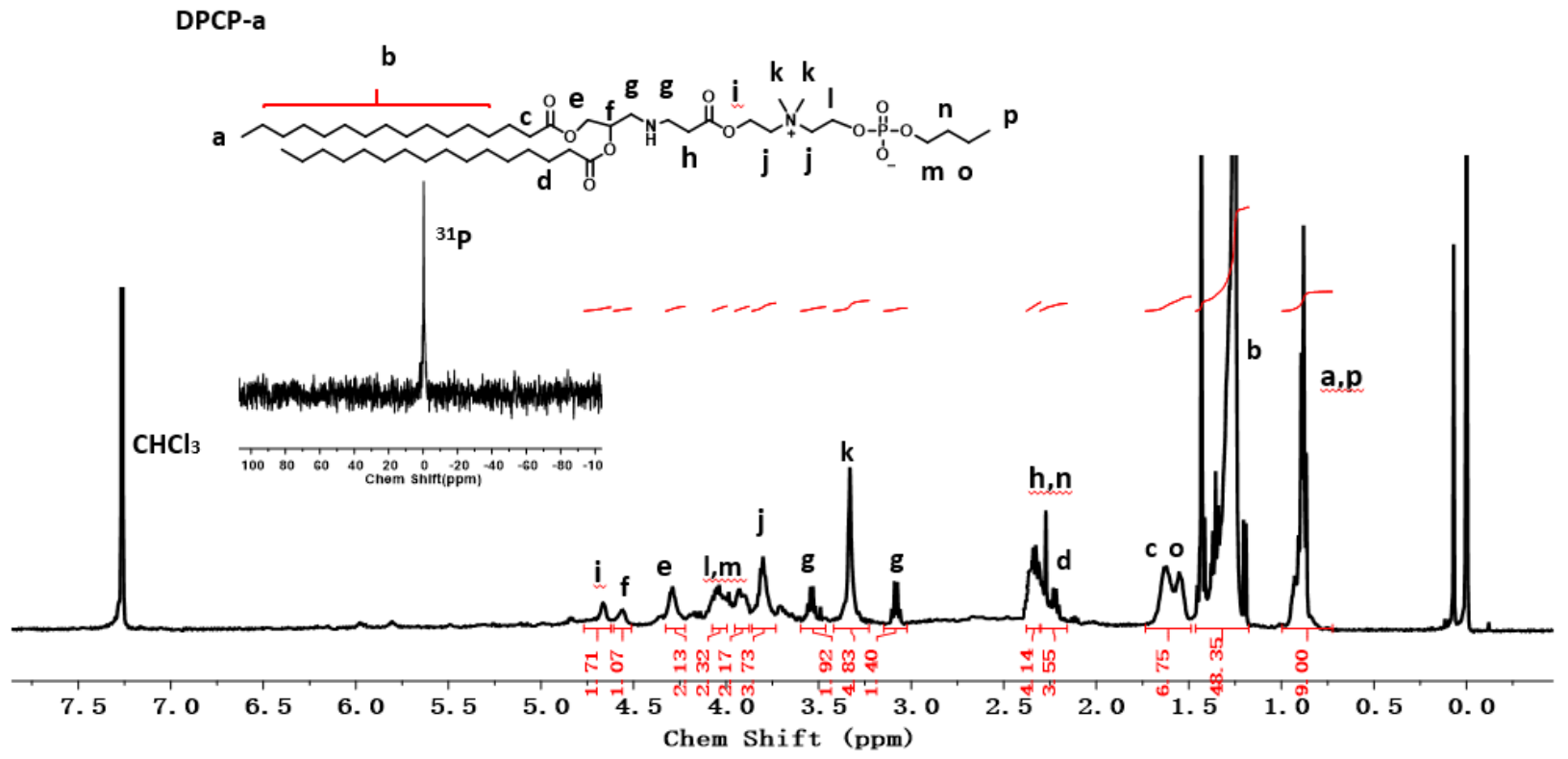

NMR Spectra 9 


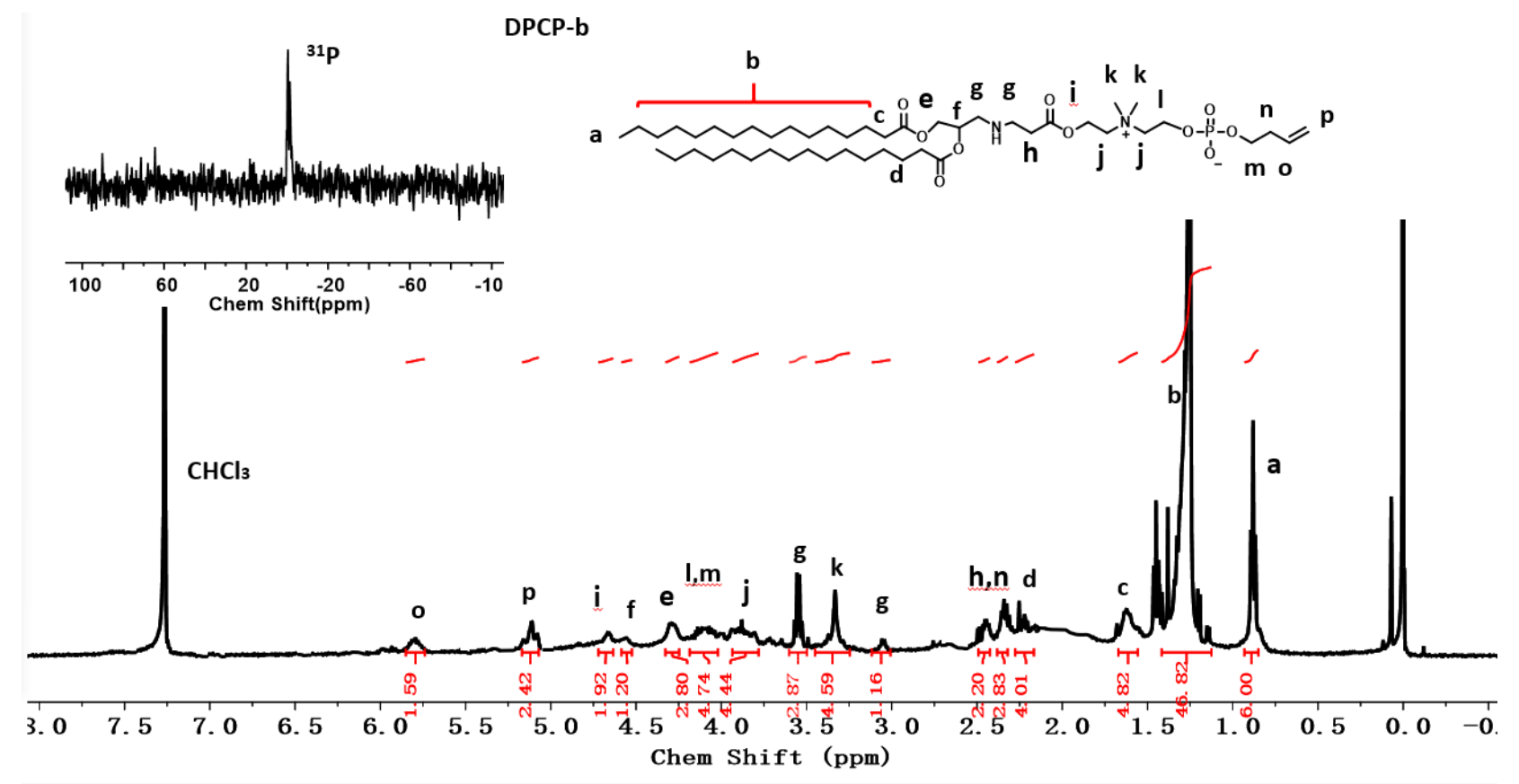

NMR Spectra 10

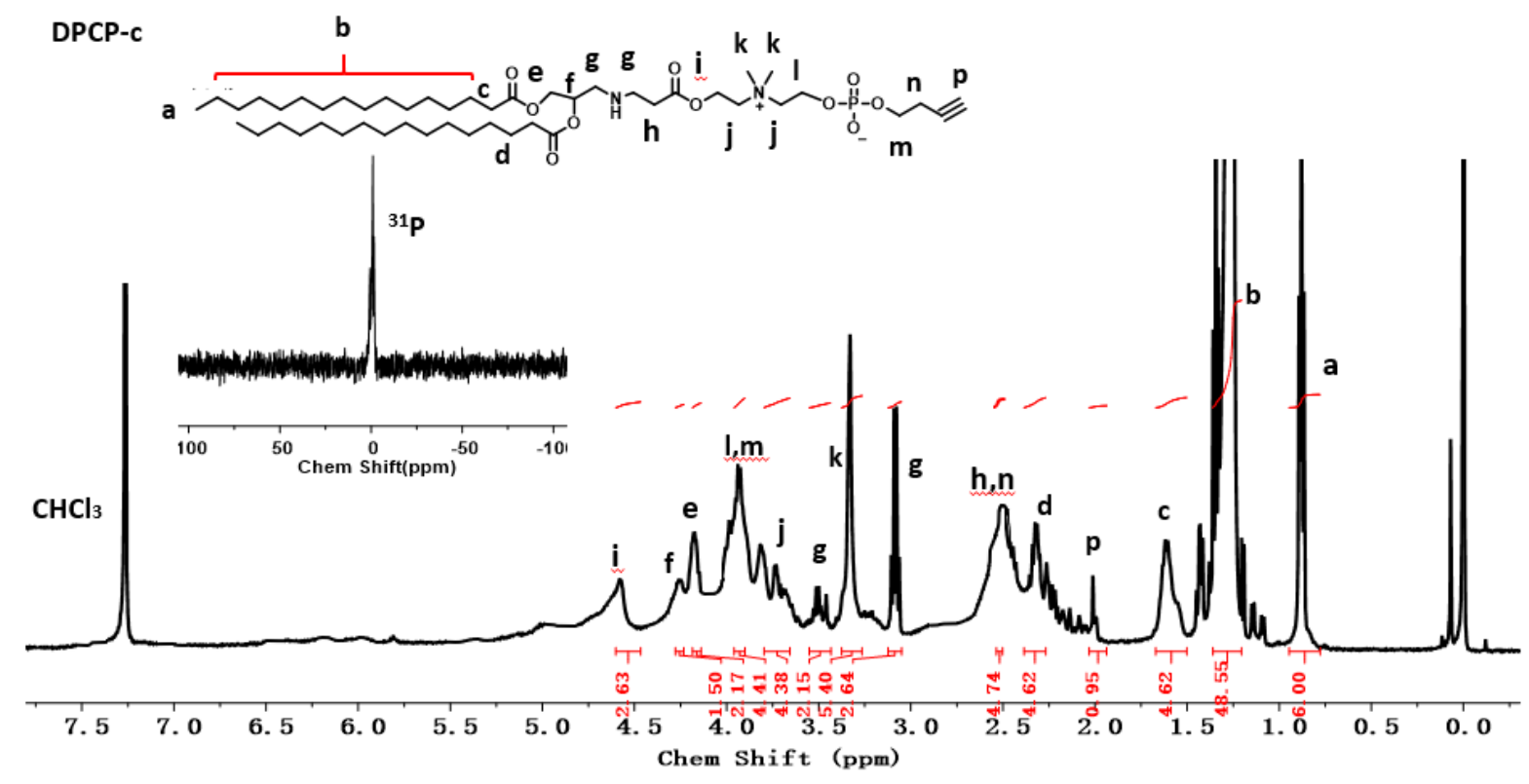

NMR Spectra 11 


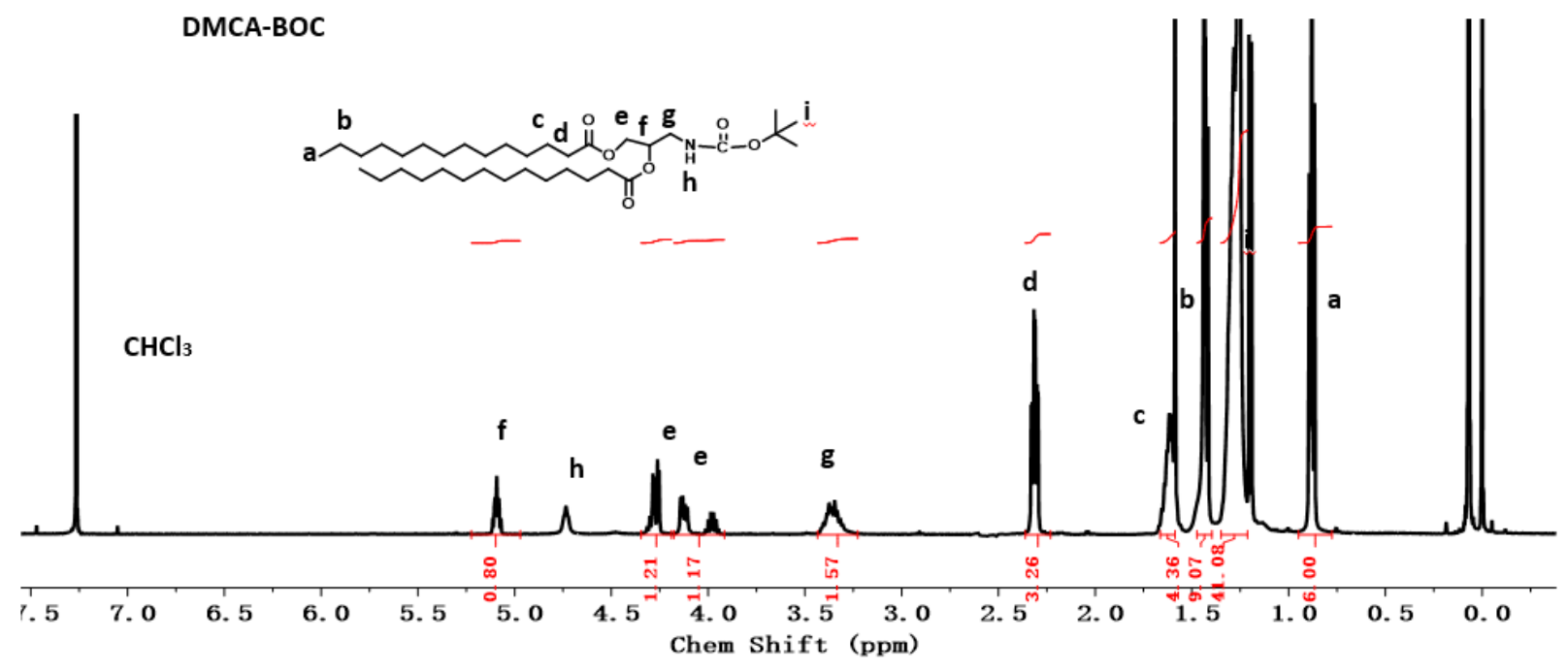

NMR Spectra 12

DMCA
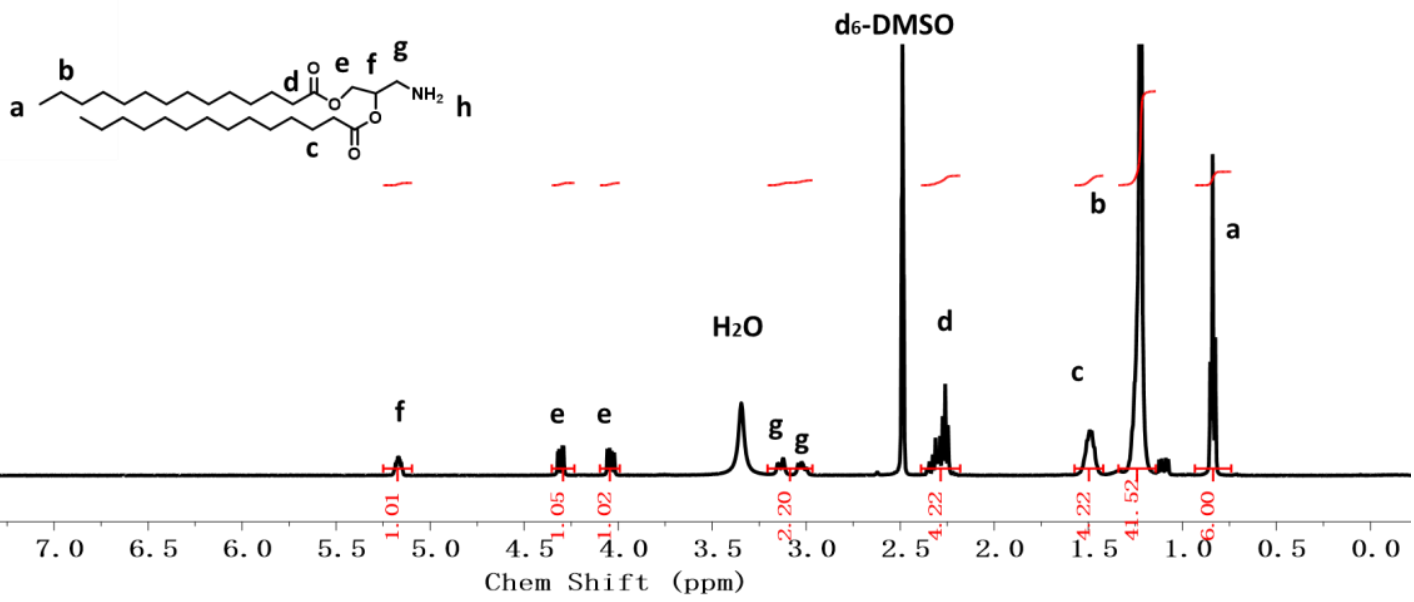

NMR Spectra 13 


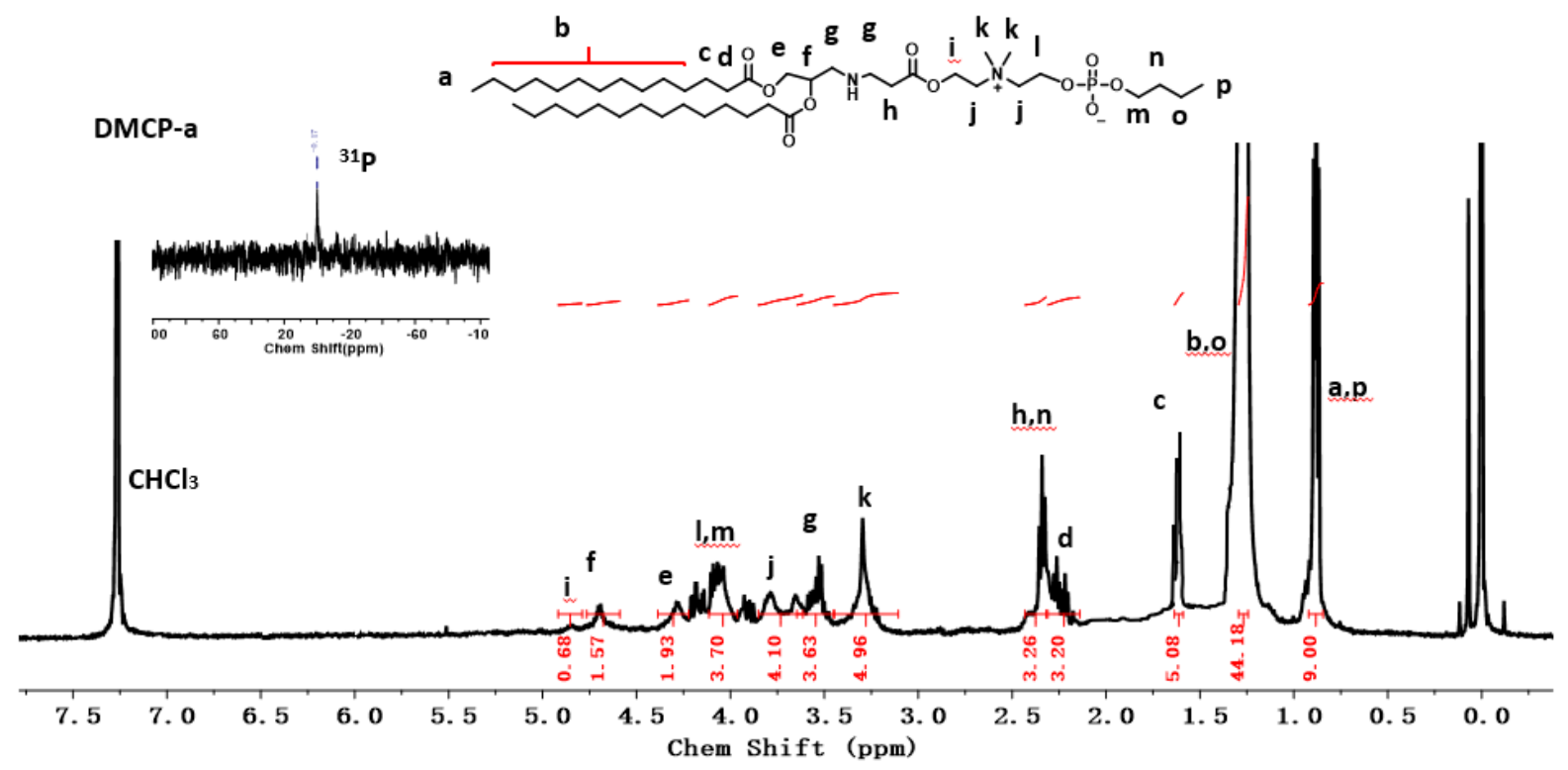

NMR Spectra 14

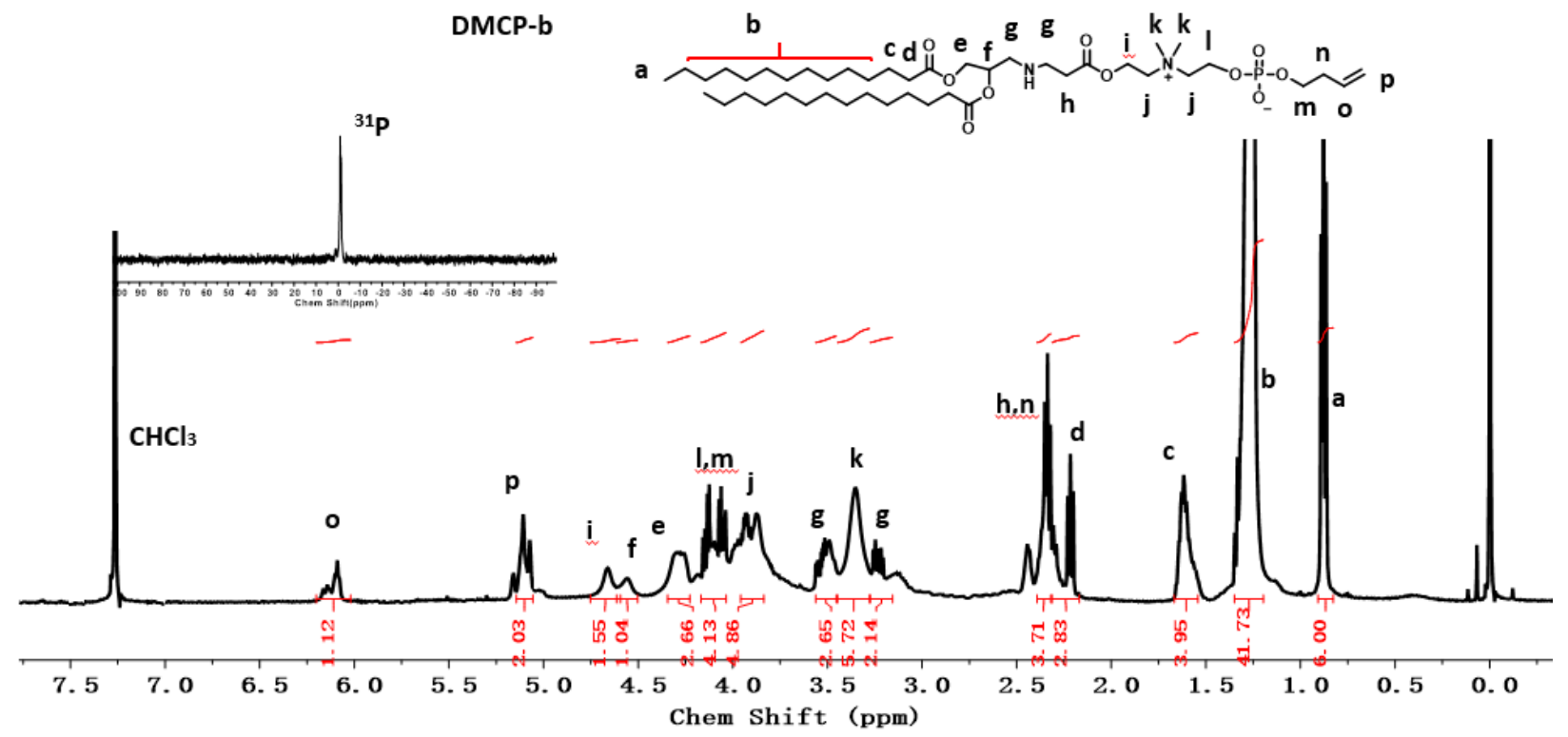

NMR Spectra 15 


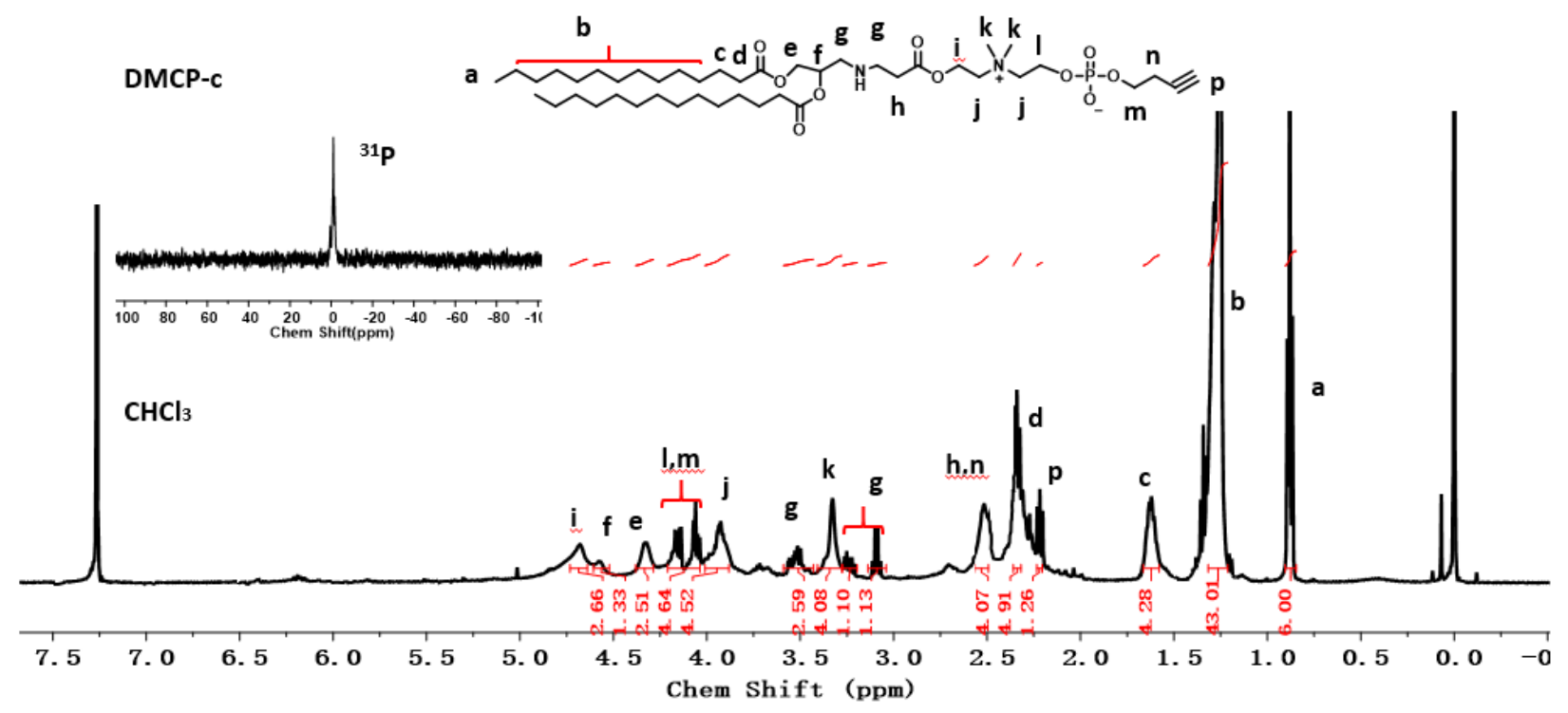

NMR Spectra 16



NMR Spectra 17 


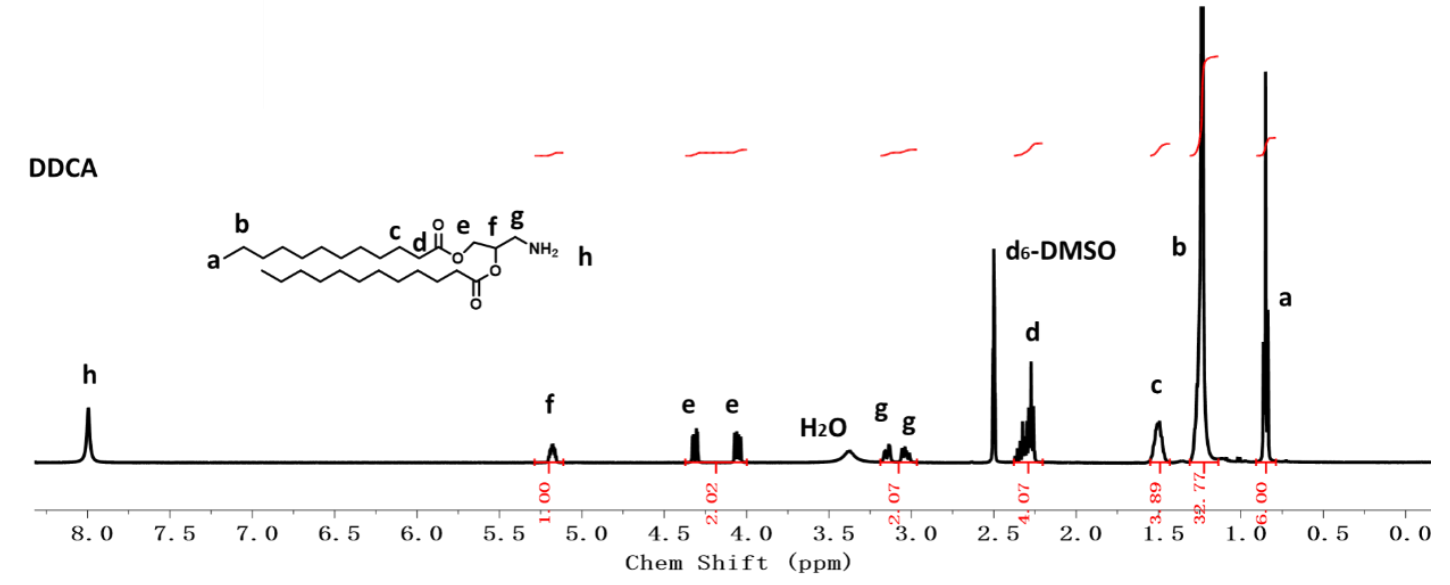

NMR Spectra 18

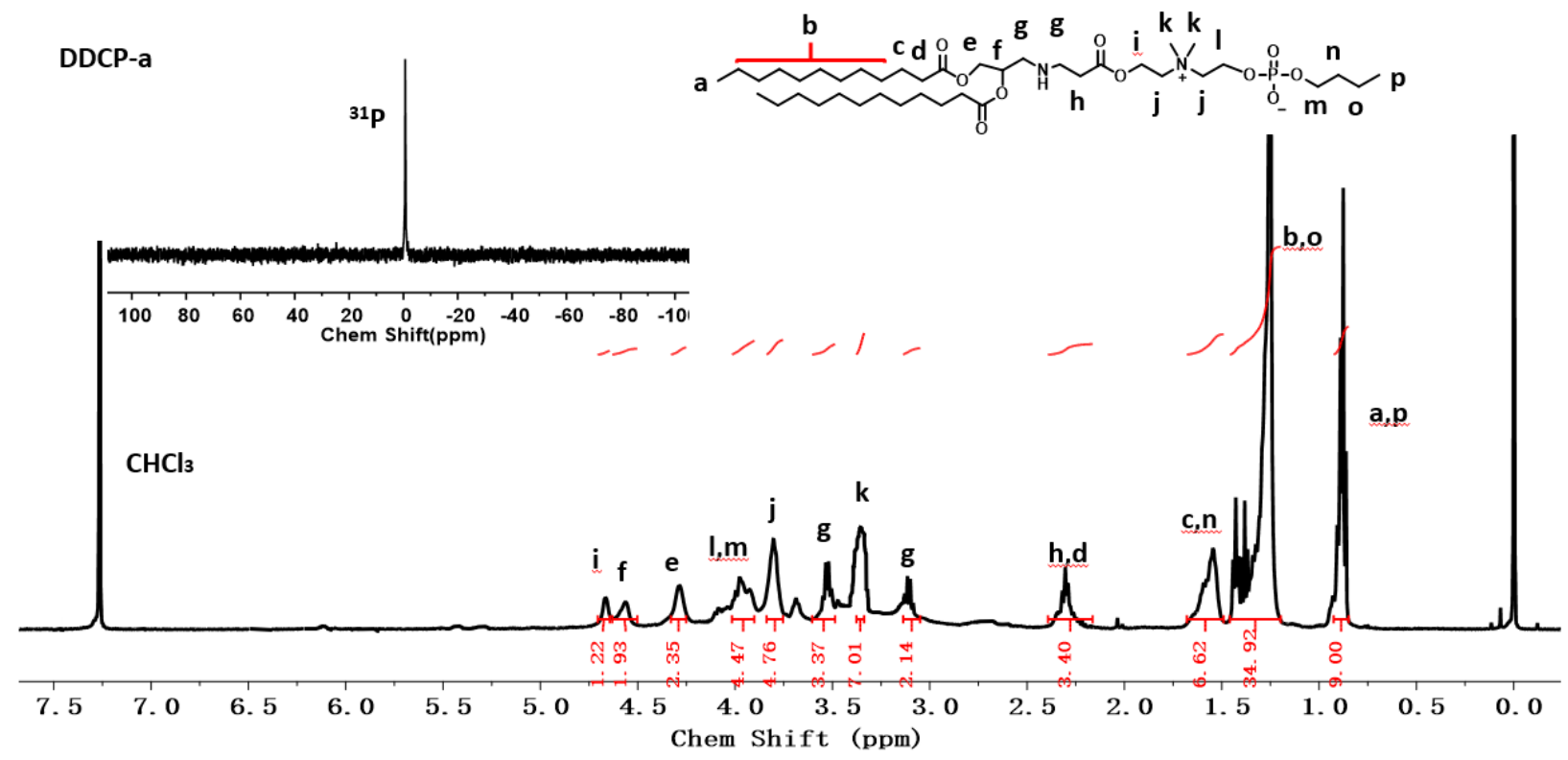

NMR Spectra 19 


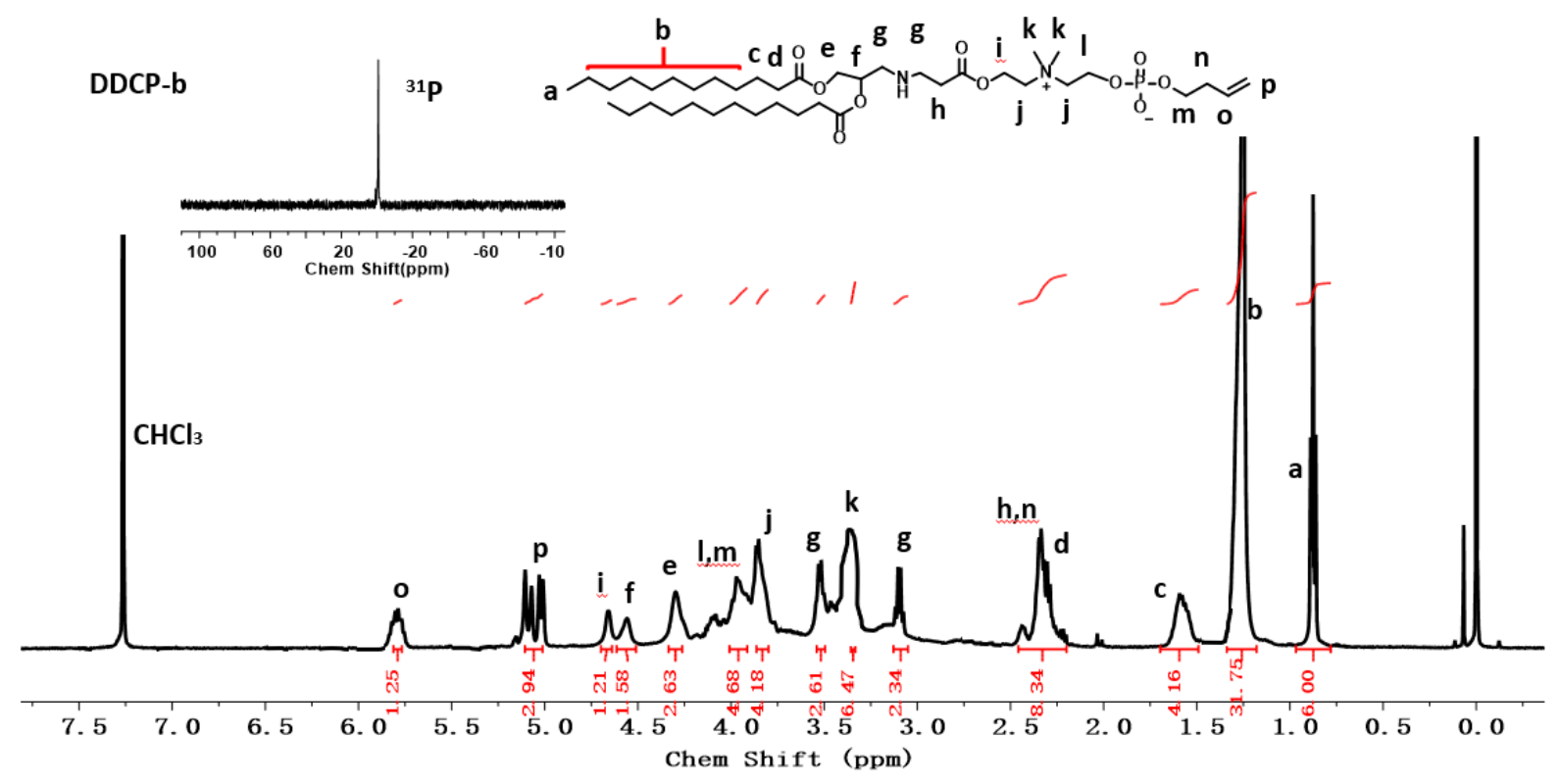

NMR Spectra 20



NMR Spectra 21 


\section{Mass spectra}

wWl-1_190424135607 \#68-69 RT: $0.92-0.93$ AV: 2 NL: 7.12E6

T: FTMS + pESI Full ms [100.00-1500.00]

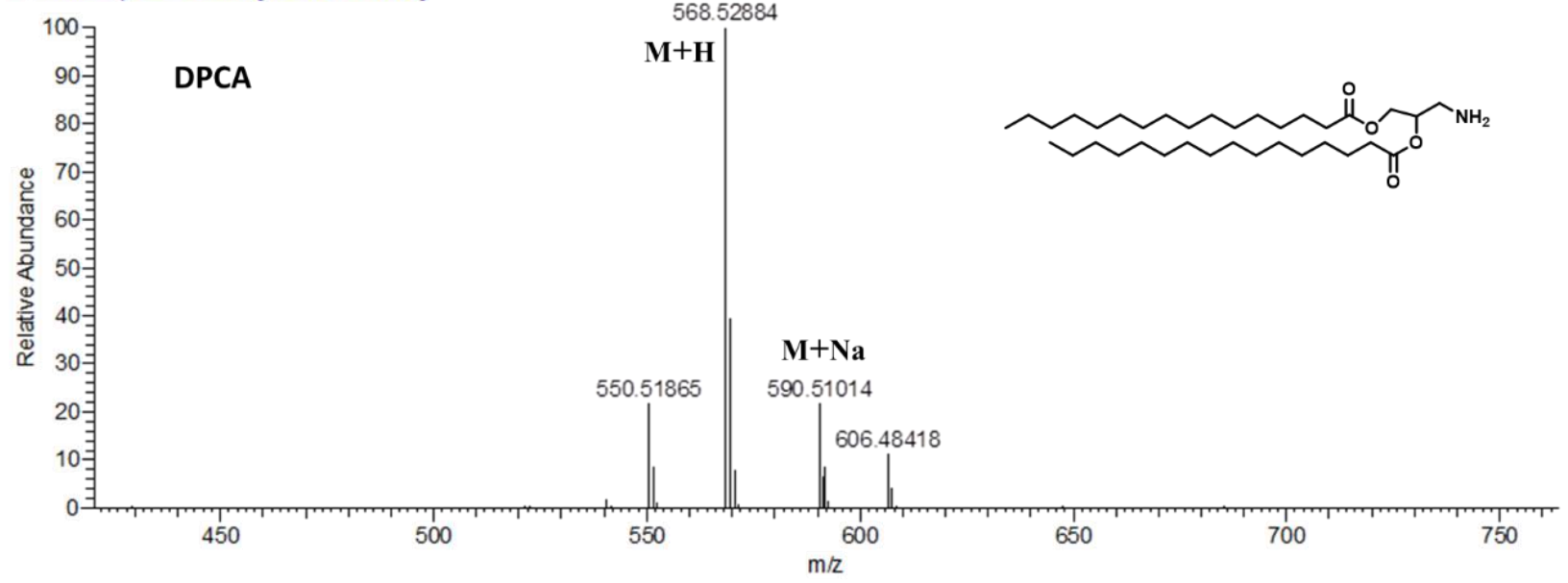

\section{Mass spectra 1}

DPCP-a

WWI-2_19042414033E \#36-37 RT: 0.48-0.49 AV: 2 NL' 3.88E5 T: FTM $\mathrm{M}+\mathrm{p}$ ESI Full ms [100.00-1500.00]

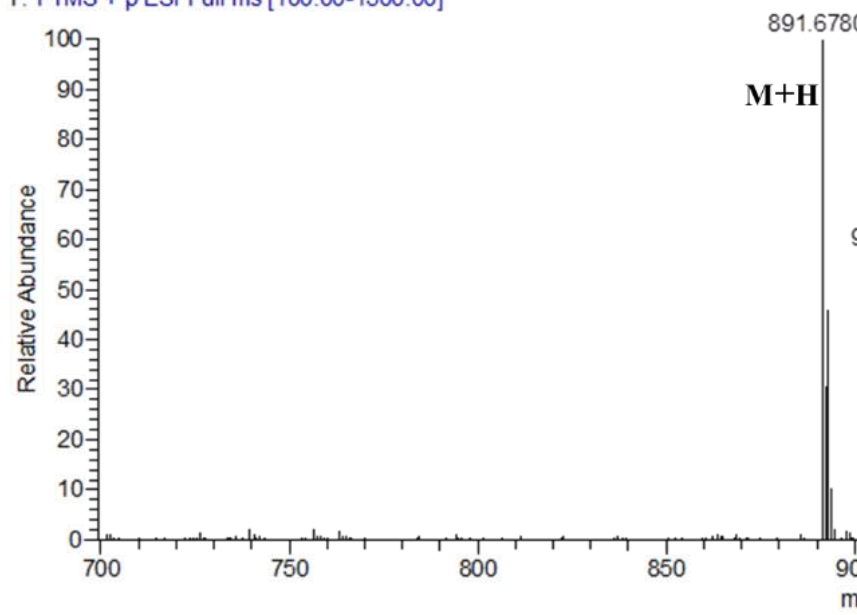

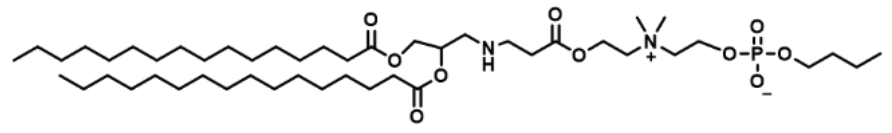

1.67809

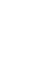

913.65992

$\mathbf{M}+\mathbf{N a}$

Mass spectra 2 
DPCP-b

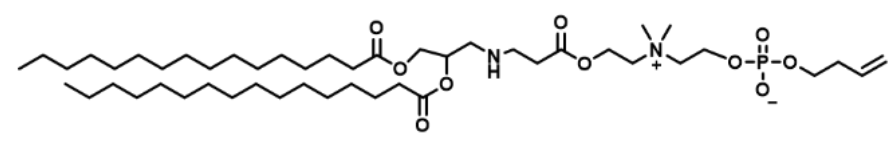

bg_wwl-3 \#9-11 RT: $0.10-0.13$ AV: 3 NL: $7.42 E 5$

T: FTMS + c ESI Full ms [100.00-1500.00]



\section{Mass spectra 3}




bg_wwl-3 \#7-12 RT: 0.08-0.15 AV: 6 NL: $6.49 E 6$

T: FTMS + c ESI Full ms [100.00-1500.00]

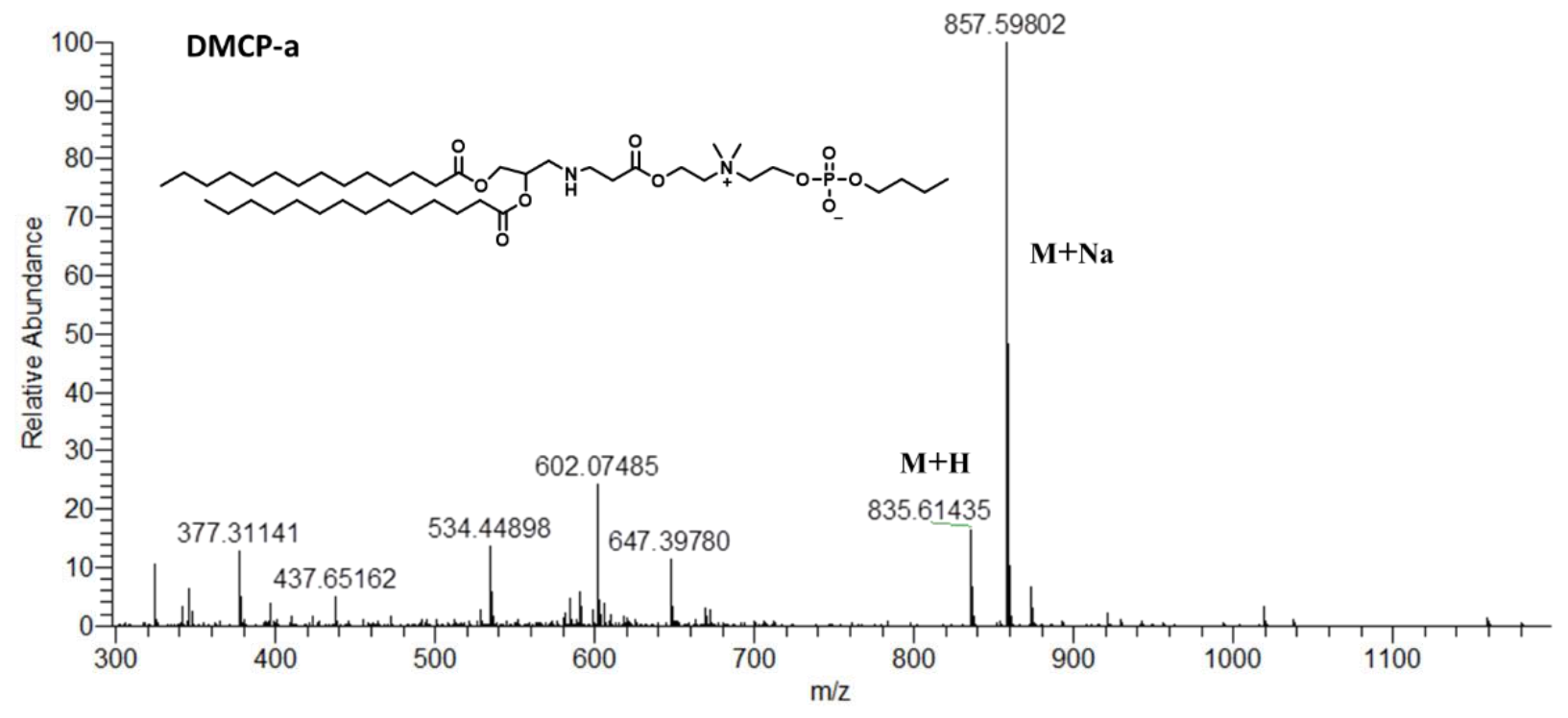

Mass spectra 5

bg_wwl-2_190816103124\#13-17 RT: 0.16-0.22 AV: 5 NL: $6.11 \mathrm{E} 6$

T: FTMS + c ESI Full ms [100.00-1500.00]



Mass spectra 6 




Mass spectra 7

20190703-9 787 (26.491) Cm (786:787-596:601)

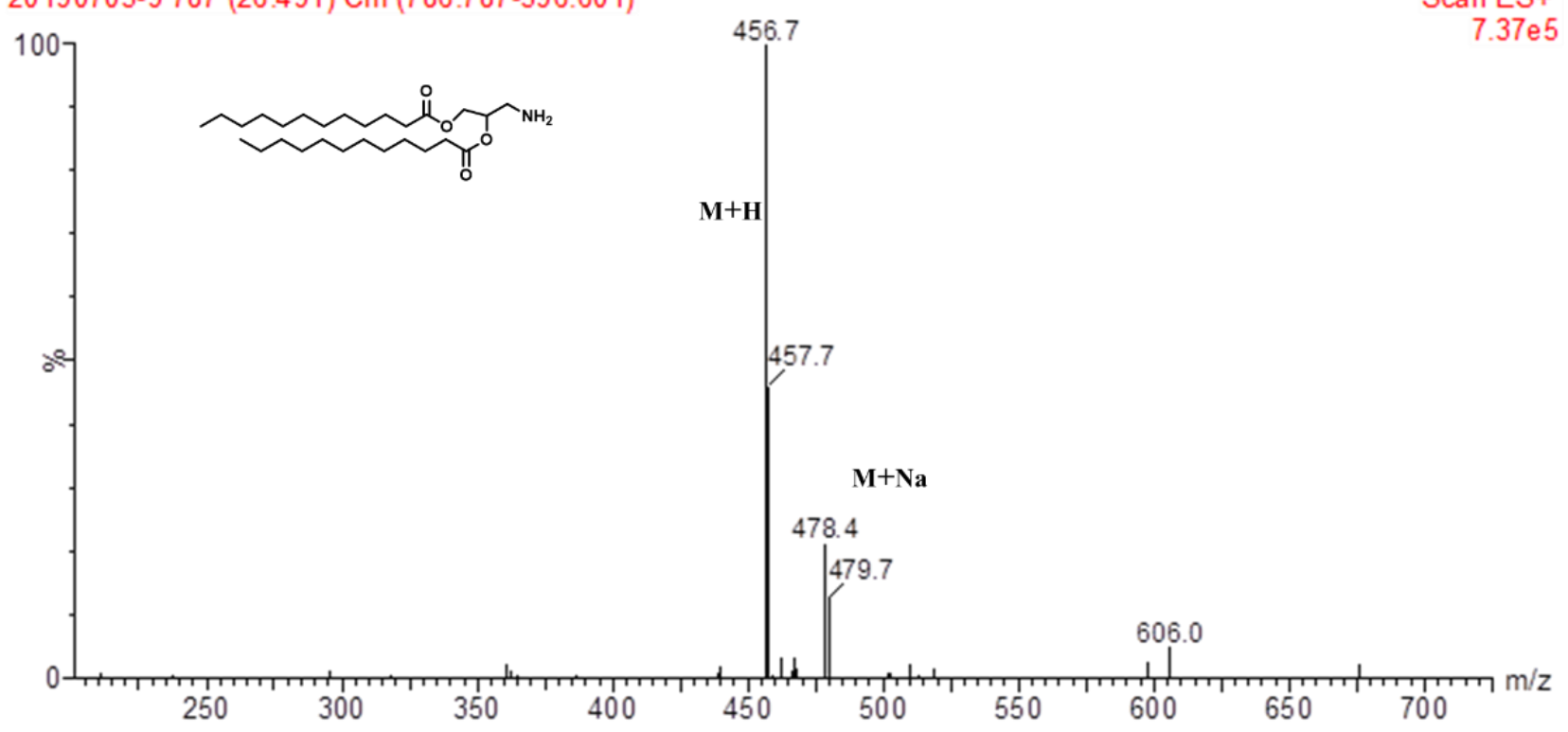

Mass spectra 8 


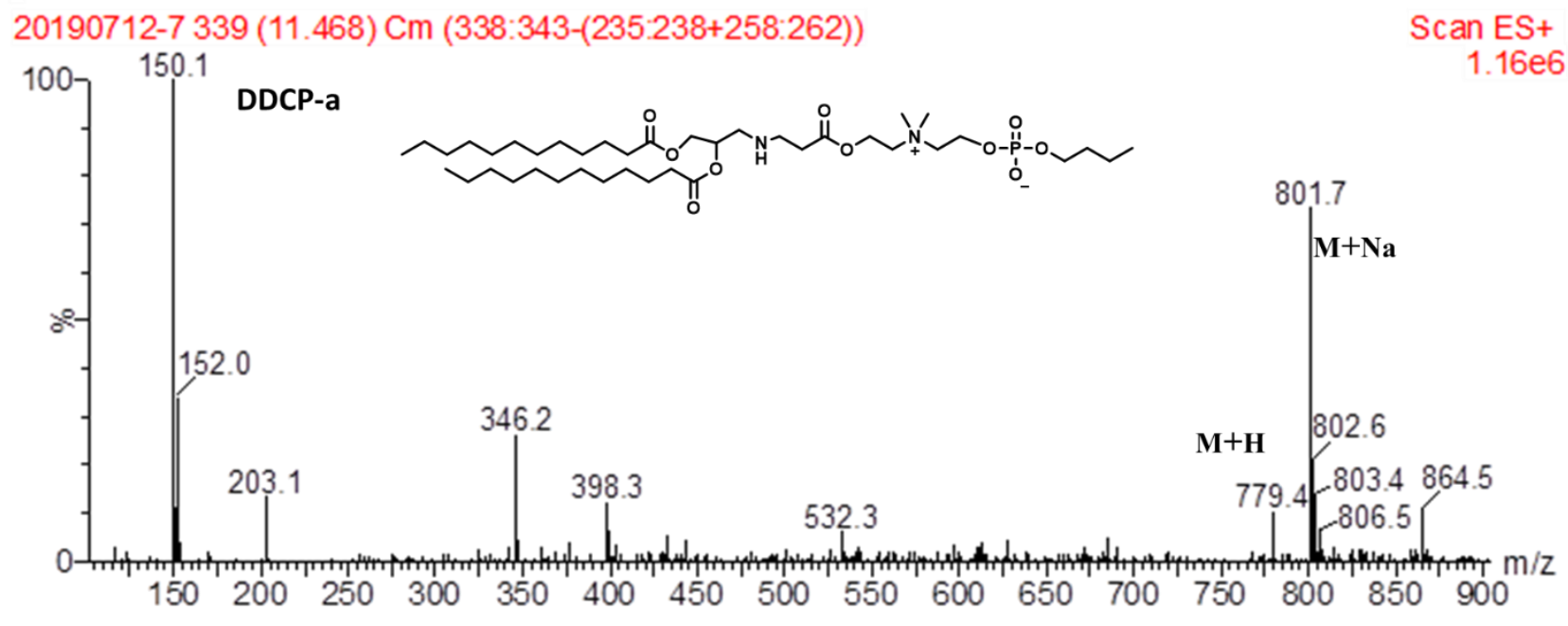

Mass spectra 9

bg_wwl-5 \#30-32 RT: 0.40-0.42 AV: 3 NL: 2.19E6

T: FTMS + c ESI Full ms [100.00-1500.00]

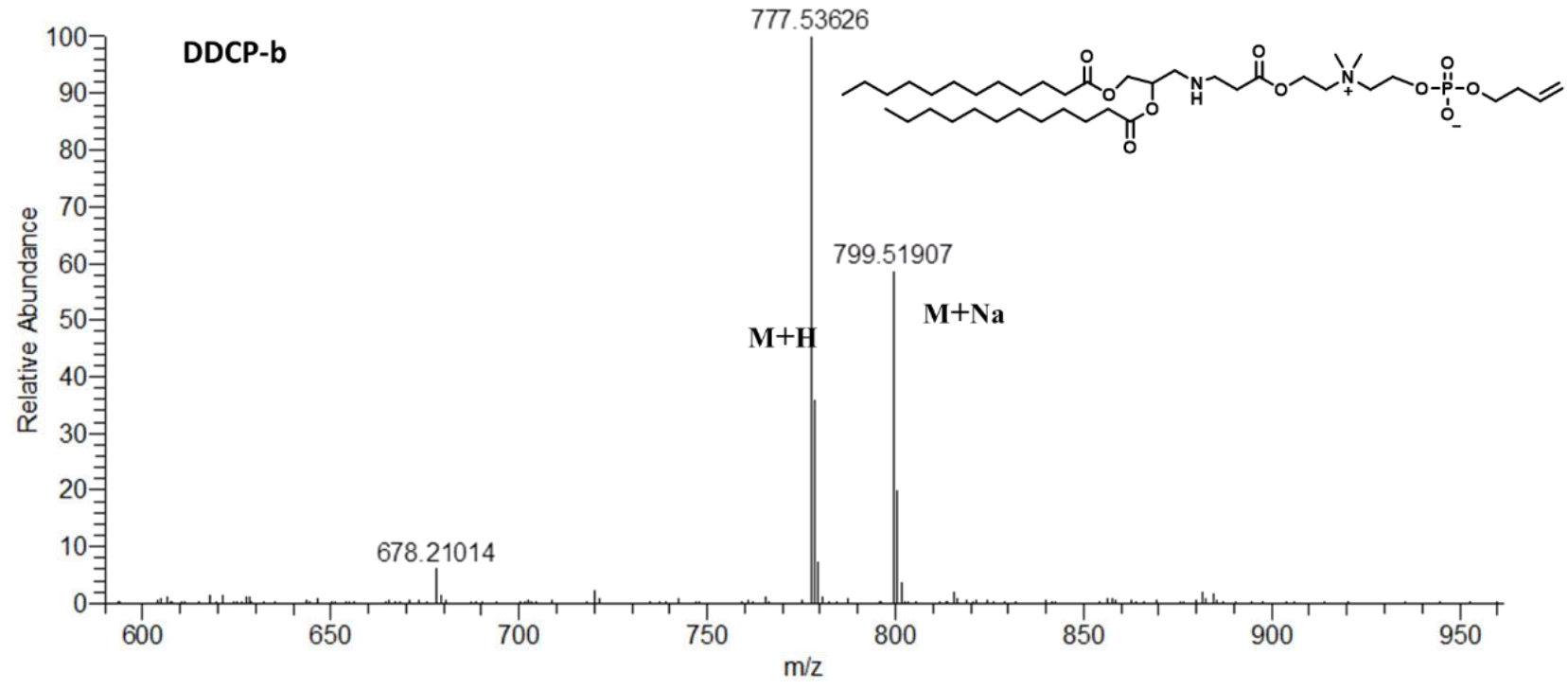

Mass spectra 10 
bg_wwl-2_190606094733\#14-18 RT: 0.17-0.23 AV: 5 NL: 1.19E7

T: FTMS + c ESI Full ms [100.00-1500.00]

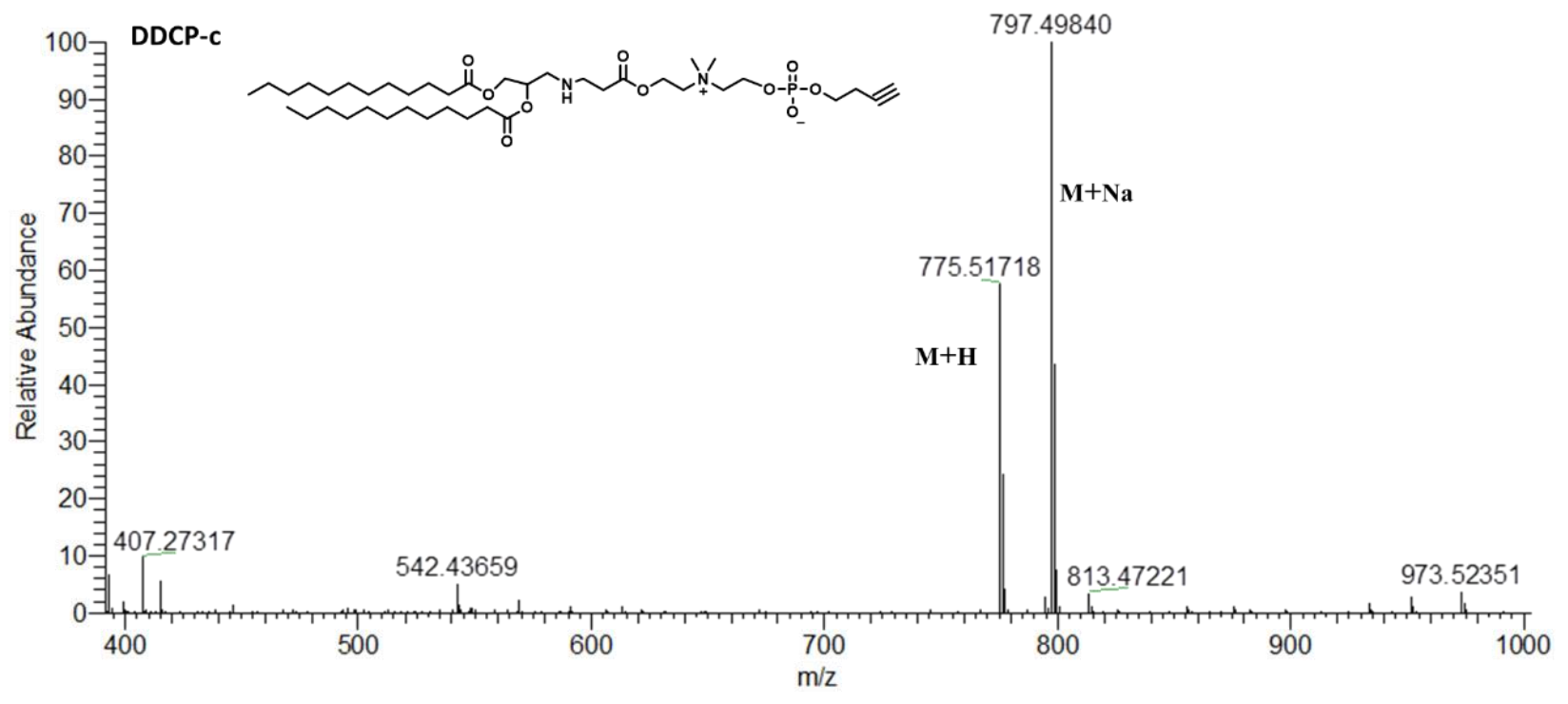

Mass spectra 11



Mass spectra 12

48 / 74 
Figures
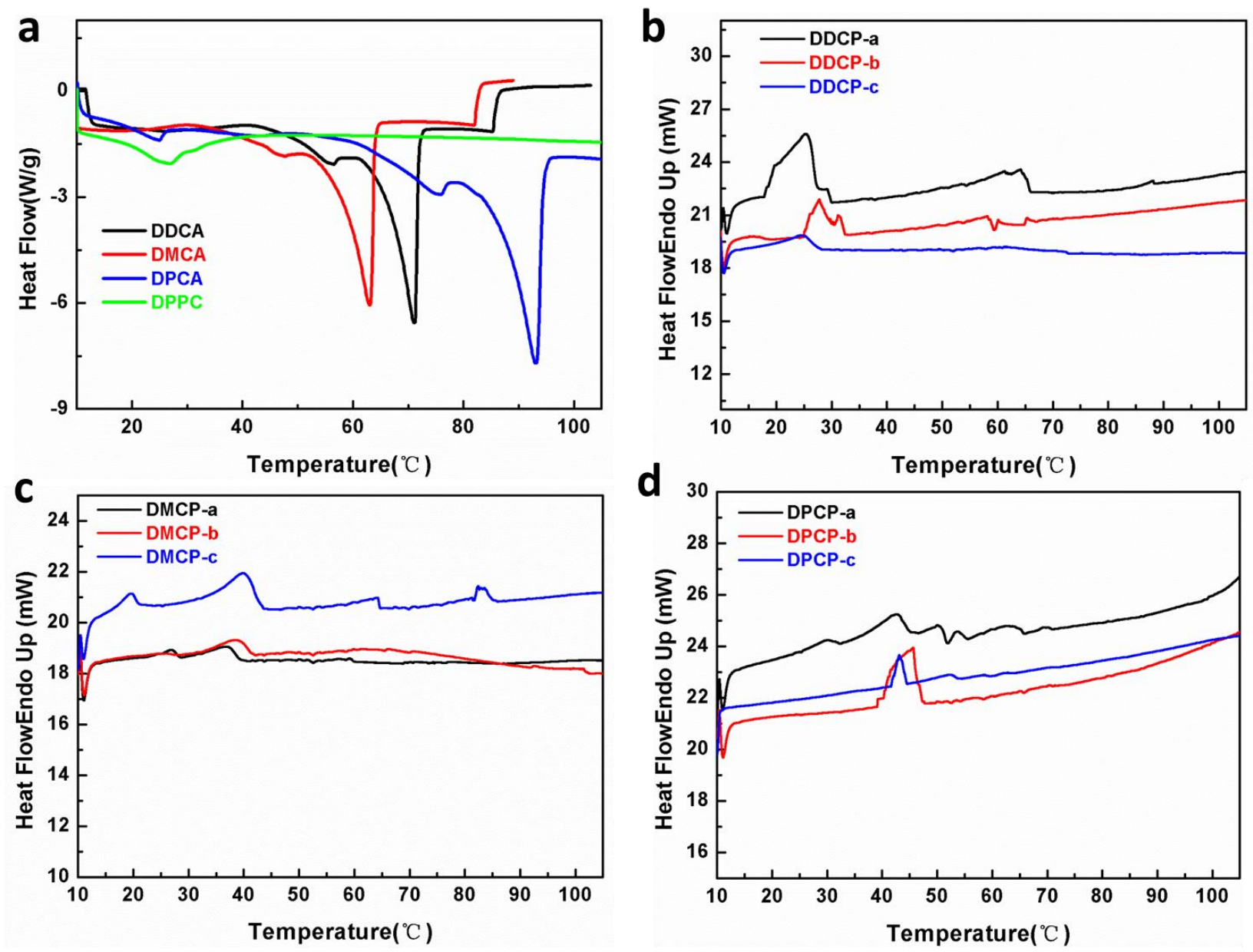

Figure S1. Representative DSC thermograms of DPPC, all kinds of CP lipids and their precursors; 




Figure S2. UV-Vis spectra of blank DPPC and all kinds of CP lipids. 


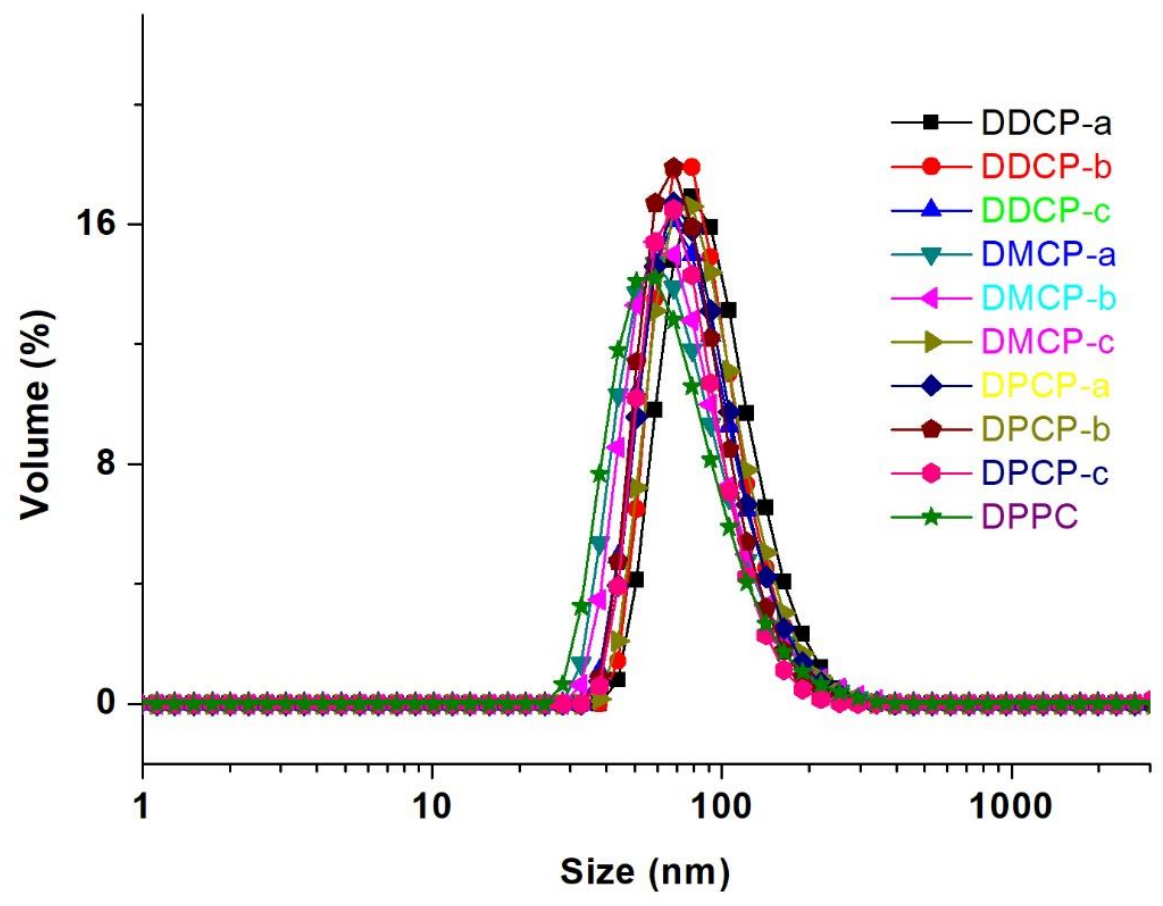

Figure S3. The DLS data of all blank PC and PC liposomes in solution 

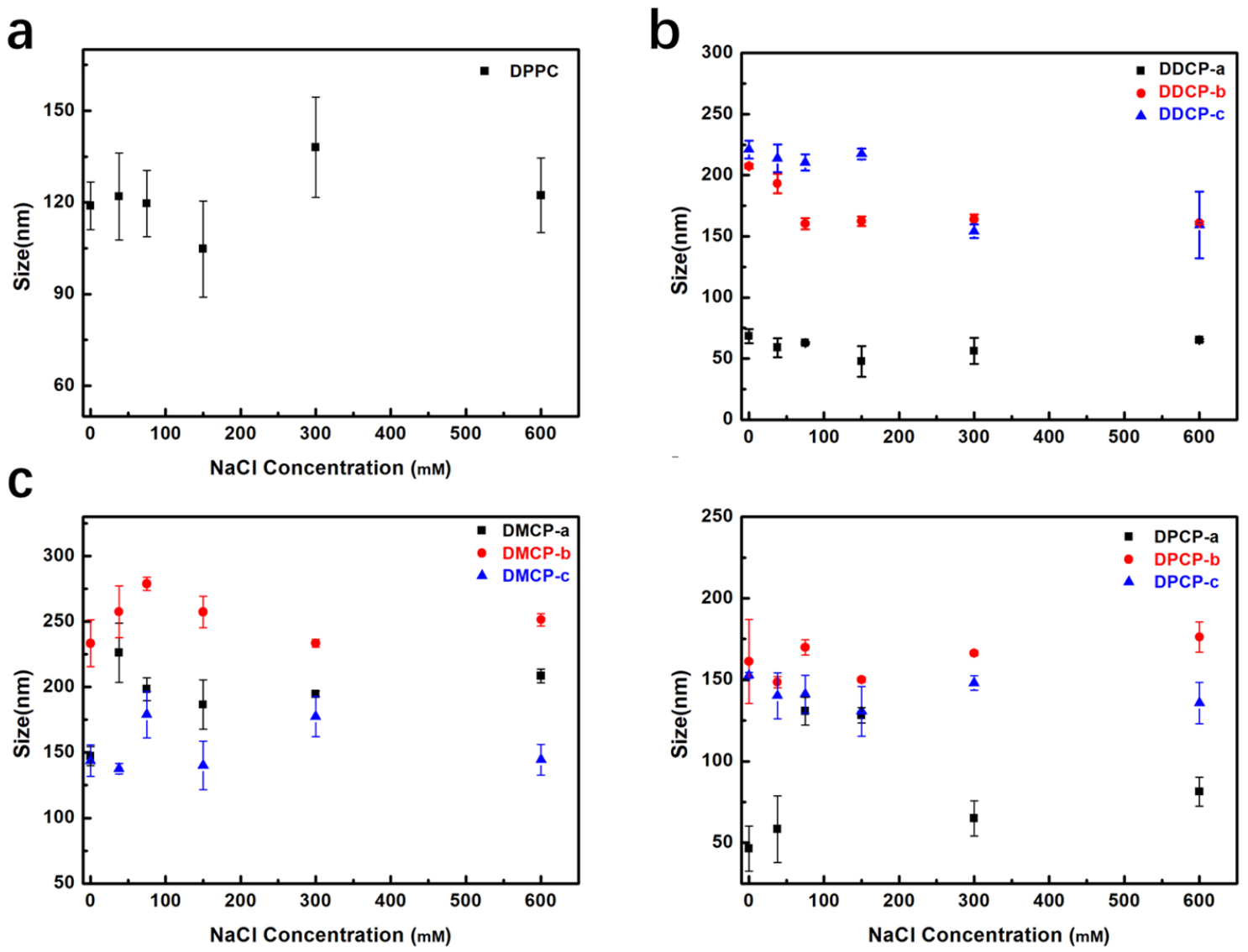

Figure S4. The diameter of nanoparticles as function of solution $\mathrm{NaCl}$ concentrations (a) DPPC, (b) DDCP, (c) DMCP and (d) DPCP 

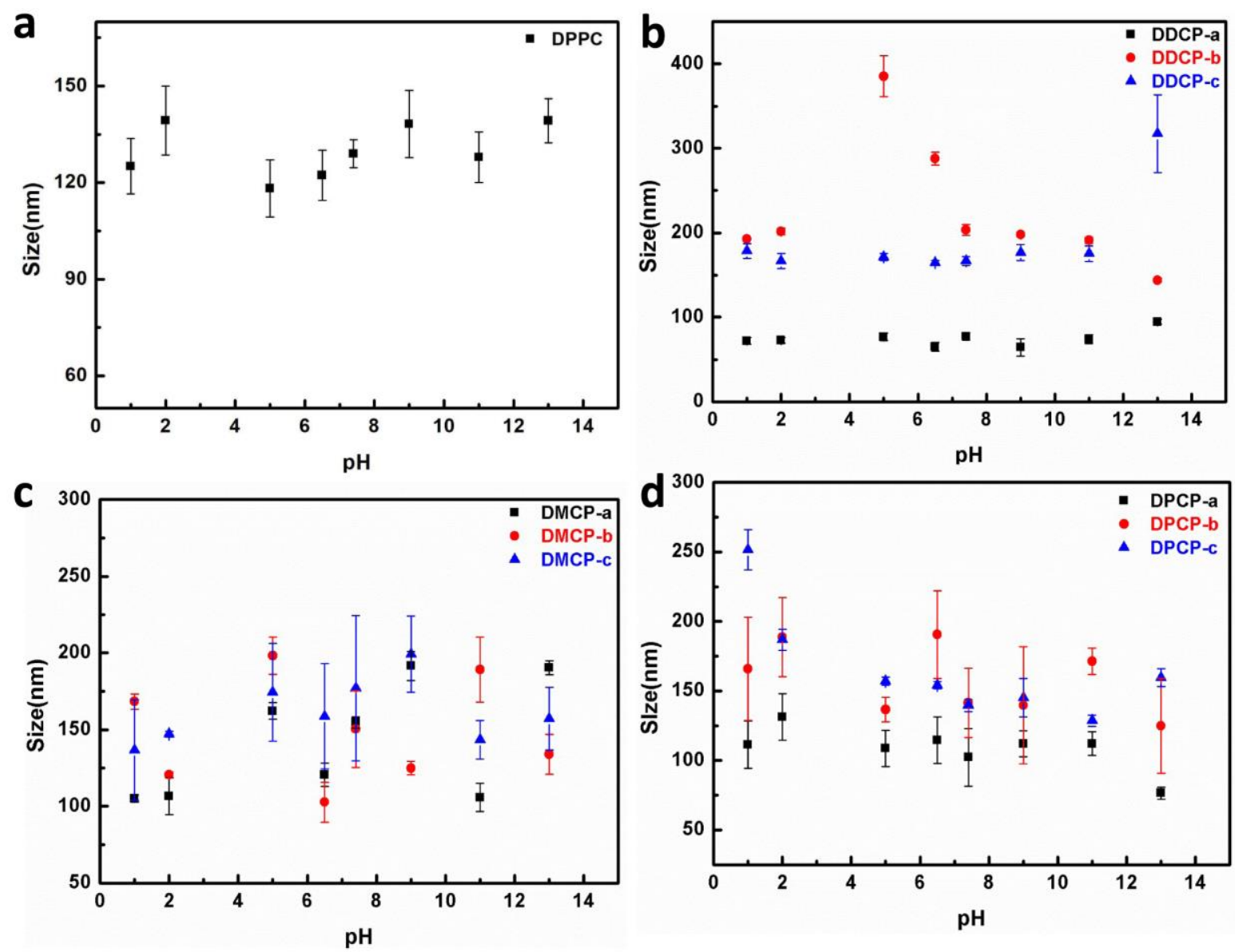

Figure S5. The diameter of nanoparticles as function of solution $\mathrm{pH}$ (a) DPPC, (b) DDCP,

(c) DMCP and (d) DPCP 

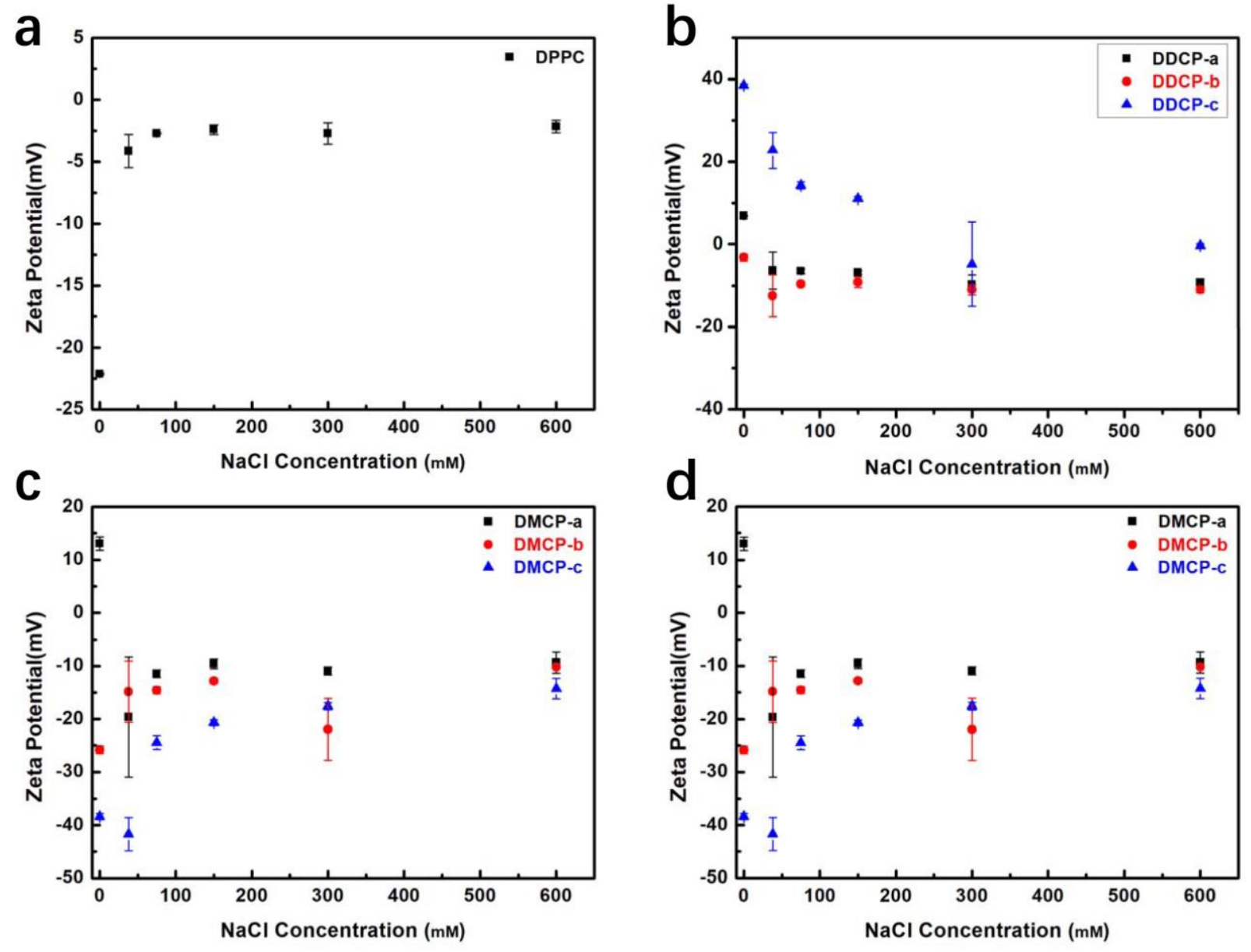

Figure S6. The zeta potential as function of solution $\mathrm{NaCl}$ concentrations (a) DPPC, (b) DDCP, (c) DMCP and (d) DPCP 

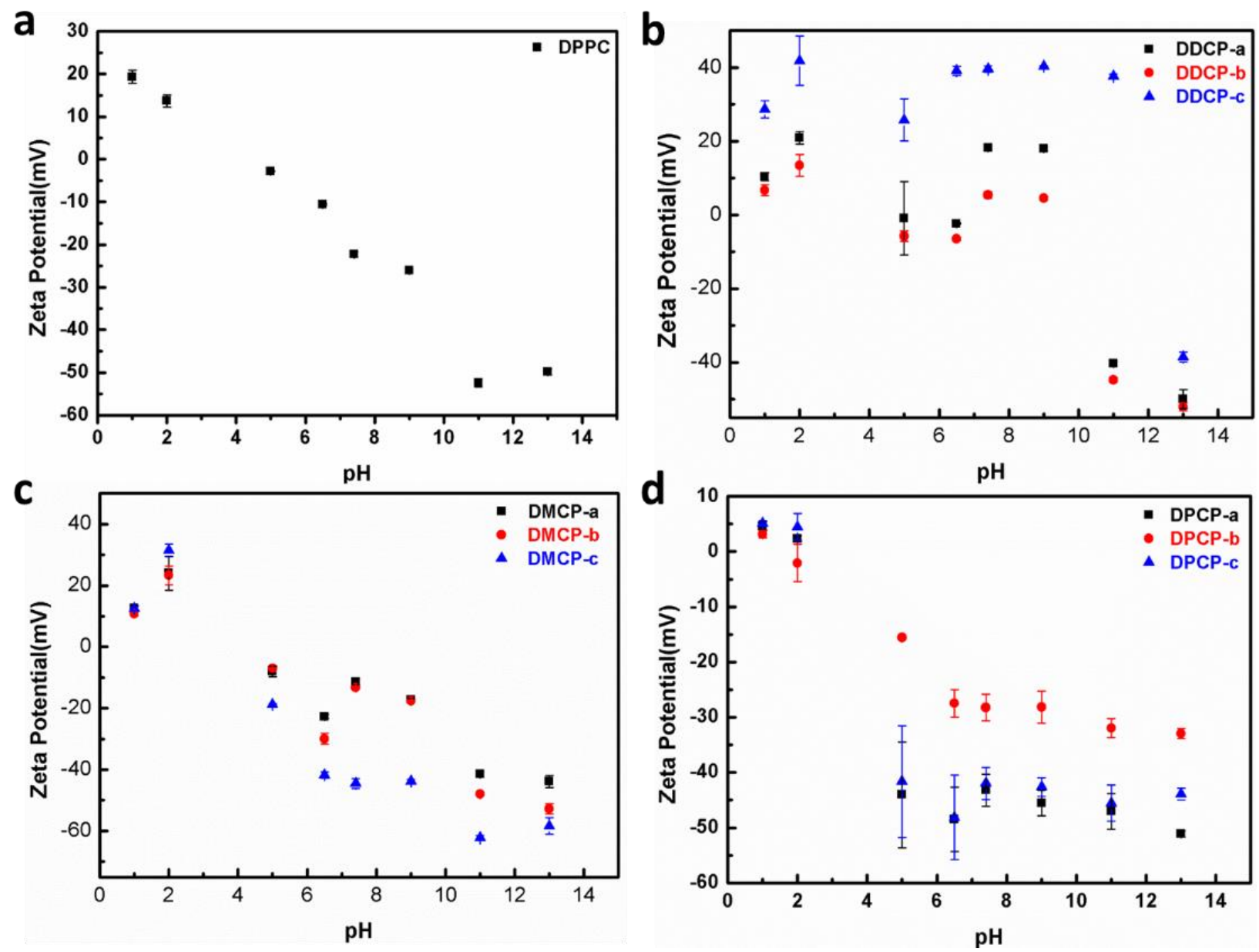

Figure S7. The zeta potential as function of solution $\mathrm{pH}$ (a) DPPC, (b) DDCP, (c) DMCP and (d) DPCP 

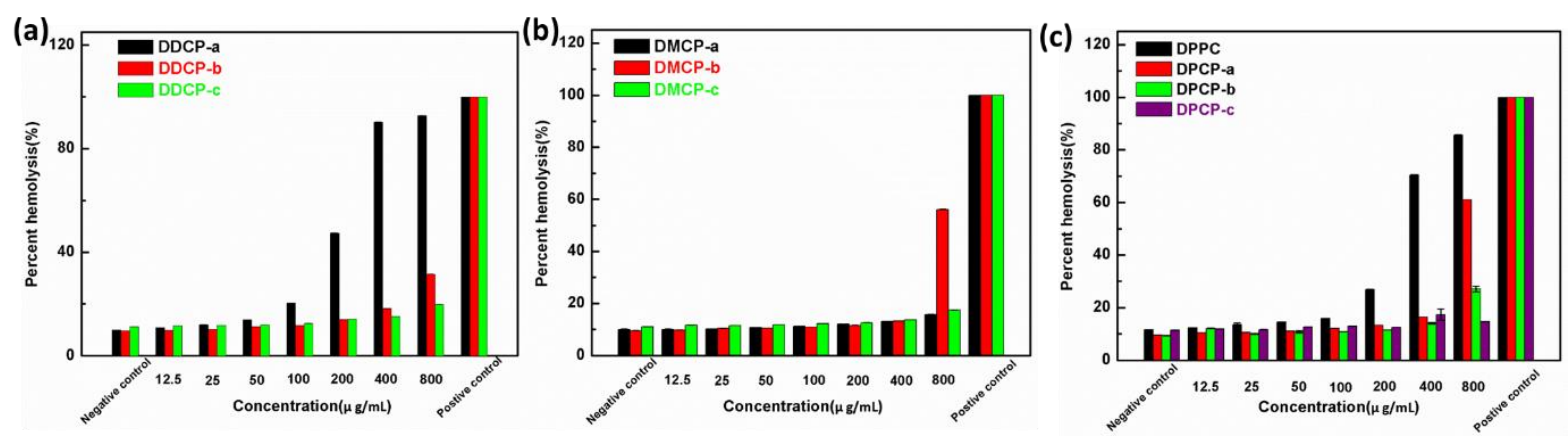

Figure S8. Hemolysis assay of CP and PC lipids with different concentrations



Figure S9. The hemolysis assay images of all kinds of CP and PC lipids. 

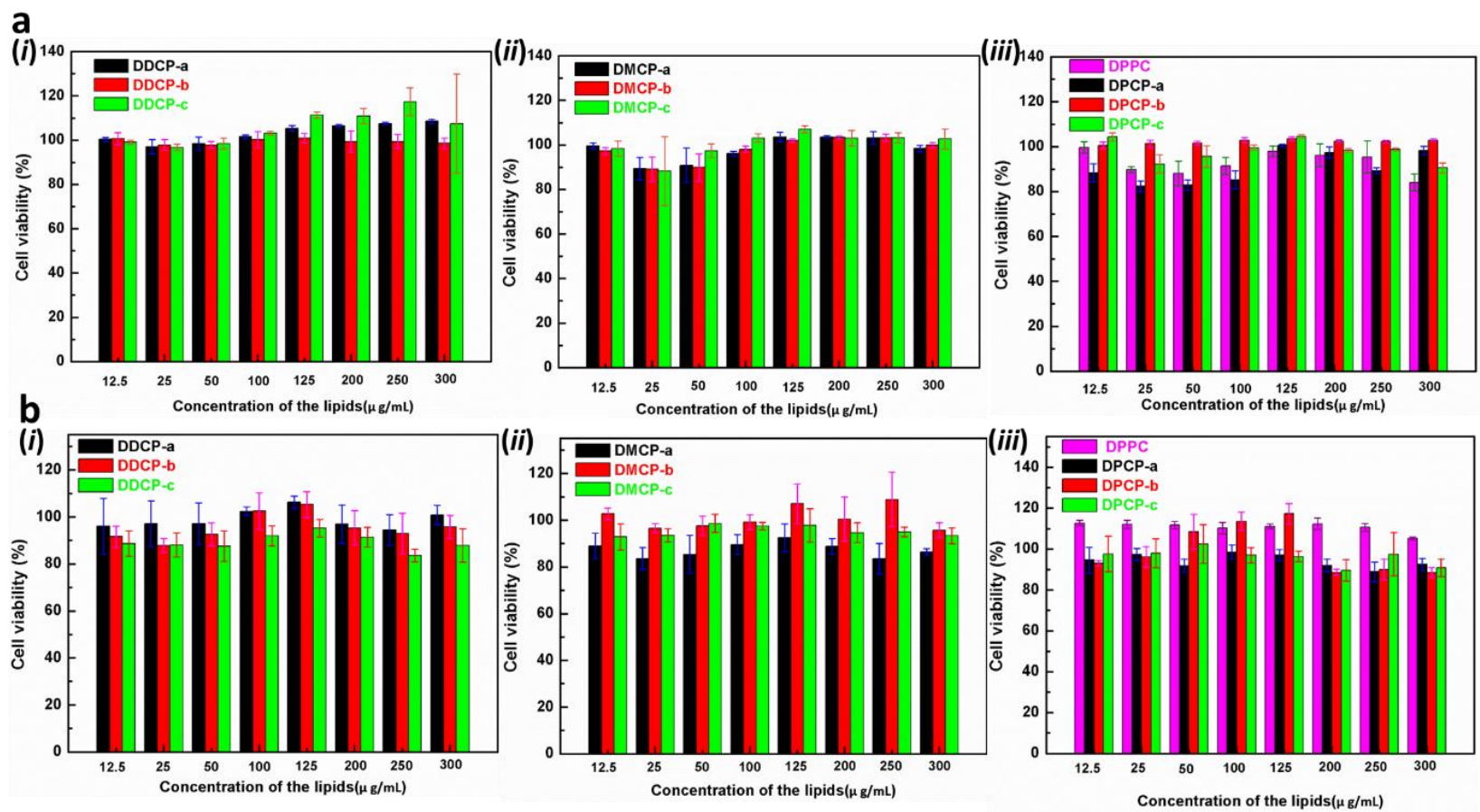

Figure S10. Cell viability of $\mathrm{CP}$ and PC lipids in NIH $3 \mathrm{~T} 3$ cells (a) and $4 \mathrm{~T} 1$ cells (b). 


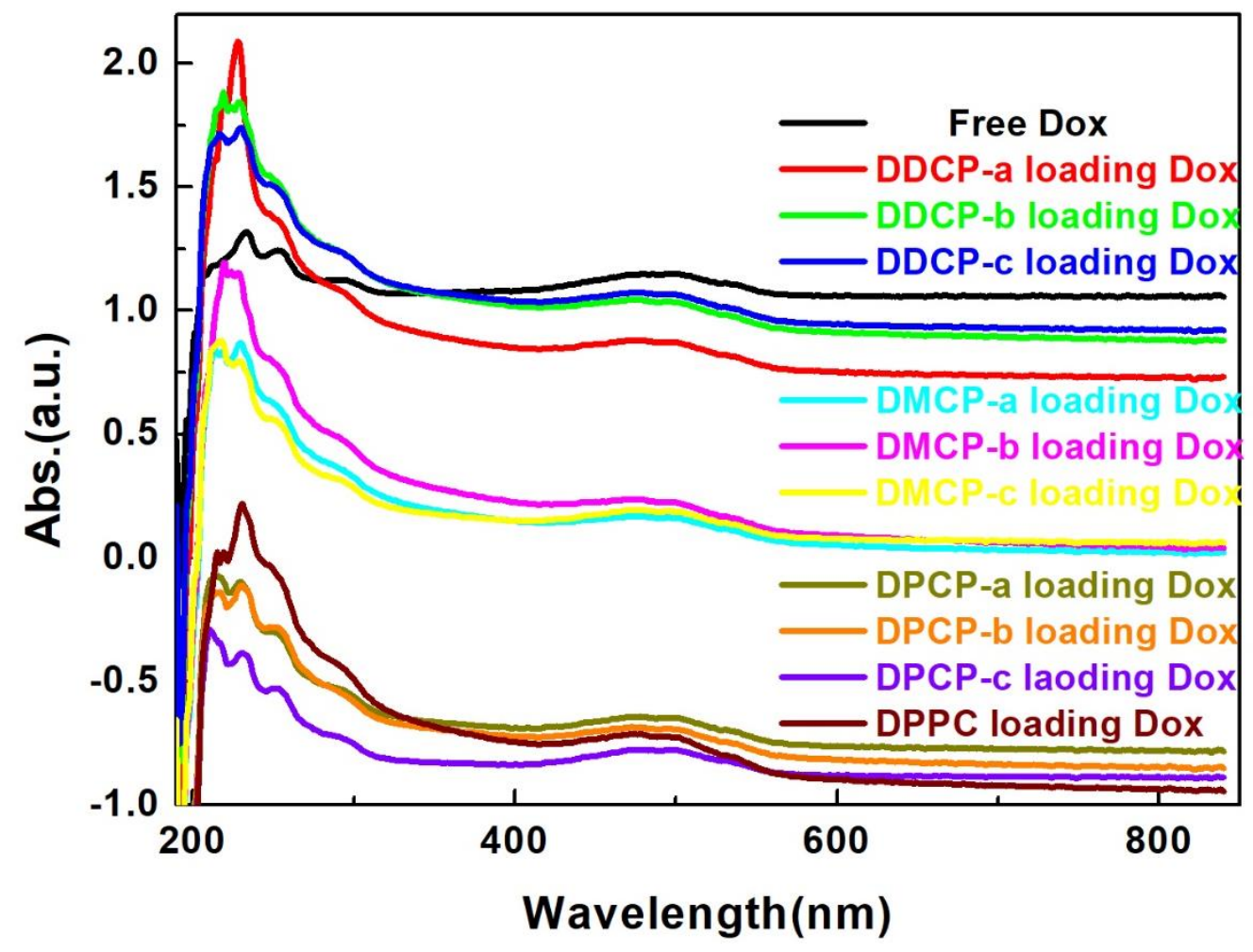

Figure S11. The UV-vis spectra of Dox-loading DPPC and CP liposomes, and free Dox in aqueous solution. 


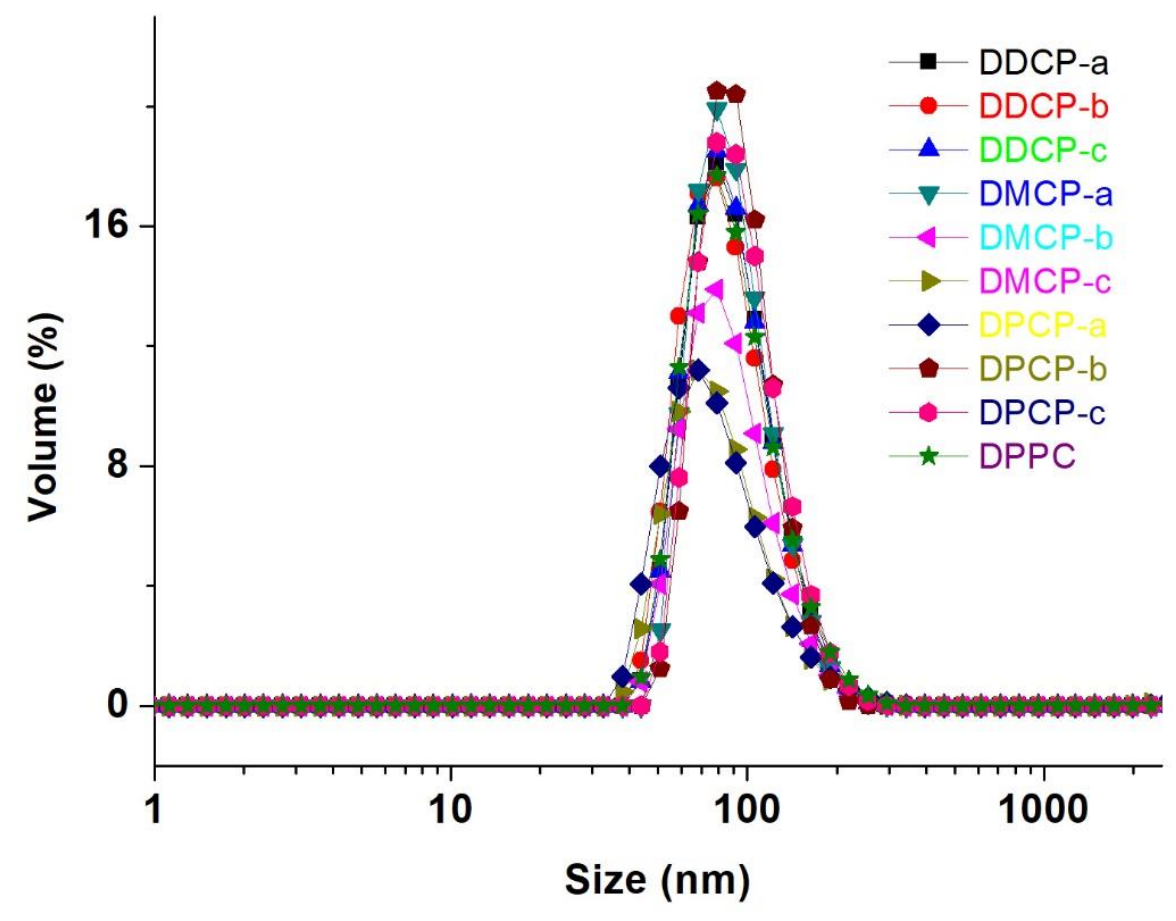

Figure S12. The DLS data of all Dox-loading PC and PC liposomes in solution 

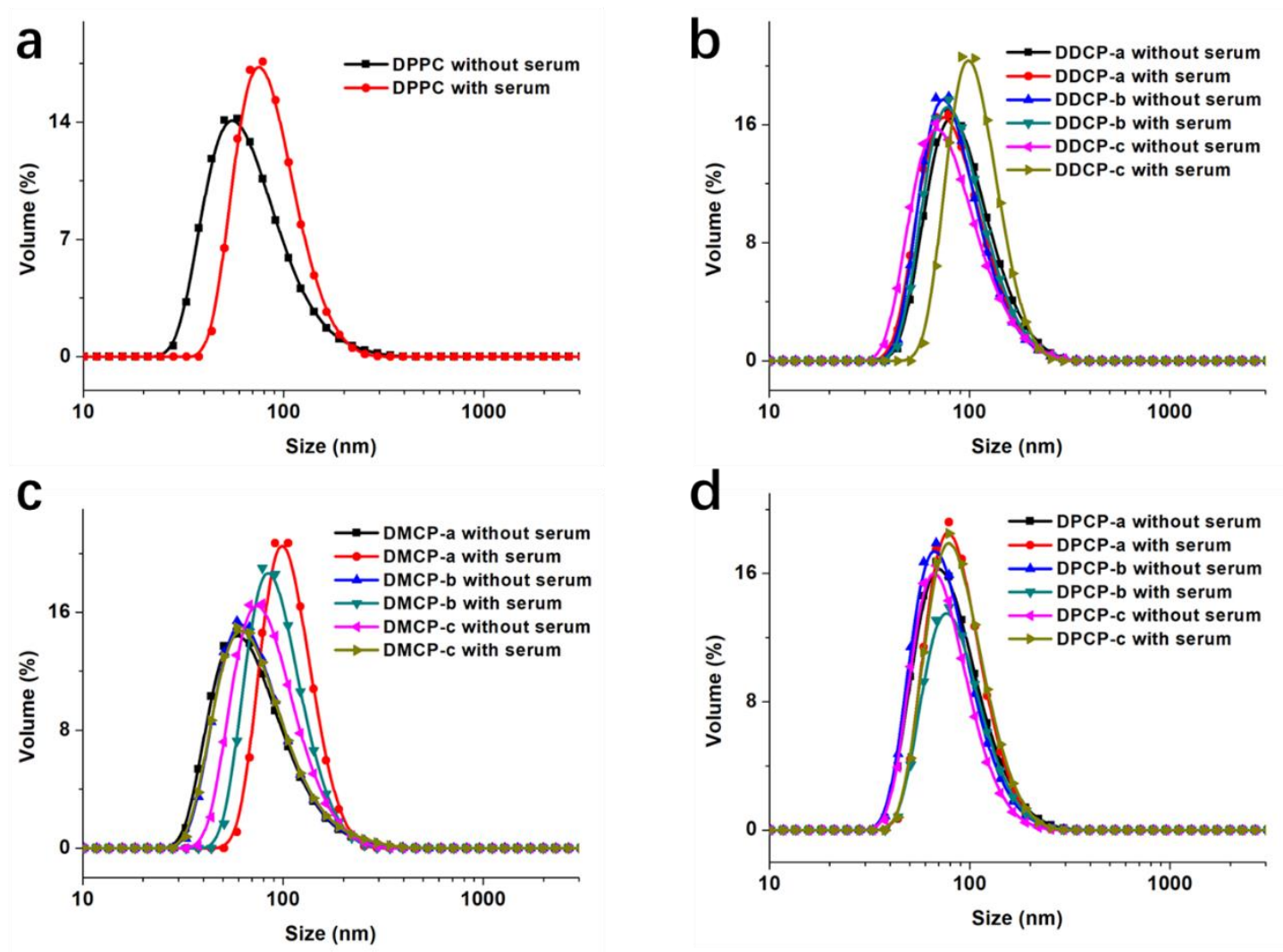

Figure S13. The size stability of CP and PC liposomes in solution with or without serum, (a) DDCP, (b) DMCP, (c) DPCP, and (d) DPPC determined via DLS. 

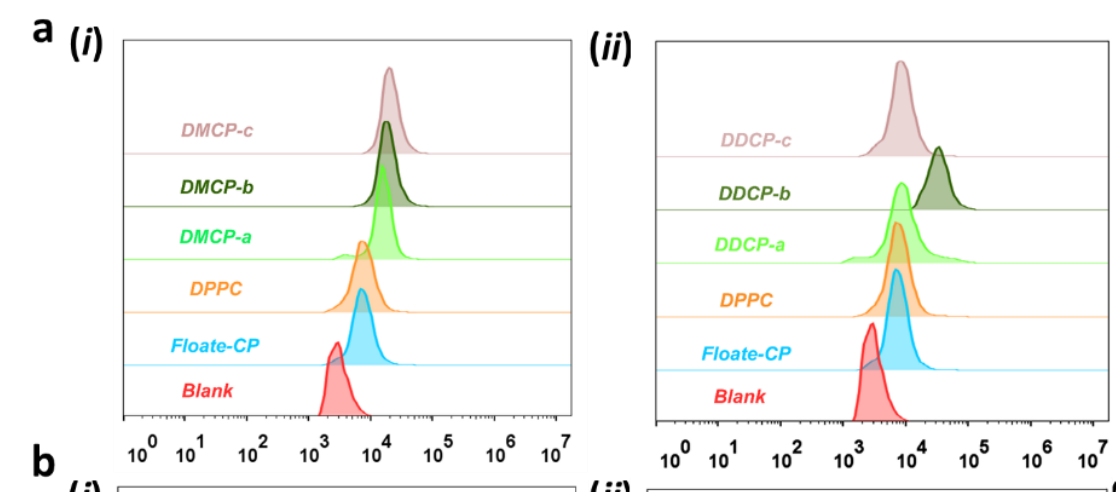

(i)

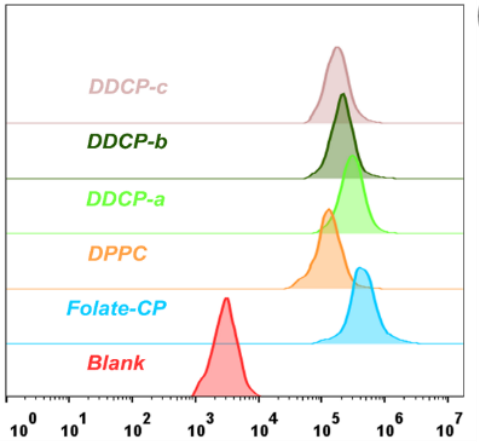

(ii)



iii)

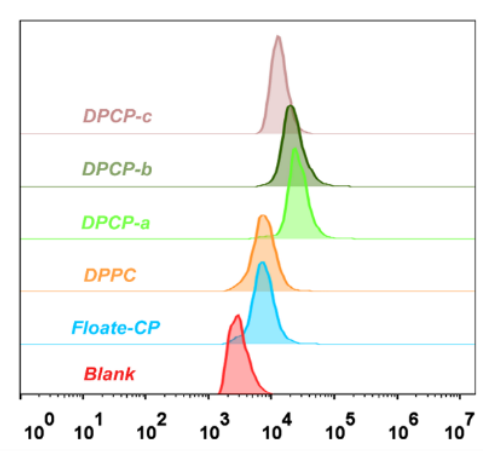

(iii)

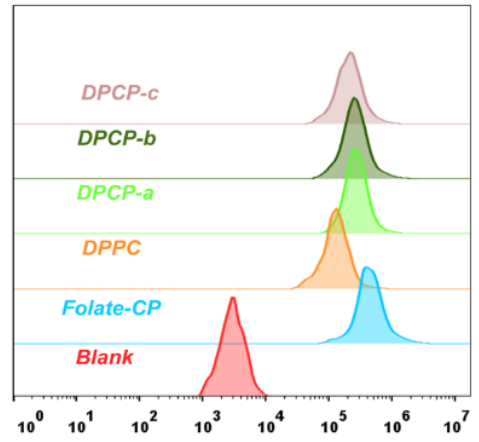

Figure S14. Flow cytometry analysis of NIH 3T3 cells (a) and 4T1 cells (b) after treated via Dox-loaded CP and PC liposomes with Dox concentration $10 \mu \mathrm{g} / \mathrm{mL}$, respectively for 1 $\mathrm{h}$; 
(a)

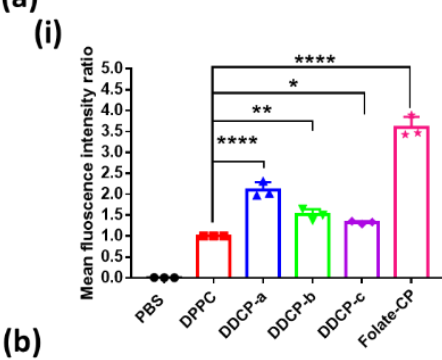

(i)



(ii)

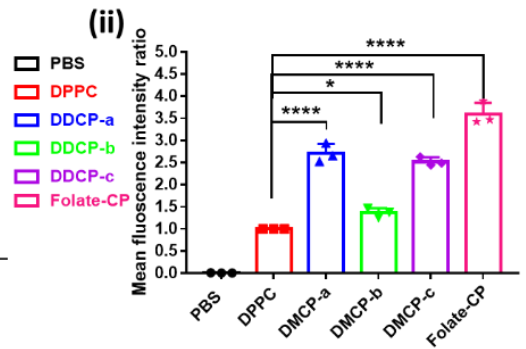

(ii)

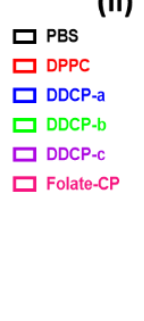

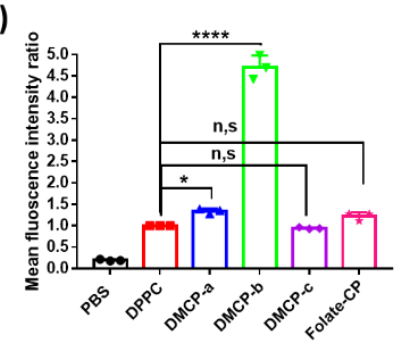

(iii)。

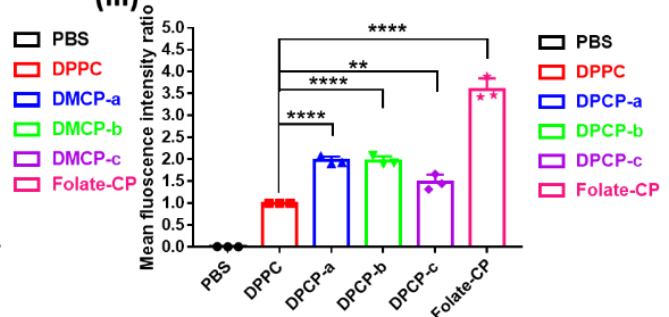

(iii)

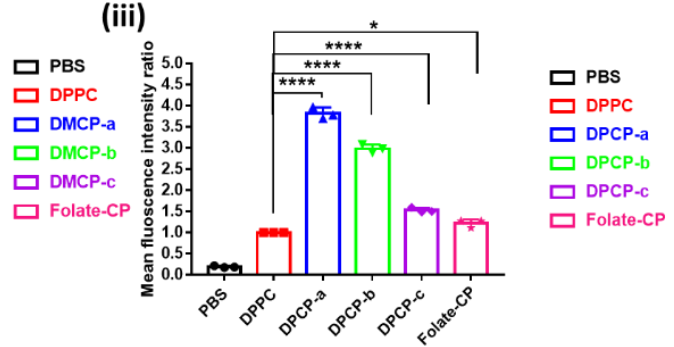

Figure S15. Mean fluorescence intensity (MFI) ratio analysis of $4 \mathrm{~T} 1$ cells (a) and $\mathrm{NIH}$ ЗТ3 (b) after treated via Dox-loaded CP and PC liposomes with Dox concentration10 $\mu \mathrm{g} / \mathrm{mL}$ (i) DDCP, (ii) DCP, and (iii) DPCP. 




Figure S16. CLSM images of NIH 3T3 cells after treated via Dox-loaded CP and PC liposomes with Dox concentration $10 \mu \mathrm{g} / \mathrm{mL}$ (scale bar: $20 \mu \mathrm{m}$ ); 


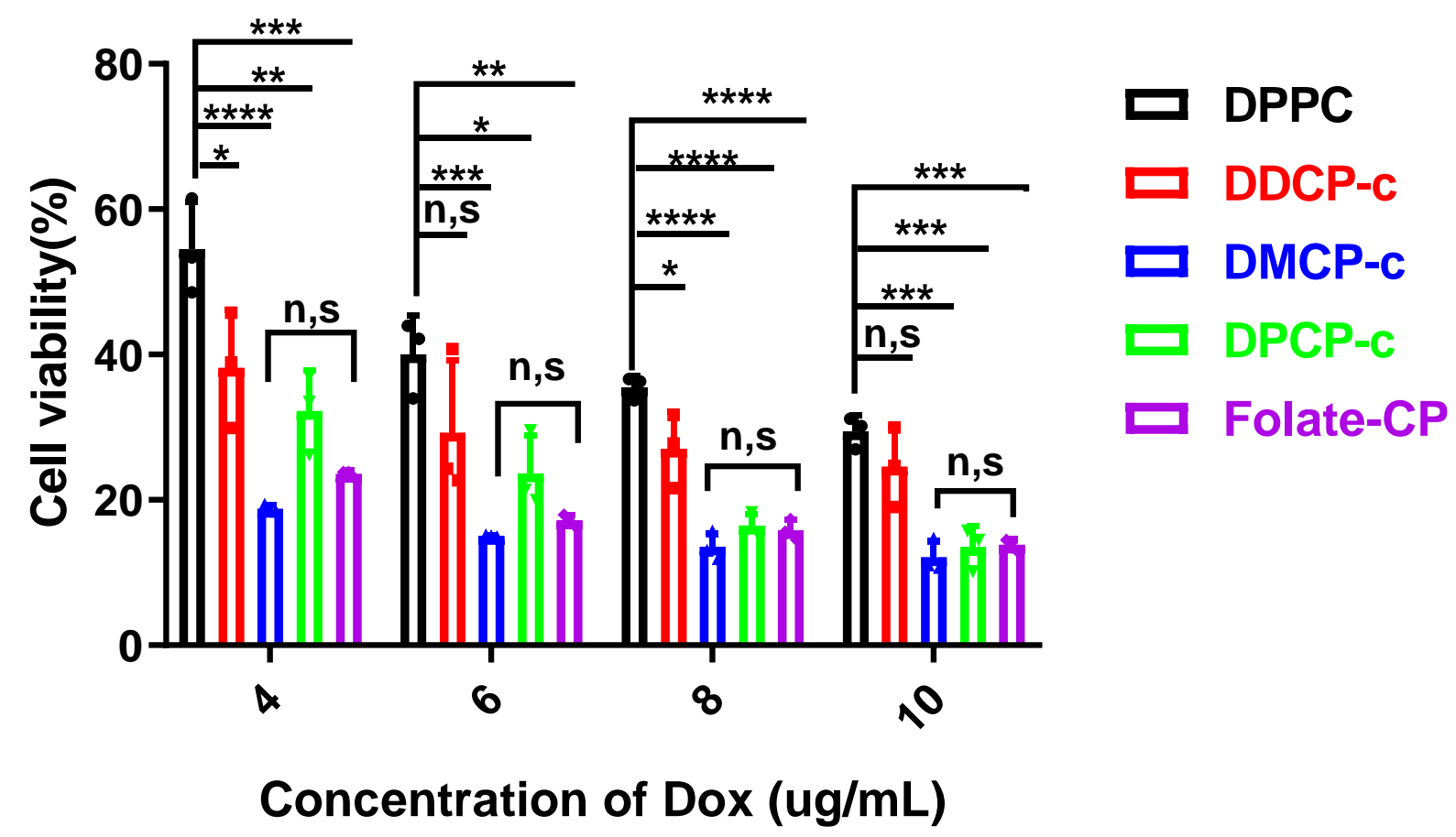

Figure S17. The cell viability in NIH 3T3 cells after incubated via Dox-loaded CP and PC liposomes with different Dox concentration for $24 \mathrm{~h}$. 


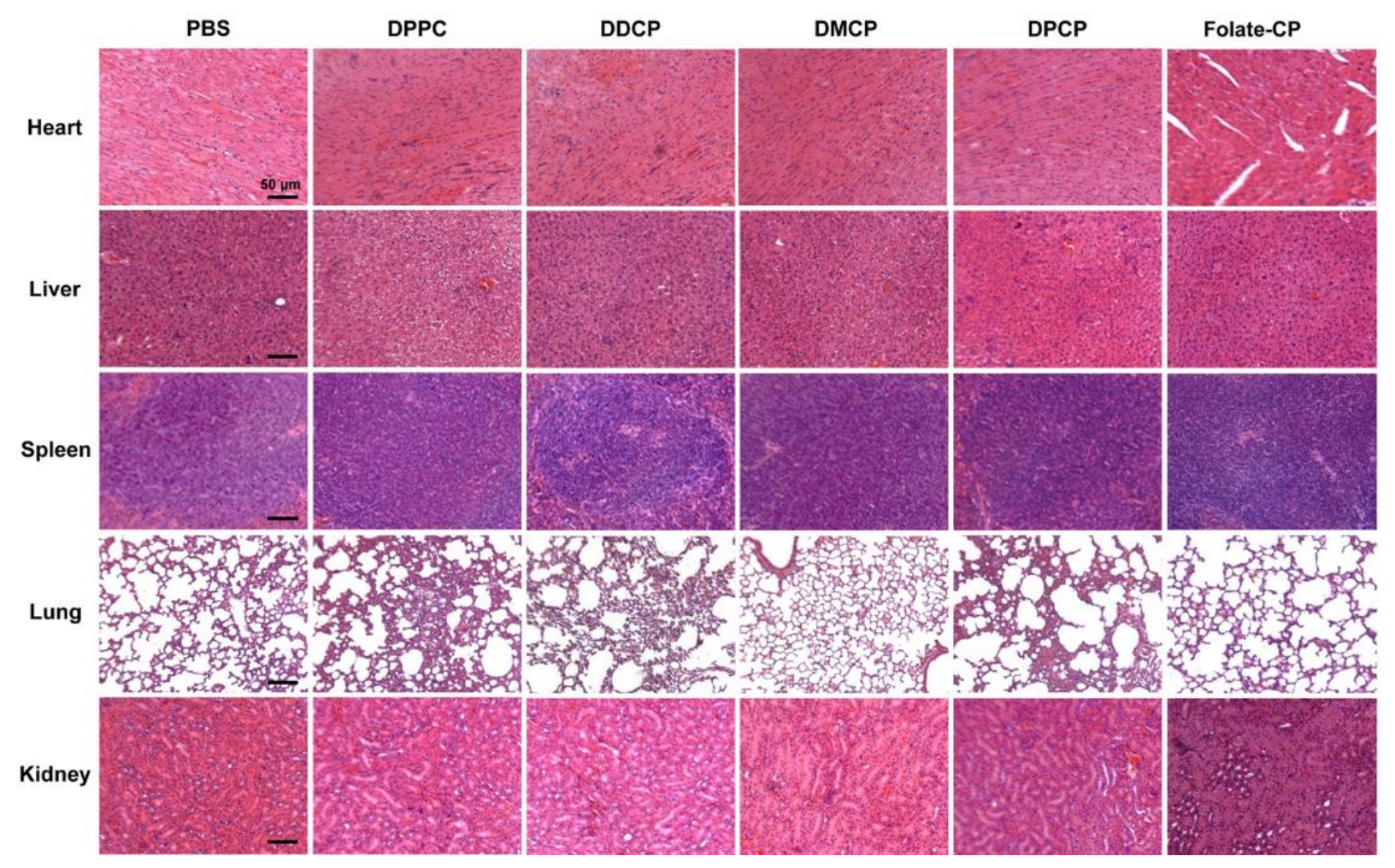

Figure S18. Hematoxylin and eosin (H\&E) analysis of normal tissues (including heart, liver, spleen, lung, kidney) after treated via Dox-loaded CP and PC liposomes. 


\section{Tables}

Table S1. The yield of all kinds of CP lipids.

\begin{tabular}{ccc}
\hline entries & Chemicals & Yield (\%) \\
\hline $\mathbf{1}$ & DDCP-a & 31.4 \\
\hline $\mathbf{3}$ & DDCP-b & 32.7 \\
$\mathbf{4}$ & DDCP-C & 26.7 \\
$\mathbf{5}$ & DMCP-a & 21.4 \\
$\mathbf{6}$ & DMCP-b & 20.3 \\
\hline $\mathbf{7}$ & DMCP-c & 23.6 \\
\hline $\mathbf{8}$ & DPCP-a & 10.8 \\
\hline $\mathbf{9}$ & DPCP-b & 11.6 \\
\hline
\end{tabular}


Table S2. The Tm of all kinds of CP, PC lipids and their precursors.

\begin{tabular}{|c|c|c|}
\hline entries & Chemicals & Tm (Peak, $\left.{ }^{\circ} \mathrm{C}\right)$ \\
\hline 1 & DDCA & 83.2 \\
\hline 2 & DDCP-a & 25.7 \\
\hline 3 & DDCP-b & 26.4 \\
\hline 4 & DDCP-C & 25.0 \\
\hline 5 & DMCA & 94.9 \\
\hline 6 & DMCP-a & 36.9 \\
\hline 7 & DMCP-b & 38.5 \\
\hline 8 & DMCP-c & 39.9 \\
\hline 9 & DPPC & 27.3 \\
\hline 10 & DPCA & 93.7 \\
\hline 11 & DPCP-a & 42.6 \\
\hline 12 & DPCP-b & 45.3 \\
\hline 13 & DPCP-c & 51.8 \\
\hline
\end{tabular}


Table S3. The size distribution of liposomes before (a) and after (b) loading Dox determined via DLS.

\begin{tabular}{cccccc}
\hline entries & Chemicals & Size $^{\mathbf{a}}$ & PDI & Size $^{\mathbf{b}}$ & PDI \\
\hline $\mathbf{1}$ & DDCP-a & $140.3 \pm 13.3$ & 0.118 & $143.0 \pm 12.4$ & 0.209 \\
\hline $\mathbf{2}$ & DDCP-b & $137.3 \pm 23.1$ & 0.201 & $123.0 \pm 20.6$ & 0.311 \\
$\mathbf{3}$ & DDCP-c & $138.0 \pm 27.2$ & 0.278 & $125.3 \pm 11.8$ & 0.247 \\
$\mathbf{4}$ & DMCP-a & $132.6 \pm 17.9$ & 0.145 & $135.0 \pm 6.0$ & 0.145 \\
$\mathbf{5}$ & DMCP-b & $150.6 \pm 24.6$ & 0.117 & $154.0 \pm 9.1$ & 0.179 \\
\hline $\mathbf{6}$ & DMCP-c & $143.6 \pm 14.7$ & 0.232 & $149.0 \pm 14.9$ & 0.216 \\
\hline $\mathbf{7}$ & DPCP-a & $143.0 \pm 24.5$ & 0.168 & $139.0 \pm 15.6$ & 0.118 \\
\hline $\mathbf{8}$ & DPCP-b & $124.0 \pm 14.0$ & 0.179 & $128.6 \pm 20.4$ & 0.169 \\
\hline $\mathbf{9}$ & DPCP-c & $151.3 \pm 16.2$ & 0.224 & $154.0 \pm 16.5$ & 0.155 \\
\hline & DPPC & $105.0 \pm 10.8$ & 0.251 & $106.3 \pm 13.0$ & 0.186 \\
\hline
\end{tabular}


Table S4. The serum biochemical analysis of CP lipids in vivo.

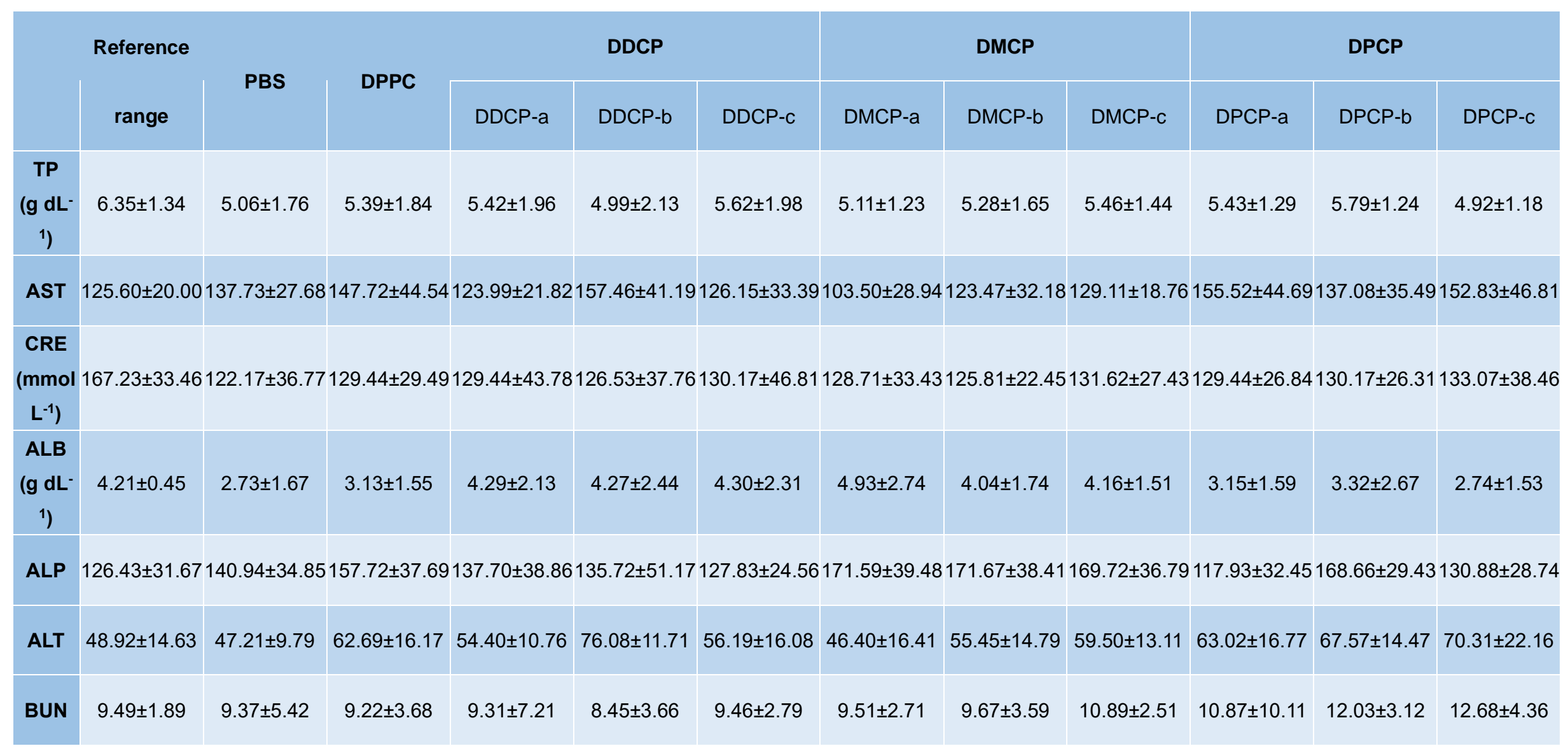


Table S5. The hematology analysis of CP lipids in vivo.

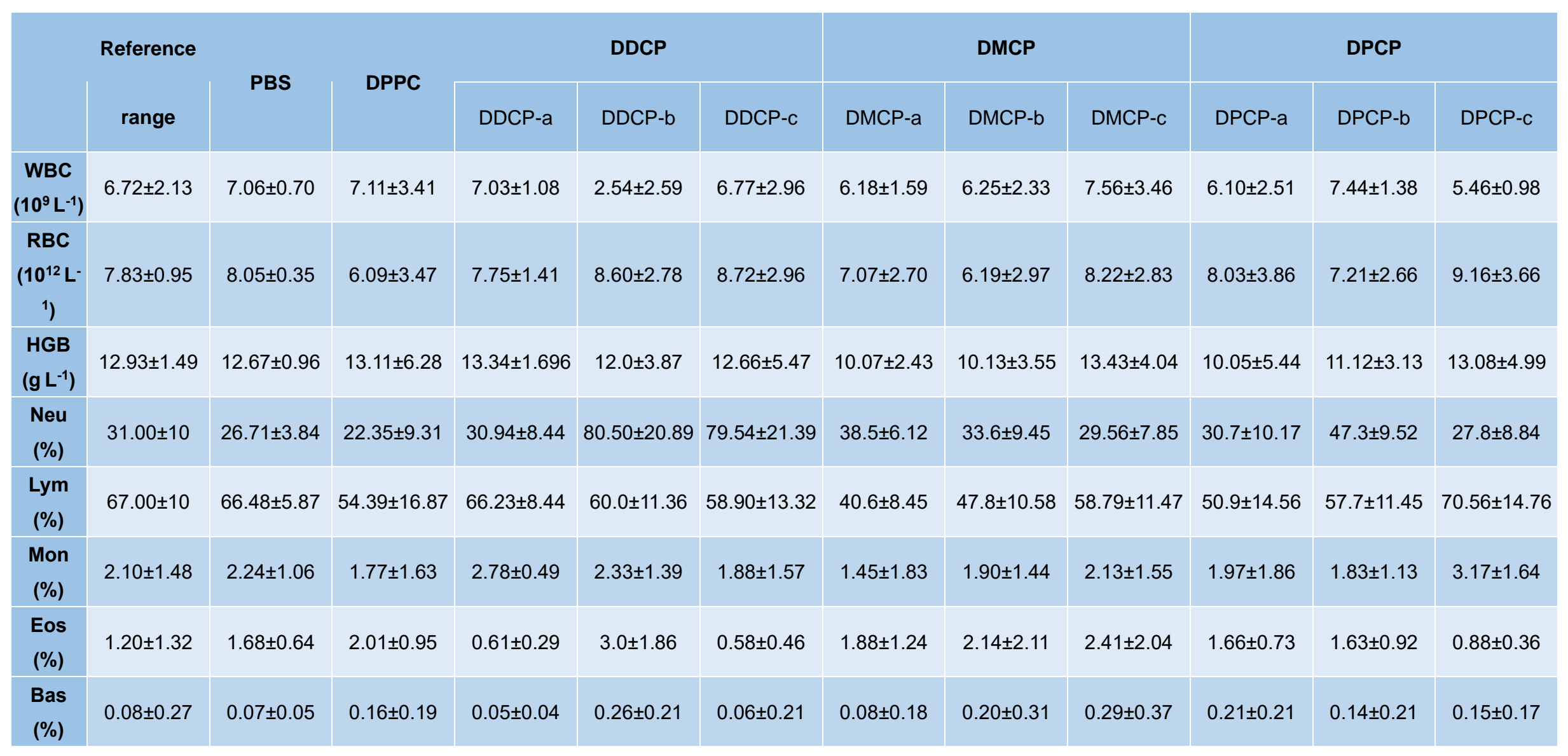


Table S6. The DLC and DLE of CP and PC liposomes.

\begin{tabular}{cccc}
\hline entries & Chemicals & DLE (\%) & DLC (\%) \\
\hline $\mathbf{1}$ & DDCP-a & $65.3 \pm 11.4$ & $2.88 \pm 0.49$ \\
\hline $\mathbf{2}$ & DDCP-b & $62.0 \pm 2.9$ & $5.33 \pm 0.23$ \\
\hline $\mathbf{4}$ & DDCP-c & $66.7 \pm 2.7$ & $5.72 \pm 0.22$ \\
\hline $\mathbf{5}$ & DMCP-a & $70.7 \pm 5.8$ & $6.04 \pm 0.47$ \\
\hline $\mathbf{6}$ & DMCP-b & $70.5 \pm 8.9$ & $5.20 \pm 0.63$ \\
\hline $\mathbf{7}$ & DMCP-c & $80.5 \pm 4.8$ & $5.53 \pm 0.31$ \\
\hline $\mathbf{9}$ & DPCP-a & $80.3 \pm 1.4$ & $6.80 \pm 0.11$ \\
\hline $\mathbf{1 0}$ & DPCP-b & $61.1 \pm 9.3$ & $3.91 \pm 0.57$ \\
\hline
\end{tabular}


Table S7. The mean fluorescence intensity ratio in 4T1 cells after treated for $1 \mathrm{~h}$ via Dox-loaded liposomes.

\begin{tabular}{|c|c|c|}
\hline entries & group & MFI ratio \\
\hline 1 & PBS & $0.0089 \pm 0.0025$ \\
\hline 2 & DPPC & 1 \\
\hline 3 & DDCP-a & $2.11 \pm 0.18$ \\
\hline 4 & DDCP-b & $1.51 \pm 0.14$ \\
\hline 5 & DDCP-C & $1.33 \pm 0.03$ \\
\hline 6 & DMCP-a & $2.71 \pm 0.21$ \\
\hline 7 & DMCP-b & $1.37 \pm 0.10$ \\
\hline 8 & DMCP-c & $2.52 \pm 0.10$ \\
\hline 9 & DPCP-a & $1.97 \pm 0.09$ \\
\hline 10 & DPCP-b & $1.97 \pm 0.11$ \\
\hline 11 & DPCP-c & $1.48 \pm 0.17$ \\
\hline 12 & Folate-CP & $3.60 \pm 0.26$ \\
\hline
\end{tabular}


Table S8. The mean fluorescence intensity ratio in NIH 3T3 cells after treated for $1 \mathrm{~h}$ via Dox-

$$
\text { loaded liposomes. }
$$

\begin{tabular}{|c|c|c|}
\hline entries & group & MFI ratio \\
\hline 1 & PBS & $0.19 \pm 0.02$ \\
\hline 2 & DPPC & 1 \\
\hline 3 & DDCP-a & $2.55 \pm 0.09$ \\
\hline 4 & DDCP-b & $2.49 \pm 0.07$ \\
\hline 5 & DDCP-c & $3.35 \pm 0.12$ \\
\hline 6 & DMCP-a & $1.35 \pm 0.06$ \\
\hline 7 & DMCP-b & $4.70 \pm 0.28$ \\
\hline 8 & DMCP-c & $0.94 \pm 0.02$ \\
\hline 9 & DPCP-a & $3.82 \pm 0.14$ \\
\hline 10 & DPCP-b & $2.99 \pm 0.10$ \\
\hline 11 & DPCP-c & $1.53 \pm 0.06$ \\
\hline 12 & Folate-CP & $1.22 \pm 0.09$ \\
\hline
\end{tabular}




\section{References}

[1] Perttu, E. K.; Kohli, A. G.; Szoka, F. C. J. Inverse-phosphocholine lipids: a remix of a common phospholipid. J. Am. Chem. Soc. 2012, 134, 4485-4488.

[2] Feng, Y.; Wang, G.; Chang, Y.; Cheng, Y.; Sun, B.; Wang, L.; Chen, C.; Zhang, H. Electron Compensation Effect Suppressed Silver Ion Release and Contributed Safety of Au@Ag Core-Shell Nanoparticles. Nano Lett. 2019, 19, 4478-4489.

[3] Cheng, Y.; Chang, Y.; Feng, Y.; Jian, H.; Tang, Z.; Zhang, H. Deep-Level Defect Enhanced Photothermal Performance of Bismuth Sulfide-Gold Heterojunction Nanorods for Photothermal Therapy of Cancer Guided by Computed Tomography Imaging. Angew. Chem. Int. Ed. 2018, 57, 246-251. 